\title{
Aykırı Vakıflar: \\ Osmanlıda Fukarâ-yı Müslimîni de Gözeten \\ Gayrimüslim Vakıfları*
}

Kenan Yıldız**

Unusual Foundations in the Ottoman Empire: Non-Muslim Waqfs and also those for "Poor Muslims"

Abstract - This work investigates fourteen non-Muslim (Christian and Jewish) waqfs and also those for "poor Muslims". In the literature this is the first work to shed light on "unusual waqfs" which are unusual among innumerable non-Muslim waqfs. Five of these waqfs are charitable, and the other nine ones are abli (family) waqf in type. The names of these waqf founders are as following: Âkile bt. Harun b. İbrahim (Jewish), Mansur b. Abdullah (Jewish), Gâliye bt. Sadun Kallâş (Jewish), Musa b. Davut b. Yakub (Jewish), Süleyman b. Davud (Jewish), Panayot veled-i [v.] Rafir (Greek), Semha bint-i [bt.] Musa (Jewish), Benyamin v. Musa (Jewish), Limon v. Yani (Greek), Halepli Sefer (Armenian), Sakyas v. Hacader v. Zirek (Armenian), Anica bt. Radul v. Angili (Greek), Mihail v. Toma (Greek) ve Nikolaki v. Şahin (Greek).

The work is divided into two parts. In the first part, the legal background which allowed foundations to be set up for non-Muslims will be given with regard to its basis in history. The place and development of these foundations in Islamic and Ottoman history will be summarized retrospectively. The ideas of Shaykh al-Islam Ebussuud Efendi, who shaped the legal framework of non-Muslim foundations, will be examined in this context. In the second part, fourteen waqfs in question will be examined and the copies of the related documents (waqf deeds) will be found

* Bu konu, 11-13 Mayıs 2018 tarihinde düzenlenen VI. Osmanlı İstanbulu Sempozyumu’nda tebliğ olarak sunulmuş ve tartışılmış, daha sonra genişletilerek makaleye dönüştürülmüştür. Çok değerli görüş, eleştiri ve katkılarını paylaşma lütfunda bulunan İsmail E. Erünsal, Mehmet Genç, Murat Çizakça, Yusuf bin İsmail, Bilgin Aydın, Mesut Sayan, Tommaso Stefini, Seyfi Kenan, Esra Muhacir, Nuray Güler, M. Âkif Aydın, Tahsin Hazırbulan, Ali Akyıldız, Kemal Beydilli, Mustafa Birol Ülker, Christopher Ferrard ve değerli katkılarından istifade ettiğim makale hakemlerine teşekkür ederim.

** İSAM. 
in facsimile form in an appendix. It has been hoped to arrive at the concept of a consensus for the perception of charity for the subjects of the Ottoman Empire, regardless of their religious identity.

Keywords: Endowment, Foundation, Family waqfs, Charity, The Poor, Non-Muslim (Christian and Jewish) waqfs, Church/Monastery waqfs, Haramayn waqfs (Waqf alHaramayn), The Poor of the Haramayn.

\section{Giriş}

Müslümanlar, Hıristiyanlar ve Yahudiler açısından sevap umulan dinî bir eylem olarak görülen vakıf kurma, genel anlamda "hayırseverlik" (charity/philantropy) kavramı ile karşılanan iyilikte bulunmanın bir yoluydu. Dinî, sosyal ve ekonomik hayatın merkezinde vakıflar bulunmaktaydı. Sınıfsal bir ayrıcalık gerektirmeyen vakıf kurmayı tetikleyen motivasyon ve kaygılar muhtelifti. ${ }^{1}$ Bunlar genel olarak, statü ve itibar elde etme, mülklerin istenilen kişi veya kurumların tasarrufuna bağlanması ve bu sayede istenmeyenlerin mahrum bırakılması; malın müsadere ve miras kıskacından kurtarılması ve bu yapılırken tamamen "ulvî" (exalted) bir amacın hedeflendiği gösterilerek hayırseverlik zaviyesinden sonraki hayatta (ahiret) korunma umulması şeklinde sıralanabilir. ${ }^{2}$ Diğer taraftan, vakıf kurmanın en temel motivasyon kaynağının "din" olduğu genel olarak kabul görmüştür. ${ }^{3}$

1 Vakıf kuranlarda aranan temel vasıflar şöyleydi: Hayır yapmaya muktedir olmak, malın tasarrufunu elinde bulundurmak, âkil olmak, hür olmak. Bkz. Ali Haydar, Tertîbü'l-Sunûf fî Ahkâmi'l-Vukûff(İstanbul: Şirket-i Mürettibiye Matbaası, 1337/1340), s. 121-2, 134.

2 Ö. Lütfi Barkan, "Şer’i Miras Hukuku ve Evlatlık Vakıflar," Türkiye'de Toprak Meselesi, haz. Abidin Nesimi, Mustafa Şahin, Abdullah Özkan (İstanbul: Gözlem Yayınları, 1980), s. 2118; Amy Singer, "Charity's Legacies: A Reconsideration of Ottoman Imperial EndowmentMaking," Poverty and Charity in Middle Eastern Contexts, ed. Michael Bonner, Mine Ener, Amy Singer (Albany: State University of New York Press, 2003), s. 298-9; Miriam Hoexter, "Waqf Studies in the Twentieth Century: The State of the Art," JESHO 41, no. 4 (1998), . 478-9; Mısır'da Eyyubiler döneminde Yahudilerin vakıf kurma gerekçeleri hakkında bir değerlendirme için bkz. Moshe Gil, Documents of the Jewish Pious Foundations from the Cairo Geniza (Leiden: Brill, 1976), s. 6-8, 12-13; Vakfın, İslâm tarihi boyunca devletin çıkarlarına karşı bir sistem olarak görülmesi bağlamında bir değerlendirme için bkz. Yaacov Lev, Charity, Endowments, and Charitable Institutions in Medieval Islam (Gainesville: University Press of Florida, 2005), s. 153-6.

3 Miriam Hoexter, "Charity, the Poor, and Distribution of Alms in Ottoman Algiers," Poverty and Charity in Middle Eastern Contexts, ed. Michael Bonner, Mine Ener, Amy Singer (Albany: State University of New York Press, 2003), s. 146-7; İnsanlık tarihi boyunca hayırseverliğin temel motivasyonu üzerine genel bir değerlendirme için bkz. Amy Singer, İyilik Yap Denize At: Müslüman Toplumlarda Hayırseverlik, çev. Ali Özdamar (İstanbul: Kitap Yayınevi, 2012), s. 13-45. 
Osmanlı vakıfları üzerine çok geniş bir literatür vardır. ${ }^{4}$ Fakat, bu araştırmaya konu edinilen aykırı gayrimüslim vakıfları, aşağıda yeri geldikçe atıf yapılacak olan söz konusu literatürde rastlanmayan bir olgudur. ${ }^{5}$ Aykırı gayrimüslim vakıflarının çoğu, genel yapıları itibariyle tipik aile vakfı olup sıradandırlar. Müslümanların, özellikle de Medine'de yaşayan Müslümanların lehine şart taşıyor olmaları ise bu vakıfları ve kurucularını aykırı sınıfına sokan asıl unsurdur. Aslında, Müslüman ve gayrimüslimlerin birbirlerinin fakirleri yararına vakıf kurmaları hukuken geçerli sayılıyordu. ${ }^{6}$ Yani, bir Müslüman gayrimüslim fukarayı kastederek; bir gayrimüslim de Müslüman fukarayı kastederek vakıf kurabilirdi. ${ }^{7}$ Ancak, literatürde bu tip vakıflara özel olarak değinilmemiş olması, konuyu ayrıcalıklı bir konuma taşımaktaydı. Söz konusu vakıfların mevcutlar içindeki yerlerinin daha iyi anlaşılabilmesi için gayrimüslim vakıflarının İslâm ve Osmanlı tarihindeki süreçleri öncelikli olarak işlenecektir. Devamında da, "aykırı" olarak tanımladığımız vakıflarla ilgili tespit edilen belgeler incelenecektir. ${ }^{8}$

4 Vakıflara dair çalışmaların bir kısmını derleyen ve önemli ayrıntılara dikkat çeken bir yayın için bkz . Hoexter, "Waqf Studies," 474-95.

5 Gayrimüslimler tarafından kurulan ve vakıftan yararlanacaklar arasında "bütün kaza sakinleri” manasında ifadeler kullanılması nedeniyle Müslümanları da kapsamış olan birkaç vakıf tespiti yapılmıştır. R. Shaham tarafından Yafa Şer'iyye Sicillerinden tespit edilmiş olan bazı vakıflar örnek verilebilir. 19. yüzyılda Yafảda yaşamış Ermeni keşiş Atnas el-Zeytünâlî (Yafa ŞS, 43, s. 109), Rum papaz Huri İbrahim v. el-Hâce Nikola v. el-Hâce Hana el-Bûrî (Yafa ŞS, 50, 4/8) ile Yahudi Maymon Amiel'in (Yafa ŞS, 47, s. 276) kurmuş oldukları aile vakıflarındaki şart silsilesi içinde, açıktan değilse de dolaylı olarak Müslümanlar da bulunmaktadır. Bkz. Ron Shaham, "Christian and Jewish Waqf in Palestine During the Late Ottoman Period," Bulletin of the School of Oriental and African Studies 104 (1991), s. 463, 468, 472; Bunlardan Lüd'de (Lydda, Lod) yaşayan İbrahim el-Bûrînin şart silsilesi şöyledir: Kudüs Rum-Ortodoks Manastırı keşişleri, Remle ve Lüd Rum-Ortodoks fukarası, Kudüs Rum Patrikhanesi fukarası, Şam Patrikhanesi fukarası, Halep fukarası, Kudüs fukarası ve nihai olarak da Kudüs Patrikhanesi'ne en yakın olanlardan başlayarak bütün fukara. Bu örneğin kısa bir değerlendirmesi için bkz. Hoexter, "Charity," s. 149.

6 Ali Himmet Berki, Vakıflar (İstanbul: Cihan Kitaphanesi, 1940), s. 65.

7 Hoexter, “Charity," s. 148'den naklen Muhammed Kadri Paşa, Kânûnül-adl ve'l-İnsâf li'lKazâ alâ Müşkilâti'l-Evkâf, 3rd ed., (Cairo: Bulaq, el-Matba'́ll-Kübrâ el-Emîriyye, 1902), md. 5; T. Tankut Soykan, Osmanlı Imparatorluğu'nda Gayrimüslimler: Klasik Dönem Osmanlı Hukukunda Gayrimüslimlerin Hukuki Statüsü (İstanbul: Ütopya Kitabevi, 2000), s. 124.

8 Sâir araştırmalarım sırasında birkaç tanesine rastladığım aykırı vakıf örneklerimi çoğaltmak ve çeşitliliği görebilmek amacıyla İstanbul Müftülüğü Şer’iyye Sicilleri Arşivi’ndeki 9885 defterde kayıtlı 9867 vakfiyenin indeksli kataloğu bütün olarak taranmıştır. Katalog için bkz. Bilgin Aydın, İlhami Yurdakul, Ayhan Işık, İsmail Kurt, Esra Yıldız, İstanbul Şer 'iyye Sicilleri Vakfiyeler Katalogu (Ankara: TDV - İSAM Yayınları 2015). Araştırmayı, Osmanlı 


\section{İslâm ve Osmanlı Tarihinde Gayrimüslim Vakıfları}

Kuruluş hedefleri' bakımından çeşitli olan vakıflar, hayrî ve ehlî olmak üzere iki türlüdür. Bu farklılaşma, vakıf kurucularının tercihlerine göre şekil alan bir durumdu. Hayrî vakıflar, doğrudan hayır maksadı taşıdıklarından bu şekilde anılmaktaydı. Doğrudan hayrı gözetmeyenler ise "ehlî/zürrî vakrf" veya "aile vakfi" olarak adlandırılmaktaydı $1{ }^{10}$ Vakıfların ontolojik varlık nedeni hayır yapmaktı. Bu bakımdan, vâkıfın nesli devam ettikçe mülk gibi tasarruf edilmeye devam eden aile vakıflarının hukuki durumu başlangıçta tartışmalı idi. ${ }^{11}$ Ancak, kurucularının veya vakıftan yararlananların nesilleri kesildikten sonra nihai ve zorunlu olarak hayrî vakfa dönüşecek olması ${ }^{12}$ dolayısıyla bu vakıflara İslâm tarihi boyunca hukuki bir engel çıarılmadı. ${ }^{13}$

coğrafyasının tamamını kapsayacak şekilde genişletmek, bu çalışmanın hacmini aşacağı gibi amacı da değildir.

9 Kişileri, vakıf kurmaya sevk eden muhtemel nedenlere değinen çalışmaları derli toplu şekilde inceleyen bir yayın için bkz. Pascale Ghazaleh, "Introduction: Pious Foundations: From Here to Eternity?," Held in Trust: Waqf in the Islamic World, ed. Pascale Ghazaleh (Cairo - New York: The American University in Cairo Press, 2011), s. 1-12.

10 Barkan, "Şer’i Miras Hukuku," s. 211-8; Ö. Lütfi Barkan - E. Hakkı Ayverdi, İstanbul Vakıfları Tahrîr Defteri (İstanbul: Baha Matbaası, 1970), s. XX-XXV; Aile vakıflarının hukukî kaideleri için bkz. Berki, Vakıflar, s. 92-105; İki özelliğe de sahip olanlar da "yarı-ailevî vakıf” olarak tanımlanmaktadır. Bkz. Bahaeddin Yediyıldız, XVIII. Yüzyılda Türkiye’de Vakıf Müessesesi: Bir Sosyal Tarih Incelemesi, (Ankara: TTK, 2003), s. 17-9.

11 Vakıf konusunu, hubs, zekât, sadaka, vasiyet, miras, hibe, hediye, hayırseverlik çerçevesinde tartışan ve vakfın İslâm fikhındaki köklerini ekoller açısından değerlendiren öncü çalışmalar için bkz. Fuad Köprülü, "Vakıf Müessesesinin Hukukî Mahiyeti ve Tarihî Tekâmülü," Vakıflar Dergisi II (1942), s. 1-35; Joseph Schacht, "Early Doctrines on Waqf," 60. Doğum Günü Münasebetiyle Fuad Köprülü Armăganı (Ankara: Dil ve Tarih Coğrafya Fakültesi, 1953), s. 443-52; Moshe Gil, “The Earliest Waqf Foundations," Journal of Near Eastern Studies 57, no. 2 (1998), s. 125-40; Randi Carolyn Deguilhem-Schoem, "History of Waqf and Case Studies from Damascus in Late Ottoman and French Mandatory Times," (PhD diss., New York University, 1986), s. 49-80; Norbert Oberauer, "Early Doctrines on Waqf Revisited: The Evolution of Islamic Endowment Law in the 2nd Century AH," Islamic Law and Society 20, no. 1-2 (2013), s. 1-47; Çok daha kapsamlı ve etkileyici bir sorgulama için bkz. Peter C. Hennigan, The Birth of a Legal Institution: The Formation of the Waqf in Third-Century A. H. Hanafí Legal Discourse (Leiden: Brill, 2004), s. 50-106; Murat Çizakça, İslam Dünyasında Vakıflar, çev. Elif Süreyya Genç (Konya: Karatay Üniversitesi Yayıncılık, 2017), s. 14-5.

12 Schacht, "Early Doctrines on Waqf," s. 446-51; John Robert Barnes, An Introduction to Religious Foundations in the Ottoman Empire (Leiden: Brill, 1986), s. 5-24.

13 Berki, Vakıflar, s. 65. 
Osmanlı İmparatorluğu’nda gayrimüslimler, kendilerine tanınan haklar çerçevesinde ehlî ve hayrî birçok vakıf kurdular. ${ }^{14}$ Ehlî vakıf kurmak, her din mensubu için genel bir hak idi fakat, gayrimüslimlerin hayrî vakıf kurmaları, şekil olarak farklı kurallara tabiydi. Gayrimüslimler kendi kilise ve manastırlarına doğrudan vakıf kurma hakkına sahip değillerdi. ${ }^{15}$ Bu kurumlar vakfiyelerde dolaylı şekilde zikredilmeli, vakıflardan asıl faydalanacak kimselerin fakirler $(\text { fukarâ })^{16}$ olduğu mutlaka belirtilmeliydi. Buna göre gayrimüslim vakıfları, Hıristiyan ve Yahudilerin mabetlerini temsil eden ortak bir terim olan "kilise"ye değil, "kiliseye gelen giden fukarâya” şart edilmeliydi. Fıkhın, hayrî vakıf bağlamında gayrimüslim vakıfları için öngördüğ̈̈ şart buydu. Osmanlıda gayrimüslimler tarafından kurulmuş olan diğer vakıfların şartlarına bakıldığında "fukarâ" ibaresinin ön planda olduğu görülmektedir. Bu durum, yukarıda değinilen ilkenin uygulamadaki bir yansımasıydı. ${ }^{17}$

14 Ankara Vakıflar Genel Müdürlüğü Arşivi’nde kayıtlı 27.000'den fazla vakfiye kaydı mevcuttur. Bkz. Hasan Yüksel, "Vakfiye: Türk ve Osmanlı Tarihi," Türkiye Diyanet Vakfı Íslâm Ansiklopedisi, 2012, XLII, s. 468; İstanbul sicillerinde tespit edilen vakfiyelerin sayıs1 9.872'dir. Bkz. Aydın ve dğr., Vakfiyeler Katalogu, s. 15.

151530 yılına ait bir Rumeli Muhasebe defterinde "Evkâf-ı Manastır ve Kenâyis” başlığı altında yer alan 13 manastır ve 54 kilisede toplam 93 ruhban bulunduğu kaydedilmiştir. Ali Coşkun ve dğr. (yay. haz.) 167 Numaralı Muhâsebe-i Vilâyet-i Rûm-İli Defteri (937 / 1530) (Ankara: Devlet Arşivleri Genel Müdürlügü Yay., 2003), I, s. 19; Yukarıdaki genel kurala göre bu örnek istisnai durmaktadır. Konu hakkında değerlendirme ve bazı örnekler için bkz. Elias Kolovos, "Christian Vakifs of Monasteries in the Ottoman Greek Lands from the Fourteenth to Eighteenth Centuries," Les Fondations pieuses waqfs chez les chrétiens et les juifs: Du Moyen Âge à nos jours, ed. Sabine Mohasseb Saliba (Paris: Geuthner, 2016), s. 108-10.

16 Terim olarak "fakir", "omurgası, belkemiği kırılmış kimse"; kelime olarak ise, "başkasına muhtaç olan kimse” demektir. Ayrıntılı açıklama ve değerlendirmeler için bkz. Berki, Vakıflar, s. 106-10; Osman Eskicioğlu, "Fakir," Türkiye Diyanet Vakfı İlâm Ansiklopedisi, 1995, XII, s. 129-31; Adam Sabra, Poverty and Charity in Medieval Islam: Memluk Egypt, 1250-1517 (Cambridge: Cambridge University Press, 2000), s. 8-31; Hoexter, “Charity," s. 148-51; Eyal Ginio, "Living on the Margins of Charity: Coping with Poverty in an Ottoman Provincial City," Poverty and Charity in Middle Eastern Contexts, ed. Michael Bonner, Mine Ener, Amy Singer (Albany: State University of New York Press, 2003), s. 167; Michael Bonner, "Definitions of Poverty and the Rise of the Muslim Urban Poor," Journal of the Royal Asiatic Society Third Series 6, no. 3 (1996), s. 335-344; Fakirlik ve miskinlik üzerine incelikle işlenmiş tarihsel bir değerlendirme için bkz. Singer, İilik Yap Denize At, s. 198-237; M. Cohen de, Geniza kayıtları üzerinden Ortaçağ'da Yahudilerde vakıf, fakirlik ve hayırseverliği incelemiştir. Bkz. Mark R. Cohen, Poverty and Charity in the Jewish Community of Medieval Egypt (Princeton: Princeton University Press, 2005).

17 Gayrimüslim vakıfları ağırlıklı olarak "kilise fukarası", "Nasârâ fukarası", "Ermeni fukarası" ve "hastane fukarası" yararına kurulmaktaydı. Örneğin Kürkçü Acı Hristo v. Yamandi, Sakız, 
Gayrimüslimler, Osmanlı döneminde avarız vergilerinin karşılanması ${ }^{18}$ veya Kudüs ${ }^{19}$ için de vakıflar kurmuşlardı. ${ }^{20}$ Bunun dışında ehlî vakıflar da İslâm tarihi boyunca yaygınlık kazanmış bir vakıf türüydü. ${ }^{21}$

Gayrimüslim aile vakıflarının ilk örnekleri, Kudüs'ün fethi sonrasında buradaki Yahudi ve Hıristiyanlara ait mabetler (kilise) ${ }^{22}$ için yapılan vakıf ve bağışlarda görülmektedir. ${ }^{23}$ Miladi 800 yılı itibariyle Tunus Kayrevan'da Yahudiler tarafından eğitim amaçlı ve fukaranın bakımı için kurulmuş vakıflar mevcuttu. ${ }^{24}$ Ortaçağ ve sonraki dönemler boyunca Müslüman devletlerin himayesindeki Yahudilerin kendi

Edirne, Bursa, Yedikule ve daha birçok yerde "Nasarâ fukarasına taamiye" ve "Panaya Kilisesi fukarasına” şartlarını öngören para vakıfları kurmuştur. Bkz. Aydın ve dğr., Vakfiyeler Katalogu, 44-45. Belgeler için bkz. İstanbul ŞS, 91, 51b-54a (21 R 1221/9 Temmuz 1806); İŞS, 96, $11 b$ (10 Ş 1223/1 Ekim 1808); 114, 10b-12a (19 Ra 1230/1 Mart 1815); İncil öğretmesi için fakir papaza Lefter v. Yivan isimli bir Rum 1200 kuruş ve kilise fukarasına Artin v. Atam 1000 kuruş vakfetmişlerdir. Bkz. Aydın ve dğr., Vakfiyeler Katalogu, s. 83, 88. Belgeler için bkz. Bab ŞS, 195, 13a (19 Ş 1161/14 Ağustos 1748); Bab ŞS, 278, 59a-b (26 L 1195/15 Ekim 1781).

18 Örneğin İrine bt. Yorgi v. Kosti evini, Mıgırdıç v. Minnas da 1250 kuruşunu zimmî ve kilise avarızına vakfetmişlerdir. Bkz. Aydın ve dğr., Vakfiyeler Katalogu, s. 72, 89. Belgeler için bkz. Bab ŞS, 95, 4a (9 Ş 1122/3 Ekim 1710); Bab ŞS, 284, 76b-77a (3 M 1198/28 Kasım 1883).

19 Örneğin Nesaneyil v. Anton Kudüs’te kilise fukarasına 20.000 kuruş vakfetmiştir. Bkz. Aydın ve dğr., Vakfiyeler Katalogu, s. 45. Belge için bkz. İstanbul ŞS, 95, 29b (22 M 1223/20 Mart 1808).

20 Abraham Marcus, Osmanlı'da gayrimüslimlerin vakıf kurma amaçları hakkında çok önemli bir tespitte bulunmaktadır: "Hristiyanların ve Yahudilerin fakirlere yardım konusuna farklı şekilde yaklaşması, bu grupların geçmişe dayanan sıkı cemaat yapılanmasıyla olduğu kadar azınlık gruplar olarak yaşadıkları emniyetsizlik hissiyle de alakalıydı. Cemaatleri için en büyük tehdit olan Müslümanlığı seçme eyleminin, zimmi konumunun maddi yükümlülüklerinden kurtulmak isteyen biçare fakirleri etki altında bıraktığını yaşadıkları tecrübelerden öğrenmişlerdi.” Bkz. Abraham Marcus, Modernliğin Eş̧̌̆ginde Bir Osmanlı Şehri: Halep, çev. Mehmet Emin Baş (Küre Yayınları: İstanbul 2013), s. 280-1.

21 Lev, Charity, s. 66, 153.

22 "Kilise/Kenîse" (çoğulu "kenâis"), Osmanlı'da hem Hıristiyan hem de Yahudilerin mabetlerini tanımlayan ortak bir anlama sahipti. Bkz. Sir James W. Redhouse, A Turkish and English Lexicon, 2. bs., (Beirut: Librairie du Liban, Beirut 1987), s. 1578.

23 Moshe Gil, fetih sonrasında Kudüs'teki manastır, kilise ve sinagoglar için yapılan bağış ve vakıfları incelemiştir. Bkz. Moshe Gil, "Dhimmi Donations and Foundations for Jerusalem (638-1099),” JESHO 27, no. 2 (1984), s. 156-74.

24 Lev, Charity, 66'dan naklen Menahem Ben-Sasson, The Emergence of the Local Jewish Community in the Muslim World: Qayrawan, 800-1057 (Jerusalem, 1996, s. 183-6) (İbranice). 
vakıflarını (qodesh, heqdesh) kurmaya devam ettikleri bilinmektedir. ${ }^{25}$ Örneğin, Geniza belgeleri üzerinden 10-13. yüzyıl Kahire'sinde Yahudi toplumunun sosyal ilişkilerini inceleyen S. D. Goitein çığır açan eserinde, birçok Yahudi vakfının varlığı ve işleyişi hakkında çok değerli bilgiler vermektedir. ${ }^{26}$ Bir kısmı aile vakfı olarak teşekkül etmiş olan bu vakıflar gıda temini, giyim, barınma, cizye ödemeleri, sağlık, eğitim, para yardımı, cenaze masrafları, yolculara yardım, fakir ve hastaların bakımı, savaş esirlerinin fidyelerinin temini ve âlimlerin desteklenmesi gibi farklı amaçlarla kurulmuştu. ${ }^{27}$

Hıristiyanların kurdukları vakıflar da İslâm tarihinin erken dönemlerine gitmektedir. ${ }^{28}$ Hıristiyanlara ait aile vakıflarının ilk örneğine 1393 yılında Memlükler

25 Kahire'de 1024-1865 yılları arasında Karaim Yahudileri tarafından kendi cemaatleri yararına kurulmuş olan vakıflar için bkz. D. S. Richards, "Arabic Documents from the Karaite Community in Cairo," JESHO 15, no. 1/2 (1972), s. 105-162; Mark Cohen, Ortaçağ Kahire'sinde Yahudi vakıflarını Geniza kayıtları üzerinden çok yetkin bir şekilde incelemektedir. Bkz. Cohen, Poverty and Charity, (heqdesh için bkz. 200-204); 19. yüzyıl Osmanlı Yahudi vakıfları üzerine bir çalışma için bkz. Yaron Ayalon, "Poor Relief in Ottoman Jewish Communities," Jews, Christians and Muslims in Medieval and Early Modern Times: A Festschrift in Honor of Mark R. Cohen, ed. Arnold E. Franklin, Roxani Eleni Margariti, Marina Rustow, Uriel Simonsohn (Leiden: Brill, 2014), s. 67-82; Yahudi cemaatlerinin her türlü sosyal ve ekonomik faaliyetlerini finanse eden, bir sosyal yardımlaşma ve dayanışma kurumu olarak Yahudi hukukuna göre teşekkül etmiş bulunan "heqdesh" hakkında bilgi için bkz. Gil, Documents, s. 1, 4, 5, 19; Miriam Frenkel, “'From Now on it is Heqdesh': Jewish Pious Foundation in the Medieval Lands of Islam," Les Fondations pieuses waqfs chez les chrétiens et les juifs: Du Moyen Âge à nos jours, ed. Sabine Mohasseb Saliba (Paris: Geuthner, 2016), s. 85-99; Hennigan, The Birth of, s. 57-8.

26 S. D. Goitein, A Mediterranean Society: The Jewish Communities of the Arab World as Portrayed in the Documents of the Cairo Geniza, (Berkeley: University of California, 1971), vol. 2, s. 112-43; Hayırseverliğin Geniza toplumundaki yansımaları ve toplumsal ilişkilere etkisi üzerinden incelendiği önemli bir çalışma için bkz. Miriam Frenkel, "Charity in Jewish Society of the Medieval Mediterranean World," Charity and Giving in Monotheistic Religions, ed. Miriam Frenkel, Yaacov Lev (Berlin: Walter de Gruyter, 2009), s. 343-64.

27 Goitein, A Mediterranean Society, vol. 2, s. 126-38; Lev, Charity, s. 66; Geniza toplumunda hayırseverlik örnekleri için bkz. Mark R. Cohen, "Geniza Documents for the Comparative History of Poverty and Charity," Charity and Giving in Monotheistic Religions, ed. Miriam Frenkel, Yaacov Lev (Berlin: Walter de Gruyter, 2009), s. 283-341.

28 İslâm öncesi ve erken İslâm döneminde Ortadoğu'daki Hıristiyan vakıfları hakkında detaylı bilgi için bkz. Johannes Pahlitzsch, "Christian Pious Foundations as an Element of Continuity Between Late Antiquity and Islam," Charity and Giving in Monotheistic Religions, ed. Miriam Frenkel, Yaacov Lev (Berlin: Walter de Gruyter, 2009), s. 125-51. 
dönemi Kahire'sinde rastlanmaktadır. ${ }^{29}$ Aynı devirlerde Bizans'ta da mevcut olan kilise/manastır vakıflarının ${ }^{30}$ İslâm tarihindeki tespit edilen ilk örneği de Malik b. Hubara isimli bir Hıristiyan'ın, Tur Dağı'nda bulunan St. Catherine Manastırı için 1197'de kurduğu vakıftır. ${ }^{31}$ Malik bunun dışında, malının bir kısmını da ailesine vasiyet etmişti. ${ }^{32} \mathrm{Bu}$ bakımdan, hem ehlî hem de hayrî bir nitelik taşıması, bu vakfın diğer bir özelliği olarak zikredilmelidir. Vakfın hayrı amaçlayan en önemli ilkesi, önceki devirlerde olduğu gibi, ${ }^{33}$ Osmanlı dönemindeki gayrimüslimler (zimmîler) ${ }^{34}$ tarafından da benimsendi.

Gayrimüslim vakıfları Osmanlılar tarafından da önemli bir hukuki mesele olarak tartışılmıştır. Bu konudaki hukuki arka plan, 16. yüzyılın ikinci yarısına kadar oldukça kısıtlayıcı bir yapıya sahipti. Gayrimüslim tebaa dışında rahip ve keşişlerin manastır ve kiliseleri için vakıf kurmaları konusunda bir belirsizlik hatta muhalefet söz konusuydu. Bu nedenle, II. Selim döneminde Rumeli'de birçok manastır vakfı, hazineye gelir sağlamak üzere müsadere edilmiş ve akabinde satılmışt. ${ }^{35}$ Zira söz konusu vakıflar, doğrudan dinî eğitim ve hizmeti amaçlayan özelliğe sahiplerdi. ${ }^{36}$

29 Pahlitzsch, "Christian Waqf in the Early and Classical Islamic Period (Seventh to Twelfth Centuries)," Les Fondations pieuses waqfs chez les chrétiens et les juifs: Du Moyen Âge à nos jours, ed. Sabine Mohasseb Saliba (Paris: Geuthner, 2016), s. 36.

30 Vakıf kurumunun Roma/Bizans kökleri üzerine toparlayıcı bir çalışma için bkz. Murat Çizakça, "Philanthropic Foundations in Roman/Byzantine and Ottoman Empires: A Study in Continuity and Change," Festschrift for Olga Katsiardi (yayınlanacak); Bizans'tan Osmanlı'ya intikal eden ve korunan manastır vakıfları için bkz. Kolovos, "Christian Vakıfs," s. 103-27.

31 Donald S. Richards, "Some Muslim and Christian Documents from Sinai Concerning Christian Property," Law, Christianity and Modernism in Islamic Society. Proceedings of the Eighteenth Congress of the Union Européenne des Arabisants et Islamisants, ed. U. Vermeulen, J. M. F. Van Reeth , (Leuven: Uitgeverij Peeters, 1998), s. 161; Pahlitzsch, "Christian Waqf," s. 44-6.

32 Richards, "Some Muslim," s. 161.

33 Gil, Documents, s. 8-11; Lev, Charity, s. 66-7; Eskiçağlar boyunca Yahudi ve Hiristiyanlarda hayırseverlik üzerine bir çalışma için bkz. Frederick B. Bird, "A Comparative Study of the Work of Charity in Christianity and Judaism," Journal of Religious Ethics 10, no. 1 (1982), s. 144-69.

34 İslâm ülkesinde devletin güvencesi altında yaşayan gayrimüslimler. Ayrıntı için bkz. Mustafa Fayda, Ahmet Yaman, M. Macit Kenanoğlu, "Zimmî," Türkiye Diyanet Vakfı Ílâm Ansiklopedisi, 2013, XLIV, s. 428-40; Gülnihal Bozkurt, "İslam Hukukunda Zimmilerin Hukuki Statüleri,” Dokuz Eylül Üniversitesi Hukuk Fakültesi Dergisi 3 no. 1-4 (1987), s. 115-55.

35 A. Fotic'in makalesi bu konuyu işlemektedir: "The Official Explanations for the Confiscation and Sale of Monasteries (churches) and their Estates at the Time of Selim II," Turcica 24 (1994), s. 33-54.

36 Fotic, "The Official Explanations," s. 42-43. 
Gayrimüslimlerin kurdukları vakıflarda dinî bir amaç gözettiklerini açık şekilde belirtmeleri, geleneksel İslâm fikhına göre mümkün değildi. Fakat, gayrimüslimlerin vakıf kurma istek ve ihtiyaçlarına da bir cevap verilmesi gerekmekteydi. Gayrimüslim vakıfları bağlamındaki mevcut belirsizlik, para vakıfları, toprak hukuku ${ }^{37}$ gibi İmparatorluk açısından en temel ve tartışmalı meseleler üzerinde hukuki ve kanuni düzenlemeler yapmış bulunan Şeyhülislâm Ebussuud'un çözümleyici fetvaları ile II. Selim döneminde tartışmalı bir yapıdan kurtarılarak, aşă̆ıda incelenecek olan fikıh kuralları temelinde, sağlam bir yapıya kavuşturuldu. Ebussuud'un fetvaları ile kanuni ve hukuki bir temel oluşturularak gayrimüslim vakıflarına bir meşruiyet alanı açılmış oldu. ${ }^{38}$ Böylece, Osmanlı idaresi altında birçok gayrimüslim vakfı bu kurallar dairesinde varlık kazanabildi. ${ }^{39}$

\section{Gayrimüslim Vakıfları: Teorik Arka Plan}

Gayrimüslim vakıfları başlangıçta "vakıf” kavramı dışında tartışıldı. Bunun yerine "vasiyet" ve "miras" olgusu üzerinden "kurbet" (meşru) ve "masiyet" (gayrımeşru) bağlamları esas alındı. Hicri 2-3 / Miladi 8-9. yüzyıllarda yaşamış olan el-Hassaf, gayrimüslim vakıflarının meşru sayılmasının kaidesini belirlerken söz konusu kavramları şu şekilde açıklamıştı: 'Íslâm hukukuna göre, bir Hıristiyan veya Yahudi Kudüsteki Beyt-i Makdis yararna vakıf kurabilirdi. Bu durum Kudüsün her iki din için kutsal olmasından kaynaklanmaktaydı. Ancak, bir Mecusi ayn amaçla vakıf kuramazdı. Bu da Kudüs'ün bir Mecusi açısından kutsiyet ifade etmemesinden ileri gelmekteydi. . ${ }^{40}$ Buna göre, kurulan vakfın "kurbet" veya "masiyet" teşkil edip etmediği, vakfı kuran kişinin dinine göre anlaşılabilirdi. ${ }^{41}$ Bu örnek, mevzubahis olan dinlerin akidelerine saygı ifade eden temel bir kaide olarak sonra gelen fakihler için de ilkesel bir işlev gördü.

37 Ebussuud'un Üsküp, Selânik ve Budin'de vakıf ve mîrî arazi kanunnamelerine dair bir değerlendirme için bkz. Barnes, An Introduction, s. 32-39.

38 Eugenia Kermeli, "Ebû̀s-Su ûd'a Göre Kilise Vakıfları: Osmanlı Hukukundaki Teori ve Pratiği," çev. Özgen Özcan, Vakıflar Dergisi 34 (2010), s. 169-75.

39 Kolovos, "Christian Vakıfs," s. 110-11; Berki, Vakıflar, s. 65.

40 Pahlitzsch, "Christian Waqf," s. 35; Konu hakkındaki fikhi yorumların kısa bir özeti için bkz. Hoexter, "Charity," s. 146.

41 “İmâm A’zam’ın delîli şudur: Mu’teber olan, onların hakkında diyânetleridir. Çünkü biz, onları diyânetleri ile başbaşa bırakmakla emr olunduk. Bu vasiyyet, onlara göre kurbettir. Şu hâlde sahîh olur.” Bkz. Molla Hüsrev, Gurer ve Dürer Tercümesi: İslâm Fıkhı ve Hukûku, çev. Arif Erkan (İstanbul: Eser Neşriyat, 1980), c. IV, s. 400. 
Nitekim, Molla Hüsrev (ö. 1480) de, bir gayrimüslimin fakirlere, köle azat etmeye veya Beyt-i Makdis'e kandil yakmaya vasiyet etmesini kendi inancı açısından meşru yani "kurbet" olarak değerlendirmekteydi:

"Malının üçte birini fakîrlere veyâ köle âzâd etmeye yâhûd Beyt-i Makdis'de (Mescid-i Aksẩda) kandil yakmaya vasiyyet etmesi böyledir. Bu vasiyyet, ittifâkla sahîh olur. Çünkü diyânette hepsi ittifâk etmişlerdir. Yâhûd vasiyyet onlara göre, kurbet; bize göre, ma’siyettir. Meselâ hânesini Yahûdîler için havra, Hıristiyanlar için kilise, vayâ Mecûsîler için âteşgede yapması böyledir. Bu vasiyyet mutlakâ sahîh olur. Yânî gerek kendileri için vasiyyet ettiği topluluğu belirtsin, gerekse belirtmesin fark etmez. İmâmeyn'e göre; ancak belli kimseler için vasiyyet ederse, sahîh olur. ... İmâm A’zam'ın delîli şudur: Mưteber olan, onların hakkında diyânetleridir. Çünkü biz, onları diyânetleri ile başbaşa bırakmakla emr olunduk. Bu vasiyyet, onlara göre kurbettir. Şu hâlde sahîh olur. "²

Bu yoruma göre bir gayrimüslimin, mescit yapılmasını veya mescitlerde kandil yakılmasını vasiyet etmesi geçerli olamazdı. Ancak, belli bir gruba yapılması halinde vasiyet hukuki bir bağlam kazanabilirdi. ${ }^{43}$ Bütün bu tartışmalar, gayrimüslimlerin vakıf kurma, kendilerinden sonra mallarının tasarrufunu diledikleri kimseye bırakabilme iradelerine hukuki bir çerçeve kazandırmayı amaçlamaktaydı.

Molla Hüsrev'in meşru bir zemin bulmaya çalıştığı bu konu etrafında tartışmalar olmuş, fikirler ileri sürülmüştü. Zira, Rumeli'de “yüzyzllar boyunca, özellikle İstanbul'un fethinden önce, Balkanlarda nüfuz sahibi manastrr cemaatleri, bölgedeki en güçlü toprak sahipleri arasındaydi". ${ }^{44}$ Ancak, Ebussuud'a kadar bu tür vakıfların hukuki çerçevesi tam olarak belirlenemedi. ${ }^{45}$ Mevcut kısıtlayıcı zemin, Ebussuud tarafından klasik hukukun bir yorumu olarak çok teknik biçimde belirgin ve kapsayıcı bir hale getirildi. Vakfiye şartları arasına kiliselerin menfaatini açıkça gösteren bir madde eklenmesi, ilgili vakfı hayrî vakıf kategorisine taşıyacak olması fıkıh açısından mahzurluydu. Bundan dolayı, vakıf şartlarının dolaylı şekilde

42 Molla Hüsrev, Gurer ve Dürer, c. IV, s. 400-1.

43 "vasiyyet, onlardan muayyen bir kavme olursa, bu takdîrde onlara temlîk olması bakımından sahîh” sayılırdı. Bkz. Molla Hüsrev, Gurer ve Dürer, c. IV, s. 400; Gayrimüslim vakıfları konusunda bir değerlendirme için bkz. Soykan, Gayrimüslimler, s. 123-7.

44 Kermeli, "Ebû’s-Su'ûd'a Göre Kilise Vakıfları," s. 166.

45 Gayrimüslim vakıfları hakkında hukuki tartışmaları değerlendiren önemli bir çalışma için bkz. Eugenia Kermeli, “Erken Dönem Osmanlı Hukuku ve Gayri Müslimler,” Uluslararası Molla Hüsrev Sempozyumu (18-20 Kasım 2011, Bursa) -Bildiriler-, ed. Tevfik Yücedoğru vd. (Bursa: 2013), s. 431-47. 
"fukarâ" ibaresi üzerinden belirlenmesi ve vakfin ehlî vakıf kategorisinde kurulması gerekmekteydi. Manastır/kiliseyi gözeten bir vakıf kurulması isteniyorsa, bunun dışında bir yol yoktu. Ebussuud, gayrimüslim vakıflarının, tamamen şeklî bir yapıya sahip olan bu şarta uygun kurulmaları halinde varlıkları için hukuki bir koruma sağlanmış olacağını en yetkili hukuk otoritesi olarak beyan etmekteydi. Ebussuud'un verdiği iki fetva şöyleydi:

\section{Fetva-1}

"Mes'ele: Zeyd-i zimmî mülk evini kiliseye, ba’dehu kilise harab oldukta fukaraya vakf edip, hâkim dahi mezkûr evin vakfiyetini kabul edip hüccet vermek şer’an câiz olur mu?

Elcevap: Kiliseye vakıf bâtıldır. Amma sâkinlerine vakf edip anlardan sonra sâir fukarâya şart etmek şer'îdir." ${ }^{46}$

\section{Fetva-2}

“Mes'ele: Ba’zı zimmîler bir manastır râhibleri olduklarında, mezburların ellerinde olan mülk davarların ve bağların ve bahçelerin ve değirmenlerin il kâtibi mezburların ellerinden alıp, yine mezburlara bey’ edip, mezbur zikr olunan emlâki mezbur manastırın fukarâsına ve âyende ve revendesine vakf eylese, ba’de zamânin mezbur vakfa şer'an hâriçten kimse dahle kâdir olur mu?

Elcevap: Vakf ettikleri davar ve bağ ve bahçe değirmen ve dükkân makûlesinden olup, manastıra vakf etmeyip, gelen giden fukaraya vakf edicek aslâ dahl olunmaz. Tarlalar ve mezra’lar ise asla vakfa kâbil değildir. Amma anı dahi mîrîden tapuya alıp "râhibler tasarruf edip sâir re’âyâ gibi cemi' hukûkunu verdikten sonra kimse dahl etmeye. Rahipler fevt oldukta, yerinde kalanlar tasarruf edeler" deyu defterde kayd olunucak ana dahl olunmaz, vakıf adına olmayıcak." ${ }^{47}$

Manastırlar yarımadası olan Aynoroz’a dair çıkarılan 13 Şaban 976 / 31 Ocak 1569 tarihli emir bu bağlamda bir milat teşkil etti. ${ }^{48}$ Ebussuud'un fetvası Aynoroz'daki manastırlarda yaşayan rahiplere ait mülklerin, diğer rahiplere miras olarak geçmesi konusundaydı. Öte yandan İmam-1 Azam’a göre miras, vakıf kapsamında (vakıf menzilesinde) sayılıyordu. ${ }^{49} \mathrm{Bu}$ bağlamda, nötral bir içerik taşıyan "fukarâ"

46 M. Ertuğrul Düzdă̆, Şeyhülislâm Ebussû̂d Efendi Fetvaları: Kanunî Devrinde Osmanlı Hayatı (İstanbul: Gonca Yay., 2009), s. 156.

47 Düzdağ, Ebussuîd Efendi Fetvalar, s. 151.

48 Barnes, An Introduction, s. 35-6.

49 Molla Hüsrev, Gurer ve Dürer, c. IV, s. 400. 
ibaresi, iki fetvada görüldüğü üzere, kilise ve manastır vakıflarının kurulabilmesi için bir anahtar kavram olarak Ebussuud tarafından öne çıkarıldı..$^{50}$

II. Selim’in, Patmos adasındaki manastır vakıflarının müsadere edilmesi konusuna dair 6 Cemaziyelahir 977 / 17 Kasım 1569 tarihli fermanında yer alan benzer bir başka fetvasında da Ebussuud, rahip ve keşişlerin vasiyetlerini birtakım şartlara bağlayarak kuralları ana hatları ile belirginleştirdi. Gayrimüslimlerin vakıf kurabilmelerine imkân tanıyan şartlar, vasiyet/miras bağlamında şu şekilde açıklandı:

Fetva-3

"Mes'ele: Bir manastırın keşişleri, mîrî tarafından satın aldıkları bağı ve evi ve yeri kendilerden sonra mezbûr manastırda sâkin olan keşişlere vasiyet etmeleri câiz olur mu?

Elcevap: Vârisler yok ise, yerlerden gayri cemî̀ emlâklerin manastırlarında sâkin keşişlere vasiyet eyleseler, ol keşişler mahsûr ve muayyen kimseler ise, ganîler ise dahi fakirler ise dahi vasiyetleri sahihtir. Aslâ mîrîden kimse dahl edemez. Amma mahsûr olmayıp, çokluk tâife ise, anların cümlesine vasiyet etmek sahih değildir. Fakirlerine vasiyet etmek gerektir ki, asla kimse dahl edemeye..." ${ }^{\text {51 }}$

Sonuç olarak Ebussuud, gayrimüslimlerin kilise ve manastır için vakıf kurmaları konusu üzerinde var olan açmazları hukuki bir hile ile ortadan kaldırmış olmakta, özellikle yukarıdaki ikinci fetvada geçen "manastıra vakf etmeyip, gelen giden fukarâya vakf edicek aslâ dabl olunmaz" şeklinde belirlediği kaide ile probleme teknik çözüm getirmekteydi. ${ }^{52}$ Böylece, dinî amaç taşıyan gayrimüslim vakıfları, ehlî vakıf / aile vakfı kanalıyla vasiyet ve miras istikametinde gelişerek sağlam bir kurumsal kimliğe kavuşturuldu.

Ebussuud, gayrimüslim vakıfları hakkındaki fikhi kuralı ilan ederken, Hanefi fikhının İmam-ı Azam'dan sonraki en önemli iki hukukçusundan biri olan ve ehlî vakıfların kurulabilmesine onay veren İmam Ebu Yusuf'tan ilham almış olmalıdır. ${ }^{33}$ Vakıftan yararlananların nesillerinin kesilmesi sonrasında kaçınılmaz

50 Fermanın önemli bir bölümü üzerinden konunun etraflı bir şekilde incelendiği çalışma için bkz. Kermeli, "Ebû̀s-Su'ûd'a Göre Kilise Vakıfları," s. 172-4; Ayrıca bkz. Ahmet Akgündüz, İlâm Hukukunda ve Osmanlı Tatbikatında VakıfMüessesesi, 2. bs. (İstanbul: OSAV, 1996), s. 238-41; Colin Imber, Şeriattan Kanuna: Ebussuud ve Osmanlida İslami Hukuk, çev. Murteza Bedir (İstanbul: Tarih Vakfi Yurt Yay., 2004), s. 171-3.

51 Düzdağ, Ebussuîd Efendi Fetvaları, s. 150-1.

52 Düzdağ, Ebussuîd Efendi Fetvalar, s. 151.

53 Kermeli, “Ebû̀s-Su'ûd'a Göre Kilise Vakıfları,” s. 166. 
olarak fukaraya tahsis edilecek olmasından dolayı Ebu Yusuf aile vakıflarına onay vermişti.

Gayrimüslimler, Osmanlı tarihi boyunca hukuk sınırları dahilinde kalmaya ve manastırlara açıktan vakıf kurmamaya dikkat etmişlerdir. ${ }^{54}$ Ancak, bazen doğrudan manastırlara, bazen de keşişlere vakıflar kurulmuş olmasına dair tespit edilen istisnai örnekler, Ebussuud'un vaz ettiği kurallara zaman zaman aykırı hareket edildiğini de göstermektedir. ${ }^{55}$ Örneğin, 1623 yılında Kesendire’de Yorgo İkşirohorit isimli bir zimmi, kendisine ait arazi ve değirmeni doğrudan Athonite Manastır’na vakfettiğini ifade etmiş, Kesendire kadısı da vakfı onaylamıştır. ${ }^{56}$ Tabii, kanunen geçersiz olması gereken bu tür vakıflardan müsadere edilenler olmuştur. ${ }^{57}$

17. yüzyıl başı ve 18. yüzyıl sonuna kadar olan geniş bir dönem içerisinde kurulmuş bazı kilise vakıfları, geçerli hukukun dışında bir başka yolun daha izlenmiş olduğunu düşündürmektedir. Zira, belirtilen dönemde Rumlara ait bazı bölgelerde manastırlara yapılan bağışların Roma-Bizans hukukuna dayalı olarak devam ettiğini gösteren örnekler vardır. ${ }^{58} \mathrm{~S}$. Laiou'nun tespitlerine göre, Sisam adasındaki manastır arşivlerinde de 17-18. yüzyıllara ait toplam 172 Rumca vakfiye bulunmaktadır. Kadı onayı taşımadığından bu vakfiyelerin Osmanlı hukuku nezdinde resmî bir karşıllğ̆ yoktu. Laiou bu tespiti yaptıktan sonra, diğer manastır arşivlerinde de benzer nitelikte belgelerin bulunduğunu ifade etmekte ve bunlar üzerine yapılacak araştırmaların, kilise/manastır vakıfları bağlamında Osmanlı hukuku dışında uygulanmış ikinci bir hukukun varlığının sınırlarını bilmemize yardım edeceğini söylemektedir. ${ }^{59}$ Elias Kolovos da, kilise/manastır vakıfları bağlamında görünen

54 S. Laiou, bu durumu Midilli ve Teselya'dan iki manastır örneği ile açıklamaktadır. Bkz. Sophia Laiou, "Diverging Realities of a Christian Vakıf, Sixteenth to Eighteenth Centuries," Turkish Historical Review 3 (2012), s. 12.

55 Kolovos, "Christian Vakıfs," s. 114-5; Laiou, "Diverging Realities," s. 14, 16-17; Yafa'da bazı gayrimüslimler doğrudan keşişlere vakıf kurmuşlardır. Bkz. Shaham, "Christian and Jewish Waqf," s. 462.

56 Kolovos, "Christian Vakıfs," s. 113. Kolovos, bu belgeyi Aynoroz'daki Xeropotamou Manast1r1 Arşivi'nde yaptığı bir araştırmada tespit etmiş ve ilk olarak "Cohorikoi kai monachoi sten othomanike Chalkidike kata tous 15 o kai 16a ai.” (PhD diss., Thessaloniki, 2000) başlıkl doktora tezinde kullanmıştır.

57 Laiou, "Diverging Realities," s. 14.

58 Kolovos, "Christian Vakıfs," s. 116.

59 S. Laiou, bu durumu Midilli ve Teselya'dan iki manastır örneği ile açıklamaktadır. Bkz. Laiou, "Diverging Realities," 16-17; Örneğin, manastırlara yapılan bağışlarla ilgili olarak Xeropotamou Athonite Manastırı arşivinde Rumca tutulmuş 31 vakfiye bulunmaktadır. 
bu ikili hukuk durumunu "hybrid" (melez) sıfatı ile kavramlaştırmaktadır. ${ }^{60}$ Diğer taraftan, 19. yüzyılda gayrimüslim otoritelere kendi vakıflarını onaylama yetkisi verilmiş olmasına rağmen, Şam'da Rum-Ortodoks Patrikhanesi Arşivi'nde tespit edilen 1870 tarihli bir belgenin kadı huzurunda düzenlenmiş olması da ayrıca dikkat çekicidir. ${ }^{61}$

\section{Aykırı Gayrimüslimler ve Vakıfları}

Osmanlı toplumunun yapısal en önemli özelliği etnik ve dinî bakımdan çeşitliliğe sahip olmasıydı. Toplumun sosyal ve ekonomik faaliyetleri içiçe olmakla birlikte ayrışmanın görüldüğü tek alan din ile ilgiliydi. Bu da tabii bir durumdu. Toplumsal ilişkiler saygı esası üzerine oturmakta olup diğer inançlar, belli bir sınır içinde kalması şartıyla, hukukun koruması altındayd $1 .^{62}$ Diğer taraftan, öteki dinin lehine olacak doğrudan herhangi bir faaliyetten de kaçınılırdı. Örneğin, üç din mensubunun herhangi birinin, diğer dinin mabedi veya kurumuna doğrudan veya dolaylı olarak maddi destek sağlaması düşünülemezdi. Gayrimüslimlerin Müslüman mabetlerine hizmet edecek vakıf kurması her ne kadar İslâm açısından "kurbet" (meşru) sayılabilirse de, bu davranışşekli o dinlerin yorumuyla "masiyet" (gayrimeşru) kategorisinde yer alırdı. ${ }^{63}$ Diğer taraftan İslâm hukuku, gayrimüslimlerin kendi mabetleri için doğrudan vakıf kurmalarına da izin vermiyordu.

Bkz. Kolovos, "Christian Vakıfs," s. 116'dan naklen P. Gounarides, Archeio Ieras Mones Xeropotamou: epitomes metabyzantinon eggraphon [Archive of the Monastery of Xeropotamou: Summaries of Post-Byzantine Documents], Athonika Symmeitkta 3, 1993, s. 76, 78-90, 100102, 141, 146-153, 160-162, 177, 182, 190.

60 Kolovos, "Christian Vakifs," s. 116.

61 Meryem bt. Berkuda el-Dayr Atânî, Şam’da Nasara mahallesinde bulunan evini önce kendisine, sonrasında Saydnaya Manastırı'ndaki rahibelere vakfetmiştir. Bkz. Abdul-Karim Rafeq, "The Establishment of Christian Waqf in the Court Records of Ottoman Damascus: A Comparative Study," Les Fondations pieuses waqfs chez les chrétiens et les juifs: Du Moyen Âge à nos jours, ed. Sabine Mohasseb Saliba (Paris: Geuthner, 2016), s. 182-3'ten naklen Mahfûzât Batriarkiyyat Antâkiya wa-Sâir al-Mashriq lìl-Rûm al-Urthûdux, Damascus, Qism al-Tawthîq wa'l-Dirâsât at-Antâkiyya, (Damascus: University of Balamand, Matba'at Lizâr, 2001), vol. 1, 321. Rafeq, belgenin kopyasını da yayınlamıştır. Bkz. s. 194.

62 İslâm açısından gayrimüslim tebaanın hukuki durumu ve Osmanlıdaki uygulamalar hakkında genel bilgi için bkz. M. Macit Kenanoğlu, "İslam Hukuku ve Birarada Yaşam: -Osmanlı İstanbulu ve Gayrimüslimler-," Dinsel ve Kültürel Farklılıkların Birarada Yaşaması: İstanbul Tecrübesi (15-17 April 2010), ed. Mehmet Fatih Arslan, Muhammed Veysel Bilici (İstanbul: İÜ İlahiyat Fakültesi, 2010), s. 157-67.

63 Molla Hüsrev, Gurer ve Dürer, c. IV, s. 400. 
Buna karşılık, dinî farklılığa bir dereceye kadar riayet eden ve sonunda diğer din mensuplarının yararına olmak üzere bazı gayrimüslim vakıfları teşekkül etti. Memlük Kahire'sinde yaşayan Melkit bir Hıristiyan olan Süleyman b. Bişara b. Fahd'ın 1393 yılında kurmuş olduğu vakıf, tarih boyunca bu açıdan tespit edilmiş ilk örnektir. Evini vakfeden Süleyman vakfını önce kendisine, sonra bütün varislerine eşit şekilde, sonra St. Catherine Manastırı'nda yaşayan Melkit Hıristiyanları fukara ve hastalarına, sonra Kudüs'teki Melkit Hıristiyanlarına ve en sonunda da, nerede olursa olsun bütün Müslüman fukaraya şart etmişti. ${ }^{64}$ Süleyman, 1417 yılında yine aynı bölgede bir ev satın almış ve burayı da önceki vakfiyesinde olduğu gibi aynı şartlarla vakfetmişti. ${ }^{65}$ Bir Hıristiyan olan Süleyman b. Bişara, kurduğu vakıftan yararlanacaklar arasına Müslümanları da dahil eden tarihteki tek gayrimüslim değildi. Amnon Cohen'in Kudüs sicillerinde tespit ettiği bir Yahudi vakfı da bu açıdan oldukça ilginçtir. 1458'de Memlük Kudüs'ünde yaşayan Faslı Bannita bt. Bereket evini vakfetmiş ve vakfından yararlanacakları da sırasıyla kendisi, oğlu, onun çocukları şeklinde belirlemiştir. Neslinin kesilmesi durumunda sıradaki grup Yahudi fukarasıdır. Vakfın bundan sonraki nihai şartı ise Kubbetü’s-Sahrâ Camii olmuş ve Bannita'nın vakfı Osmanlı idaresinde de devam etmiştir. ${ }^{66}$

Osmanlı dönemine gelindiğinde de bu örneklere benzer nitelikte birtakım vakıflar kurulmuş ve arşiv kayıtları arasındaki istisnai yerlerini almışlardır. Örneğin beşi 16., altısı 17., ikisi 18. ve biri de 20. yüzyılda yaşamış on dört gayrimüslim, vakfiyelerine "Kubbetüs-Sahrâ Camii", "Medîne fukarâsı", "Haremeyn fukarâsı", "fukarâ-yı Müslimîn" gibi maddeler eklemek suretiyle vakıflarından nihai olarak Müslümanların veya Müslümanlara ait kurumların yararlanmasını istemişlerdir.

64 Donald S. Richards, “Documents from Sinai Concerning Mainly Cairene Property," JESHO 28 no: 3 (1985): 229-30; Bu tarz bir başka vakıf, Şam’da Kiryaki bt. Kassab Hûri isminde bir Rum-Ortodoks tarafından kurulmuştur. Kiryaki, Yahudi Mahallesi'nde bulunan evini bir aile vakfina dönüştürmüştür. Şart silsilesini önce kendisi ve ailesi, sonrasında Saydnaya Manastırı fukarası, nihai olarak ise, bütün din mensuplarını da kapsayacak şekilde "Şam fukarasının tamamı" olarak belirlemiştir. Bkz. Dımaşk ŞS, 134, 70 (14 Ramazan 1164/6 Ağustos 1751). Bu belgeye şu yayın vasıtasıyla ulaştım: Rafeq, "The Establishment of Christian Waqf," s. 174.

651446 yılına gelindiğinde, vakfın gelirleri tamirat giderlerini karşılayacak yeterlikte olmayınca, evlerden birincisi, manastır piskoposu ve yardımcısı tarafından el-Saifi Arghun b. Abdullah al-Alâi el-Şerifi isimli kişiye satılmıştır. Richards, "Documents from Sinai," s. 231-2.

66 Amnon Cohen, Jewish Life under Islam: Jerusalem in the Sixteenth Century, (Cambridge: Harvard University Press, 1984), s. 211. Cohen'in kaynak olarak gösterdiği Kudüs ŞS, 27, 292'de Bannita'nın vakfı ile ilgili kayda tesadüf olunamamıştır. Sanırım Cohen'in dipnotunda bir yazım yanlışı vardır. 
Yüzeysel bakıldığında gayrimüslim tebaanın dinî teamülleri ile toplumun genel temayülüne aykırı bir yerde duran bu on dört vakıf, tarih boyunca var olmuş bulunan diğer gayrimüslim vakıflarından da ayrılmaktadır. Zira, Müslümanları ve özellikle onlar için kutsal olan Haremeyn' ${ }^{67}$ gözeten şartlar, büyük çoğunlukla Müslüman vakıflarında görülen bir özellikti. ${ }^{68}$ Buna karşılık, aşağıdaki tabloda derlenen bu on dört aykırı vakıf kurucusunun hangi amaçla böyle bir tercihte bulundukları meçhuldür. ${ }^{69}$

67 Haremeyn Vakıfları, diğer bütün vakıflar içinde özel bir yere sahipti. Konu hakkında bk. Husam 'Abd al-Mu'ti, "Piety and Profit: The Haramayn Endowments in Egypt (1517-1814)," Held in Trust: Waqf in the Islamic World, ed. Pascale Ghazaleh (Cairo - New York: The American University in Cairo Press, 2011), s. 41-72; Lev, Charity, s. 76-81; Mustafa Güler, Osmanlı Devletinde Haremeyn Vakıfları (XVI. - XVII. Yüzyıllar) (İstanbul: TATAV, 2002); 'Abd al-Mu'ti, "Piety and Profit," s. 55; Haremeyn Vakıfları'nın denetimi amacıyla 16. yüzyılın sonlarında kurulan Evkaf-ı Haremeyn-i Şerîfeyn Müfettişliği için bkz. Kenan Yıldız, "Osmanlıda Vakıf Teftişleri ve Vakıf İdaresinin Merkezileşmesi," (Arapça olarak "Al Rajihi Waqf, Riyad” tarafindan yayına hazırlanıyor).

68 Ş. Tufan Buzpınar - Mustafa S. Küçükaşçı, "Haremeyn,” Türkiye Diyanet Vakfı İlâm Ansiklopedisi, 1997, XVI, s. 153-4. İlhak sırası gelen vakıflar gerekli hukuki işlemlerin ardından Haremeyn Vakıfları'nın mülkleri arasına dahil edilir ve her türlü tasarruf hakkı da Haremeyn Vakıfları'na geçmiş olurdu. Bu işlemlere dair bazı örnekler için bkz. Evkaf-1 Hümayun Müfettişliği ŞS (EHM ŞS), no: 1, vr. 23a/1, 24b/1, 30b/1-2; no: 48, vr. 104/1, 123/3, 124/1, $127 / 5,128 / 1-2,129 / 1,145 / 4,148 / 3,149 / 3$; no: 49 , vr. $2 / 2,14 / 2,15 / 2,16 / 2,26 / 2,27 / 2,28 / 2$, 35/1, 45/1, 50/2, 51/1; no: 54, 60b/3, 72a/1, 72b/2, 53b/1-2, 54a/1.

69 Tabii, böyle bir bilgiye ulaşmak belki de hiçbir zaman mümkün olmayacaktır. Amy Singer, kişilerin vakıf kurmaktaki asıl niyetlerinin tespit edilmesinin güçlüğüne ilişkin şöyle bir yorum getirmektedir: "Bir tarihçi, münferit kişiliklere ışık tutabilecek önemli otobiyografik kayıtların -günlükler, mektuplar, hatırat gibi- yokluğu karşısında, hayır işleyen herhangi bir kişinin samimi iyi niyeti hakkında hüküm vermekte zorlanacaktır. Modern öncesi İslam toplumlarının çoğunda böyle bir kanıt mevcut değildir." Singer, İyilik Yap Denize At, s. 142. Bu durumda, vakfiyelerinde Müslümanlar lehine şart tayin eden gayrimüslimlerin asıl niyetlerinin tespiti ise, daha çetrefil bir mesele olmaktadır. 
KENAN YILDIZ

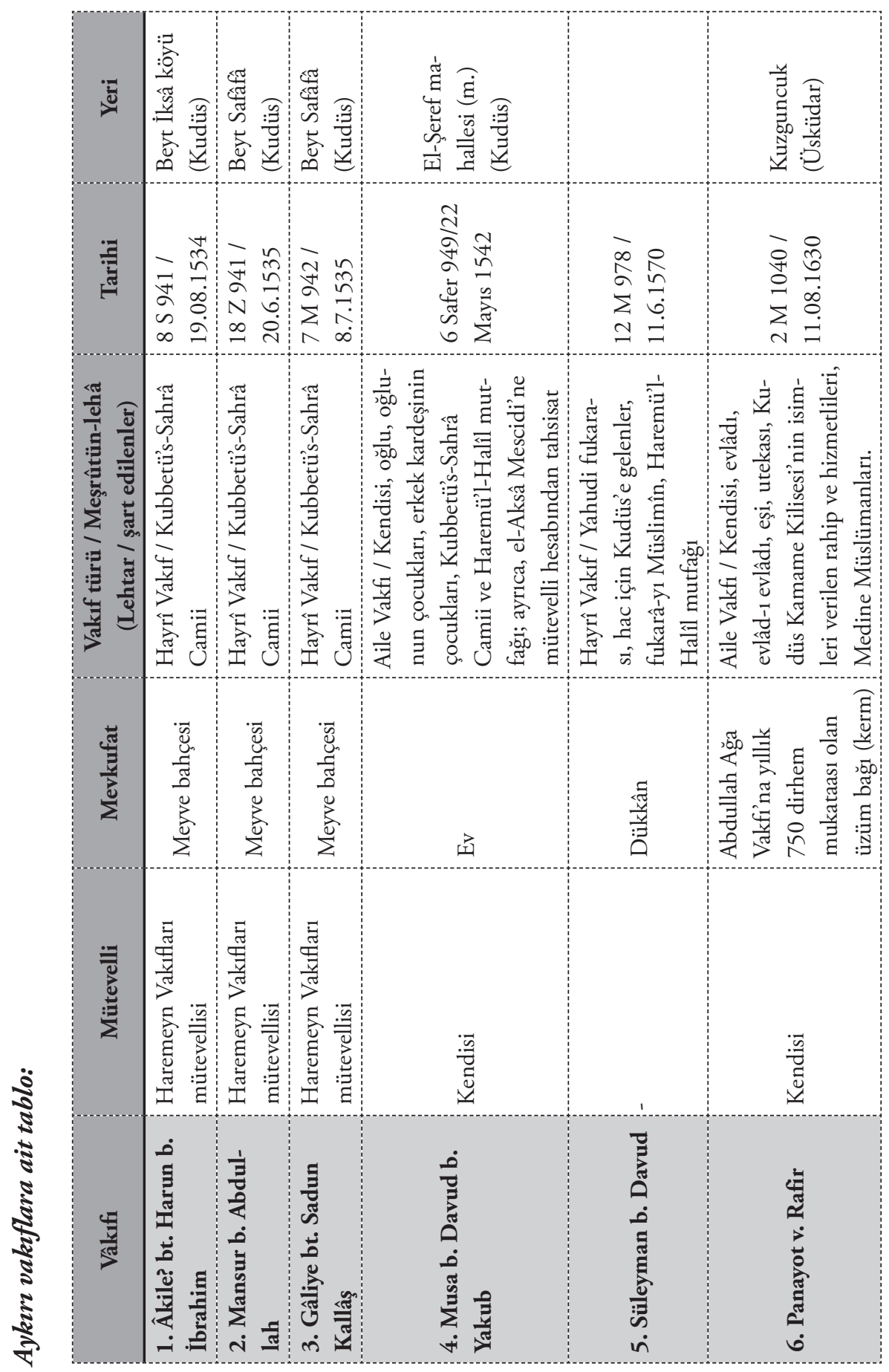


AYKIRI VAKIFLAR

\begin{tabular}{|c|c|c|c|c|c|c|c|c|}
\hline 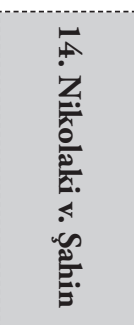 & 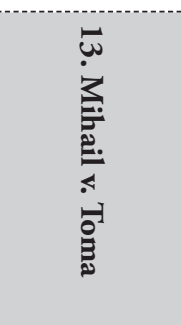 & 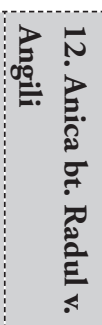 & 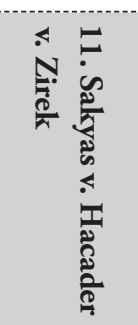 & 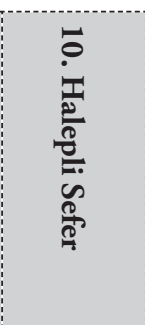 & 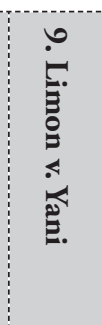 & 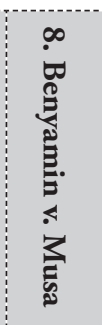 & 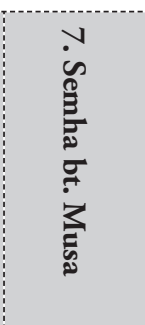 & 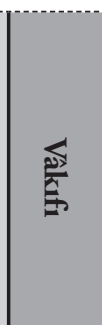 \\
\hline 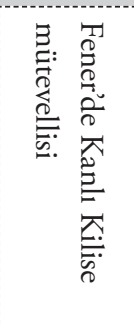 & & 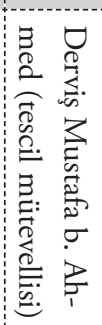 & 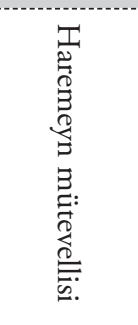 & & $\begin{array}{l}\text { त्र } \\
\stackrel{0}{0} \\
\underline{0}:\end{array}$ & 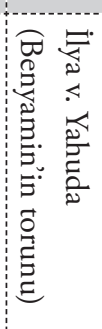 & 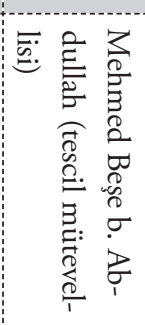 & 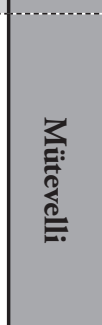 \\
\hline 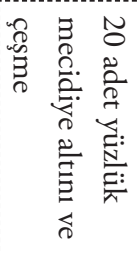 & T4 & T4 & प्य & T্য & 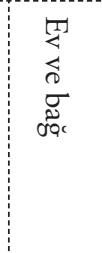 & T更 & प্ব4 & $\frac{a}{\hat{E}}$ \\
\hline 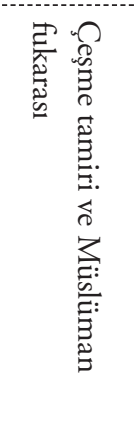 & 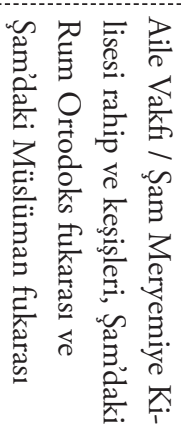 & 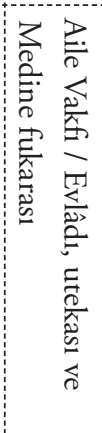 & 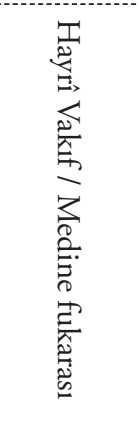 & 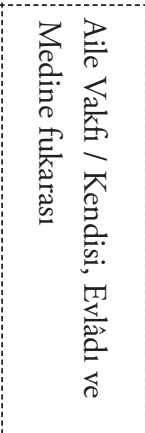 & 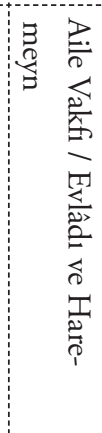 & 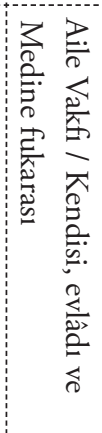 & 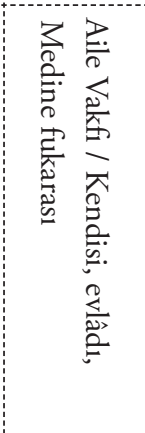 & 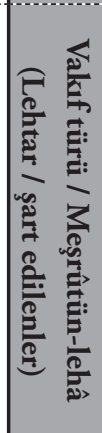 \\
\hline 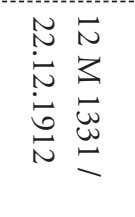 & 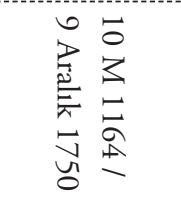 & 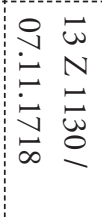 & 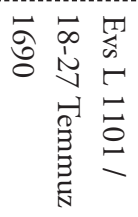 & $\begin{array}{l}\text { 㐫 } \\
\text { 离 } \\
\text { 心 }\end{array}$ & $\begin{array}{ll}N & 0 \\
0 & 0 \\
0 & N \\
0 & 0 \\
0 & 0 \\
\infty & 1\end{array}$ & $\begin{array}{ll}N & \infty \\
0 & 0 \\
0 & 0 \\
\vdots & 0 \\
心 & 0 \\
\omega\end{array}$ & 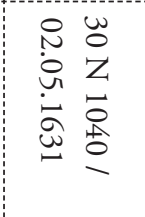 & $\underline{E}$ \\
\hline 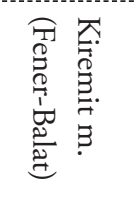 & $\mathscr{E}$ & 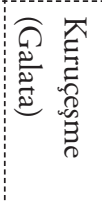 & 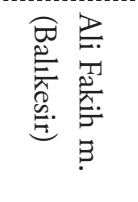 & 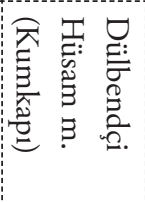 & 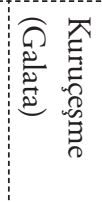 & 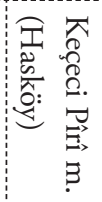 & 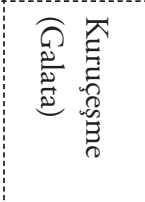 & \\
\hline
\end{tabular}




\section{1. Âkile? bt. Harun b. İbrahim Vakfi: $:^{70}$}

Şemile b. Yakub’un hanımı olan Âkile?, Beyt İksâ köyünde babasından miras kalan üzüm, elma ve incir ağaçlarının bulunduğu bir meyve bahçesini doğrudan Kubbetü's-Sahrâ Camii'ne vakfetmiş, vakfının tevliyetini de Haremeyn Vakıfları mütevellisine bırakmıstır.

\section{Mansur b. Abdullab Vakfi: ${ }^{71}$}

Şam'dan gelerek Kudüs'e yerleşen Mansur b. Abdullah, Beyt Safâfâda üzüm, elma ve incir ağaçlarının bulunduğu bir meyve bahçesinde sahibi olduğu dörtte birlik hissesini doğrudan Kubbetü’s-Sahrâ Camii'ne vakfetmiştir.

\section{Gâliye bt. Sadun Kallâş Vakfi: ${ }^{72}$}

Âkile ve Mansur gibi Gâliye bt. Sadun Kallâş isimli bir başka Yahudi de, Beyt Safâfâda bir Müslüman ile yarı yarıya ortak olduğu meyve bahçesini doğrudan Kubbetü’s-Sahrâ Camii için vakfetmiştir.

\section{Musa b. Davud b. Yakub Vakfi: ${ }^{73}$}

Kudüs sakinlerinden olan Musa b. Davud b. Yakub, Şeref mahallesinde satın aldığı evini vakfetmiştir.

70 Kudüs ŞS, 4, 277, hüküm no: 2057 (8 S 941/19 Ağustos 1534). Bu belgeye Amnon Cohen’in yayınları vasıtasıyla ulaştım: Amnon Cohen, Jewish Life under Islam: Jerusalem in the Sixteenth Century, (Cambridge: Harvard University Press, 1984), s. 210; Belge özeti için bkz. Amnon Cohen, A World Within: Jewish Life as Reflected in Muslim Court Documents from the Sijill of Jerusalem (XVIth Century), Part One (Texts), (Phliladelphia: University of Pennsylvania Center for Judaic Studies, 1994), s. 30. Belgenin kopyası için bkz. Amnon Cohen, $A$ World Within: Jewish Life as Reflected in Muslim Court Documents from the Sijill of Jerusalem (XVIth Century), Part Two (Facsimiles), (Phliladelphia: University of Pennsylvania Center for Judaic Studies, 1994), s. 18. Bkz. Ek-1.

71 Kudüs ŞS, 5, 82, hk. 360 (18 Z 941/20 Haziran 1535); Bu belgeye A. Cohen'in yayınları vasıtasıyla ulaştım: Cohen, Jewish Life under Islam, s. 210; Belge özeti için bkz. Cohen, $A$ World Within, Part One, s. 32. Belgenin kopyası için bkz. Cohen, A World Within, Part Two, s. 23. Bkz. Ek-2.

72 Kudüs ŞS, 5, 98, hk. 429 (7 M 942/8 Temmuz 1535). Bu belgeye A. Cohen'in yayınları vasıtasıyla ulaştım: Cohen, Jewish Life under Islam, s. 210; Belge özeti için bkz. Cohen, $A$ World Within, Part One, s. 33. Belgenin kopyası için bkz. Cohen, A World Within, Part Two, s. 24 . Bkz. Ek-3.

73 Kudüs ŞS, 14, 461, hk. 1564 (6 S 949/22 Mayıs 1542). Bu belgeye A. Cohen’in yayınları vasıtasıyla ulaştım: Cohen, Jewish Life under Islam, s. 211-2; Belge özeti için bkz. Cohen, A World Within, Part One, s. 54. Belgenin kopyası için bkz. Cohen, A World Within, Part Two, s. 73. Bkz. Ek-4. 
Şart silsilesi: Hayatta olduğu müddetçe kendisi, sonra oğulları ve onların çocukları, erkek kardeşinin çocukları. Bu silsilenin kesilmesi halinde vakıf geliri iki kurum arasında eşit olarak bölüştürülecektir. Bu kurumlar Kubbetü’s-Sahrâ Camii ve Haremü'l-Halîl mutfağıdır. ${ }^{74}$

Mütevelli: Kendisi, vefatından sonra da oğulları.

Musa’nın belirlediği ve ilginç olan bir şartı da, göreve her gelen mütevelli gelirinin bir karşılığı olarak Kubbetü’s-Sahrâ Vakfı ve el-Aksâ Mescidi Vakfi'na 50 dirhem ödeme yapacaktır.

\section{Süleyman b. Davud Vakfi: ${ }^{75}$}

Vakfından nihai olarak Müslümanların yararlanması şartını koyan bir diğer Yahudi de Süleyman b. Davud b. İshak'dır. Vakfın şartlarının belirtildiği belge Arapça’dır. Belgeye göre Süleyman, eskiden Kudüs'te oturmakta olup aslen Misırlı bir müstaribedir. Süleyman'ın bu dükkânları hukuksuz bir şekilde üzerine aldığı bir dava konusu olarak mahkemeye taşınmışsa da, onun vekili olan Ali İbrahim b. Hilal ve Şemile b. Yusuf, Süleyman'ın bu dükkânları Kudüs beytülmal emininin vekilinden meşru yollarla satın aldığı ve şartlarını da açıklayarak vakfettiğini söylemişlerdir.

Şart silsilesi: Kudüs'te yaşayan Yahudi fukara, Kudüs'e hacca gelen Yahudi fukarasi, sonrasında Müslüman fakir ve miskinlerine (fukarâ ve'l-mesâkînül-Müslimîn). Süleyman'ın nihai şartı ise Haremü'l-Halîl mutfağı olmuştur.

74 "Peygamber kabirleri sebebiyle İslâm âleminin her tarafından yıl boyunca gelen ve özellikle şehrin hac yolları üzerinde bulunmasından dolayı hac mevsiminde sayıları daha da artan ziyaretçiler Tanrı misafiri sayıldığından Haremü'l-Halîl'de ağırlanırlardı. Burada kendilerine "Halîl İbrâhim sofrası"nda, "men” denilen 1/2 kilogramlık bir ekmekle zeytin ve çorba gibi basit bir katıktan oluşan ve "es-simâtü'l-Halîlî, simât-1 şerîf, el-adesü’l-Halîl̂̂” adlarıyla anılan bir yemek ikram edilirdi. İslâm'dan sonra gelişen ve Hz. İbrâhim’in misafirperverliğini, cömertliğini sürdürmeyi amaçlayan bu âdet çok benimsenmiş ve bütün dönemlerde yaşatılmasına çalışılarak masraflarının karşılanması için özel vakıflar kurulmuştur.” Bkz. Abdüsselâm Uluçam, "Halîl: Haremü'l-Halîl," Türkiye Diyanet Vakfı İslâm Ansiklopedisi, 1997, XV, s. 308; Ayrica bkz. Amy Singer, Osmanlida Hayırseverlik: Kudüste Bir Haseki Sultan Imareti, çev. Dilek Şendil (İstanbul: Tarih Vakfı Yurt Yayınları, 2002), s. 172-3.

75 Kudüs ŞS, 53 , 339 (12 M 978/11 Haziran 1570). Bu belgeye A. Cohen’in yayınları vasıtasıyla ulaştım: Cohen, Jewish Life under Islam, s. 212; Belge özeti için bkz. Cohen, A World Within, Part One, s. 144. Belgenin kopyası için bkz. Cohen, $A$ World Within, Part Two, s. 261. Bkz. Ek-5. 


\section{Panayot v. Rafir Vakfi: ${ }^{76}$}

Vakfiye Arapça'dır. Aslen Rum olan Panayot, Abdullah Ağa Vakfi'na ait olan ve yıllık 750 dirhem mukataa ile tasarrufunda bulunan üzüm bağını (kerm) vakfetmiştir. ${ }^{77}$ Kuzguncuk'ta bulunan bağ, Abdi Çelebi b. Mehmed es-Sahhaf, Hatice Hatun mülkleri ve yol ile çevrilidir. Vakfiyeye göre bağ kiraya verilecek ve geliri ilgili yerlere sırası ile ulaştırılacaktır. Panayot'un vakfı, bağın kiraya verilmesi ve yıllık gelirinin hak sahiplerine eşit şekilde pay edilmesini öngörmekteydi. Müslümanlara şart edilmiş olması dışında vakfın birkaç önemli özelliği daha dikkati çekmektedir. Birincisi, Panayot'un vakfettiği bağ, Abdullah Ağa Vakfi'na ait yıllık 750 dirhem mukataalı arsa üzerinde bulunmaktayd $1{ }^{78}$ Bir vakıf arsa üzerinde, başka bir vakfin kurulup kurulamayacağı konusunda fukahanın görüşlerine de vakfiyede bir tartışma halinde yer verilmiştir.

Şart silsilesi: Önce nefsi, sonra nesli, sonra rahipler ve nihai olarak Haremeyn şeklinde üç aşamalı olarak belirlenmiştir. Buna göre Panayot vakfını ilk olarak kendisi, nesli, eşi ve utekâsına, sonrasında Kudüs'teki Kamame (Kıyamet) Kilisesi ${ }^{79}$ rahip ve diğer görevlilerine ${ }^{80}$ şart etmiştir.

76 Üsküdar Şeriyye Sicili, 163, 36b/1 (2 M 1040 / 11 Ağustos 1630). Bkz. Ek-6.

$77 \mathrm{Bu}$ kiralama usulüne göre, vakıf arsa üzerinde kiracı tarafından yapılan bina ve dikilen ağaçlar kendisinin özel mülkü olmaktaydı. Konunun ayrıntıları için bkz. Kenan Yıldız, 1660 İstanbul Yangın ve Etkileri: Vakıflar, Toplum ve Ekonomi (Ankara: TTK, 2017), s. 12330; Ayrıca bkz. Nazif Öztürk, "Mukataalı Vakıf," Türkiye Diyanet Vakfı İslâm Ansiklopedisi, 2006, XXXI, s. 132; Kuzey Afrika'da özellikle Mısır'da, arsaların uzun süreli olarak kiralanması uygulamasına XII. yüzyıldan itibaren "mukataalı vakıf" yerine "hikr" tabiri kullanılmıştır. Bkz. Mehmet İpşirli, "Hikr," Türkiye Diyanet Vakfı İslâm Ansiklopedisi, 1998, XVII, s. 525 .

78 Mukataalı yerlerde mutasarrıf, mülkiyetindeki gayrimenkulü kendi adıyla bir vakfa da dönüştürebilmekteydi. Bir örnek olması bakımından, Şeyh Ebülvefa ve Ayasofya vakıflarının ortak tasarruf ettikleri Vefádaki çifte hamam ile ilgili bir tamir kaydı için bkz. EHM ŞS, 51, 205/1 (104a) (4 Ra 1071/7 Aralık 1660). Mukataalı yerlerle ilgili bilgi ve örnekler için bkz. Yıldız, 1660 Istanbul Yangını, s. 141-2.

79 Hıristiyanlar için çok özel bir yere sahip olan Kamame Kilisesi'ne hac için gelenlerden Memlükler döneminde vergi alınmaktaydı. Osmanlılar da bu uygulamayı sürdürmekle kalmayıp, "resm-i Kamâme” denilen bu gelirlerden Kudüs'teki birtakım dinî hizmetler için vakıf kurmuşlardır. Kanuni tarafından kurulan vakfın tarihçesi, gelirleri gibi konularda ayrıntılı bilgi için bkz. Oded Peri, Christianity under Islam in Jerusalem: The Question of the Holy Sites in Early Ottoman Times (Leiden: Brill, 2001), s. 161-200.

80 Rahip ve diğer görevlilerin isimleri ayrı ayrı zikredilmiştir: Rahip Sofani v. Yani, Papas Yani v. Nikola, Papa Niko Dimo v. Yorgi, Papa Griyoryos v. Fraiya, Papa Niko Dimo v. Kürfe, Papa 
"kad vakafe ve habse ... cemî u’l-kerm el-mağrûs ... evvelen li-nefsihi mâlem yekün karînen bi'l-helâki sümme li-evlâdihi sümme li-evlâdi evlâdihi sümme li-evlâdi lievlâdi evlâdehu neslen ba'de neslin ve ferán gıbbe aslin sümme li-zevceti sümme li-'utekầiyihi sümme li'z-zimmiyyîn el-med uvvîn Sofani v. Yani er-râhib ve Papas Yani v. Nikola ve Papa Niko Dimo v. Yorgi ve Papa Griyoryos v. Fraiya ve Papa Niko Dimo v. Kürfe ve Papa Mitrofani v. Yani ve Papa Danyel v. Kostantin ve Papa Krillos v. Kostantin ve Papa Bretosgrilos Griyoryos v. Yani küllühüm min huddâmi'lkenîse el-ma'rûfeti bi-Kamâme bi'l-Kuds eş-Şerîf el-Mübârek el-mahrûse bi-haysi yûceri'l-kerm el-merkûm bi'l-icâreti'ş-şer 'iyyeti'l-mu'tâde hasbemâ-ceret bihi'l-âde bi-yedi'l-mütevellî ale'l-kermi'l-merkûm ve yürselü mahsûlehu külli seneti ile'zzimmiyyîn el-mezkûrîn ve yüksemu beynehüm ale's-seviyye ..."

Haremeyn şartı: Panayot, vakfını nihai olarak Medine Müslümanlarına şart koşmuştu. Bu şarta göre, hak sahiplerinin tamamının vefatı sonrasında vakıf, Medine (Haremeyn) Vakıfları'na ilhak olunacak, bağ kiraya verilecek ve elde edilen gelir de Medine'de yaşayan fukarâ-yı Müslimîne ulaştırılacaktı.

“ve inni heleküvâ cemî‘an yühlaku bi-evkâfi'l-Medîneti'l-Münevvere bi-haysi yûceri'l-kerm el-merkûm bi'l-icâreti'ş-şer iyyeti'l-mu'tâde ve yürselü icâreti'lhâsılatihi minhü ile'l-fukarâi'l-Müslimîn es-sâkinîn fîhâ”

Vakıf mütevellisi, hayatta oldukça Panayot'un kendisi, vefatından sonra ise Mahmud Çelebi b. Mehmed olacaktı. Diğer taraftan, şahitler arasında Kassam-ı Askerî İbrahim Efendi, Kadı Hasan Efendi, Kadı Hüseyin Efendi, Kadı Osman Efendi ve Müderris Abdülkerim Efendi gibi ilmiye mensubu önemli kimselerin bulunması vakfiyeye ayrı bir hususiyet kazandırmaktaydı.

Vakfiyede dikkati çeken ikinci nokta, Kudüs'teki Kamame Kilisesi rahipleri ve görevlilerinin isimlerinin tek tek sayılmış olmasıdır. Gayrimüslim vakıflarında adet ve kanun olarak "kilise fukarâsi" ibaresi zikredilmekteyken, burada kilise mensubu kişilerin isimlerinin verilmiş olması ayrıca dikkati çekmektedir.

\section{Semba bt. Musa Vakfi ${ }^{81}$}

Vakfiye Arapça'dır. Aslen Yahudi olan Semha bt. Musa, Beşiktaş Kuruçeşme’de bulunan mülk menzilini hayatta olduğu müddetçe kendisine, sonrasında evlâdına, evlâd-1 evlâdına, nesli kesildikten sonra ise Medine fukarasına vakfetmiştir.

Mitrofani v. Yani, Papa Danyel v. Kostantin, Papa Krillos v. Kostantin ve Papa Bretosgrilos Griyoryos v. Yani.

81 EHM ŞS, 7, 65a-b (30 N 1040 / 02 Mayıs 1631). Bkz. Ek-7. 
"el-Yahûdiyyetü el-med'ûvvetü Semha bt. Musa es-sâkinetü bi-mahalleti Çelebioğlu min mahallâtı Kostantıniyye el-mahmiyyeti bi-inahâ kad-vakafet ve habeset mâ-hüve lehâ ve mülkehâ ve tahte tasarrufehâ ilâ hîni sudûri hâze'l-vakf minhâ ve zâlike'l-menzilü el-vâki' bi'l-mevzi' el-ma'rûf bi-Kuruçeşme min tevâbi'i kasabai Beşiktaş min müzâfâti Galata el-mahmiyye ... ve şaratet süknâh evvelen li-nefsihimâ mâ-dâmet hiye hîn sümme li-evlâdihâ ve evlâdi evlâdi evlâdihâ ile'linkırâz ve ba 'de'l-inkırâz yastağilü'l-menzil el-mezbûr men kâne mütevelliyyen alâ evkâfi'l-Haremeyn el-muhteremeyn ve yürselü galletü ilâ fukarẩi'l-Medînetü'lMünevvere"

İki katlı, şehnişinli, bahçesi ve mahzeni olan bu ev, İsak ve Salti v. Musa'ya ait ev ile komşudur. Tamire ihtiyaç olması halinde giderler, evde oturan kişi tarafindan karşılanacaktır. Vakfiyede, aile vakfının fikhi geçerliği de vurgulanmıştır.

“el-mahdûd bi-mülki İsak ve Salti veledey Musa mine'l-etrâfi's-selâseti bi't-tarîki'l'âmm min tarafi'l-hâvî alâ beyti ulvî máa gurfetü’l-mu'abbere bi-şehnişîn ve mahzen ve hadîka ve arzı hâliyye ve kenîf ve muhavvatatü bi-cümleti't-tevâbi ve'l-levâhık ve kâffeti'l-menâfi' ve'l-merâfik ... ve şaratet et-termîm lede'l-hâce li-külli men-yesâkin-fîhi”

Bir aile vakfı olarak kurulan Semha bt. Musa Vakfínın lüzûmu (geri döndürülemezliği) üzerine fikhî tartışma da vakfiyenin bir bölümünü teşkil etmektedir.

“in şarata el-vâkıfetü'l-mezbûre süknâ el-mevkûf li-nefsihi yubtile'l-vakf inde Muhammed -rahmetullâhi teâlâ- fe-acâbe el-mütevellî el-mezbûr bi-enne's-shhati lâ-yüfârık ani'l-lüzûm alâ mezhebi ba'zi'l-meşâyihi'l-kirâm ve inne şarti'l-vâkıf men'ati'l-vakfe li-nefsihi cẩiz indi Ebî Yusuf fetehâsamâ ve tenezeâ hattâ terâfa â ile'l-hâkimi'l-muvekki' a'lâhu el-mütevakki' rizâen mevlâhu felemmâ ra'a elhâkim el-hâsim el-müşârün-ileyh esbağallahu teâlâ ni'amehu aleyhi cânibi'l-vakf evlâ ve ahrâ hakeme bi-sıhhati ve lüzûmihi fî husûsihi ve umûmihi alâ kavli menyerâhu mine'l-e'immeti'l-müctehidîn -rıdvânullâhi teâlâ aleyhim ecma în- fe-sâra vakfen lâzimen müseccelen mü’ebbeden”.

\section{Benyamin v. Musa Vakfi}

Bir Karaim Yahudisi olan Benyamin v. Musa, "Kurd" ismi ile meşhurdur. Osmanlı topraklarında yaşayan Yahudi cemaatlerinin bu dönemdeki hakim unsuru sayılan "Edirne Yahudiler Cemaati”nden olan Benyamin, Hasköy Keçeci mahallesinde bulunan evlerini vakfetmiştir. Vakfiyesi, Evkaf-1 Hümayun Müfettişliği, 
Rumeli Kazaskerliği ve Havass-1 Refia (Eyüp) mahkemeleri defterlerinde üç nüsha olarak kayıtlıdır. ${ }^{82} 1655$ zira' (1252 m2) arsa üzerinde birbirine paralel yapılanmış ve iki katlı olan evlerin iki tarafında biri hususi, diğeri umumi yol, bir tarafında Yasef v. Yahuda mülkü ve diğer tarafında ise Karaimlere ait sinagog bulunmaktadır.

“... Havâss-1 Kostantıniyye tevâbi'inden kasaba-i Hasköy mahallâtından Keçeci mahallesi kurbunda sâkin Edirne cemâ‘atinden Kurd demekle meşhûr işbu bấisü̉l-kitâb Bünyamin v. Musa nâm yahûdi ... ikrar ve i'tirâf kılıp tasarrufumda olan emlâkimden mahalle-i mezbûrede vâki' bir tarafi Yasef v. Yahuda mülkü ile ve bir tarafı kenise ile ve bir tarafı tarîk-i hâss ile ve taraf-ı âharı tarîk-i âmm ile mahdûd olup bennâ zirấryla tûlen ve arzen bi-hisâb-1 şartrancî bin altı yüz elli beş zirâ‘ arsa üzerinde mebnî üç bâb beyt-i ulvîyi ve müteferrik iki bâb diğer ulvî odayı ve dehliz ve şehnişini ve bir hamam ve bir matbah ve firını ve iki kenifi ve tahtında bir bâb mahzen ve muhavvatayı muhtevî menzilimi ve menzil-i mezbûr muhâzîsinde diğer iki bâb beyt-i ulvî ve bỉr-i mầ ve hadîkayı müştemil emlâkimi tevâbi'i ile vakf ve habs edip"

Şart silsilesi: Benyamin'in şart silsilesinde ilk sırada kendisi bulunmaktadır. Sonrasında eşi Pandriye bt. Musa, sonrasında oğulları ve onların çocukları, onlardan sonra kızları Manaka ve Kasari ile onların çocuklarına şart etmiştir. Bu şartlarını sıraladıktan sonra tekraren "evlâd-ı zükûrumdan kimesne var iken evlâd-ı inâsım menzil-i mezbûra ta'arruz eylemeye" şeklinde, erkek çocukları hayattayken, kızlarının evden istifade etmemeleri şartını koymuştur.

"şöyle şart ve bu üslûb üzre rabt eyledim ki evvelâ menzil-i mezbûrda kendim sâkin olmup nice dilersem tasarruf eyliyim benim helâkimden sonra zevcem Pandriye bt. Musa nâm yahudiye sâkine ola ba'de helâkihâ evlâd-1 zükûrum batnen ba'de batnin sâkin olup tasarruf edeler ba'de'l-inkırâz evlâd-ı inâsımdan Manaka ve Kasari nâm yahudiyetân mutasarrıfetân olalar ba'de hâzihî evlâd-1 evlâd-ı evlâdı mutasarrıfe olalar evlâd-1 zükûrumdan kimesne var iken evlâd-1 inâsım menzil-i mezbûra tasarruf eylemeye ve şöyle şart eyledim ki ashâb-1 şurûtdan menzil-i mezbûru tasarrufdan müstağnî olurlar ise âhara îcâr olunmayıp hâlî dura"

Mütevelli ve nazır tayini: Benyamin, mütevelli olarak kızı Manaka’nın (Yahuda) oğlu İlya’yı, nazır olarak da damatları İlya v. Salamon ile Yahuda v. Yasef’i tayin

82 EHM ŞS, 7, 155a-b. Bkz. Ek-8; Havass-1 Refia ŞS, 45, 51b-52a; Rumeli Kazaskerliği ve Sadareti ŞS, 57, 20a-b (12 R 1043/12 Mart 1634). Kâtiplerden kaynaklanmış olan bazı imla farklılıkları olmakla birlikte vakfiye suretlerinin üçü de aynıdır. 
etmiştir. İlya’nın vefatı sonrasında onun yerine, şart silsilesi içinde yer alanlardan yaşça büyük olan geçecekti:

"İlya hâlik oldukda menzil-i merkûme meşrûtiyet üzre mutasarrıf olanların müsin olanına meşrûta ola”.

Tamirat ve istibdal: Tamirat gerektiğinde bunun tasarruf hakkına sahip olanlar tarafından karşılıksız olarak yerine getirilmesi şartlarını da birer madde olarak vakfiyesine ekletmiştir. Hatta, tamir masrafından kaçınan hak sahiplerinin tasarruf haklarının da iptal edilmesini istemiştir. Mutasarrıflar eğer tamirat veya yeni bir bina yaptırmak istediklerinde karşılıksız (teberru) olması şartı ile bunu mutlaka mütevelli ve kadıdan izin alarak gerçekleştirmeliydiler. Bir başka önemli şart da, "menzil-i mezbûr âhar menzil ile mübâdele olunmaya" cak yani, hiçbir şekilde istibdal (takas) yapılmayacaktır.

"menzil-i mezbûra meremmet lâzım geldikde mutasarrıf olanlar teberru' olmak üzre mallarından meremmet edeler ve ashâb-1 şurûtun ba'zısı menzil-i mezbûru meremmet edip ve ba'zı âharı meremmetden imtinâ‘ ederse meremmet edenler menzil-i mezbûra mutasarrıf olup imtinâ‘ edenler tasarrufdan men`olunalar”

Kiraya verme: Benyamin v. Musa’nın kiralama konusunda öngördüğü şartlar da ilginçtir: "Ashâb-ı şurûtdan menzil-i mezbûru tasarrufdan müstağnî olurlar ise âhara îcâr olunmayıp hâlî dura" cak yani, vakıfta şart silsilesi içinde yer alanlar bu evleri tasarruf etmek istemezler ise, evler kiraya verilmeyecek, boş bırakılacaktır. Nesil kesilip ev Haremeyn Vakıfları'na ilhak olundukdan sonra ise, "menzil-i merkûme icâre ile cemâ'at-i mezbûreden tâlib var iken âhara verilmeye"cek yani, kiralamaya talip olanlar arasında öncelik hakkı Edirneli Yahudiler Cemaati'ne ait olacaktır.

Haremeyn şartı: Benyamin, Haremeyn konusunda oldukça hassastır. Zira Benyamin, vakıftan yararlananlar hayattayken de Haremeyn'e bir pay verilmesini şart koşmuştur. Yani, neslin kesilmesi ve vakfının ilhakı beklenmeksizin her yıl mutlaka 20 akçenin Haremeyn'e gönderilmesini istemiştir: "menzil-i mezbûru tasarruf edenler beher sene Haremeyn-i Şerîfeyn mütevellîsine yirmi akçe vereler". Benyamin, henüz hayatta iken Haremeyn'e bir pay tahsis etmekle diğer vakıf kurucularından ayrılmaktadır. Şart silsilesindeki isimler ölene ve nesilleri de kesilene kadar bu şartlar çerçevesinde devam ettirilecek olan vakıf, nihai olarak da Haremeyn Vakfı'na bağlanacaktır. Bundan itibaren ev, Haremeyn mütevellisi tarafından kiraya verilebilecek, kira geliri "Haremeyn-i Muhteremeyn fukarâsına" ulaştırılmak üzere, her yıl gönderilen surreye dahil edilecektir: 
"bu cümle münkariz oldukdan sonra menzil-i merkûm Haremeyn-i Şerîfeyn mütevellîsi yediyle ecr-i misli ile âhara îcâr olunup hâsıl olan icâresi her sene Haremeyn-i Muhteremeyn fukarâsına irsâl olunan surreye idhâl oluna”

Vakfiyede, vakıftan yararlanacakların nesilleri kesilene kadar kiraya verilmemesi gibi kesin bir şart bulunmaktaysa da, evin Haremeyn Vakıfları'na ilhak olunmadan önce kiraya verilmeye başladığı anlaşılmaktadır. Bunu yansıtan bir keşif belgesinde vakıf yer için "menzil" yerine "yahudihane" ibaresi kullanıldığı da ayrıca dikkati çekmektedir. Benyamin v. Musa’nın mütevelli atadığı Yahuda v. Yasef' in hâlâ bu görevine devam ettiğini gösteren 1664 yılındaki söz konusu keşif kaydına bakılırsa, kiraya verme uygulamasının çok önceleri başladığı tespiti yapılabilir. Yahuda’nın ifadesine göre, yahudihanenin tamir edilmesi gerekmiş ve tamirat masrafları bu tarihe (1664) kadar birikmiş olan kira parası ile karşılanmış. Hatta tamirat harcamaları verildikten sonra bir miktar da para artmış ve bu artık para değerlendirilerek yahudihaneye ilaveten yeni iki oda ve üç matbah yaptırılmış. Bütün bu giderlerin toplamı da 62.269 akçeyi bulmuş. ${ }^{83}$ Buna mukabil, 1680 tarihli bir belgeden anlaşıldığına göre de Benyamin’in vakfettiği evlerden biri, Edirne Cemaati mensubu İlya v. Menahim isminde bir Yahudiye 1676 yilında kiraya verilmiştir. Diğer taraftan, bu tarihte vakıf mütevellisi olarak adı geçen kişinin Mehmed Çavuş isminde bir mühtedi olması ayrıca dikkati çeken bir durum olarak zikredilmelidir. ${ }^{84}$

\section{Limon v. Yani Vakfi}

Aslen Rum olan Limon v. Yani, Kuruçeşme sakinlerinden olup 'Bebek semtinden' anlamında "Bebekli Limon” olarak da bilinmektedir. Limon'un vakfettiği bir ev, iki bağı da Kuruçeşme'de bulunmaktadır. Sicillerde bu vakıf ile ilgili toplam dört kayıt tespit edilmiştir. Bunlardan biri vakfiye, ${ }^{85}$ biri Haremeyn'e ilhakı gerçekleşen menzilin, ${ }^{86}$ ikisi ise bağların ${ }^{87}$ sınırları ve durumlarını gösteren belgelerdir.

83 EHM ŞS, 54, 118b/2-119a (26 N 1074/22 Nisan 1664).

84 Fuat Recep ve dğr. (yay. haz.), İstanbul Kadı Sicilleri: Eyüb (Havass-ı Refìa) Mahkemesi 90 Numaralı Sicil (H. 1090 - 1091 / M. 1679 - 1680), proje yön. M. Âkif Aydın, ed. Coşkun Yılmaz (İstanbul: İSAM Yay., 2011), 38b/4, s. 258 (11 Z 1090/13 Ocak 1680). Mehmed Çavuş่un ihtida etmeden önceki ismi hakkında herhangi bir tespit yapılamamıştır. Bununla birlikte, vakfiye şartlarına bakılırsa vâkıf Benyamin v. Mosi'nin torunlarından biri olmalıdır 85 EHM ŞS, 7, 210b/3 (10 Za 1047/26 Mart 1638). Bkz. Ek-9a.

86 EHM ŞS, 48, 128/1 (64b), (18 M 1062/31 Aralık 1651). Bkz. Ek-9b.

87 EHM ŞS, 48, 127/5, 128/2 (64a-b), (23 M 1062/5 Ocak 1652). Bkz. Ek-9c-d. 
Mülkler: Ev: Sultan Bayezid Evkafı'ndan mukataalı arsa üzerinde 190 zira‘ (144 m2) olup iki katlıdır. ${ }^{88}$ Deniz kenarında bulunan ev, Murad Usta b. Abdullah ve Haydar b. Abdullah mülkleri ile de komşudur. ${ }^{89}$ Evin Haremeyn Vakıfları'na ilhak olunduğu Aralık 1651'de (vakfiye 1638'de düzenlenmiştir) ise evin sınırları verilirken Murad Usta ve Haydar'a ait yerler sayılmamıştır. Bunlar yerine deniz, yol ve Hristodoli zimmî mülküne komşu olduğu belirtilmiştir. ${ }^{90}$ Geçen zaman zarfında vakıf evin çevresindeki yerlerin el değiştirmiş olması muhtemeldir.

Bă̆: Yorgi v. Kostantin'in tarlası ve Murad Usta’nın bağ ile komşu olup 3 dönümdür. ${ }^{91}$

$B a \breve{g}$ : Papa Kolika, Kovako, Hekimoğlu olarak bilinen bir Yahudi ve Kostantin’e ait tarlalar ile çevrili olup 9 dönümdür. ${ }^{92}$

"Mahmiye-i Galata'ya tâbi' Kuruçeşme nâm karye sâkinlerinden Limon v. Yani nâm zimmî meclis-i şer'-i şerîf-i Nebevîde vakf-1 câi'z-zikri tescîl için mütevellî nasb ve ta'yîn eylediği Murat v. Mihrişâh nâm Ermeni mahzarında ikrâr ve takrîr-i kelâm edip karye-i mezbûrede vâki‘ arsasının merhûm ve mağfûrun-leh Sultan Bayezid Hân -tâbe serâhu- Evkâfına senede altmış iki akça mukâta'ası olup bir tarafı Murad Usta mülkü ve bir tarafı Haydar b. Abdullah mülkü ve bir tarafı sâhil-i bahr ve bir tarafı tarîk-i âm ile mahdûd iki bâb fevkânî beyti ve altında mahzeni ve kenîfi müştemil münâza'a ve muhâsamadan ârî olan mülk menzili ve yine karye-i mezbûrede vâki` bir tarafı Murad Usta b. Abdullah tarlası ve bir tarafı Yorgi v. Kostantin bağı ve iki tarafı tarîk-i âm ile mahdûd bağımı ve yine karye-i mezbûre sınırı dâhilinde vâki` bir tarafı Papa Kolika v. ( ) mülkü ve bir tarafı Kovako v. () ve bir tarafı Hekimoğlu demekle ma' rûf yahudi tarlası ve bir tarafı Kostantin v. ( ) mülkü ile mahdûd bağımı cümle tevâbi' ve levâhıkı ile vakf-1 müeyyed ve habs-i muhalled edip ..."

Mütevelli: Tevliyet başta Limon v. Yani'ye (kendisine), sonrasında Aleksandra ile onun neslinden yaşça büyük olana aittir: "vakf-ı mezbûrun tevliyeti bana meşrûta olup helâkimden sonra mezbûr Aleksandra'ya meşrûta ola ve ba'dehû aslah-ı evlâdından vakf-ı mezkûra meşrûtiyet üzre mutasarrifolanlarn müsinn olanlarına meşrûta ola". ${ }^{93}$

88 EHM ŞS, 48, 128/1 (64b), (18 M 1062/31 Aralık 1651).

89 EHM ŞS, 7, 210b/3 (10 Za 1047/26 Mart 1638).

90 EHM ŞS, 48, 128/1 (64b), (18 M 1062/31 Aralık 1651).

91 EHM ŞS, 48, 127/5, (64a), (23 M 1062/5 Ocak 1652).

92 EHM ŞS, 48, 128/2 (64b), (23 M 1062/5 Ocak 1652).

93 EHM ŞS, 7, 210b/3 (10 Za 1047/26 Mart 1638). 
Şart silsilesi: Limon v. Yani'nin şart silsilesinin başında kendisi bulunmakta olup hayatta olduğu müddetçe vakıftan istifade edecektir. Eş veya çocuğu bulunmayan Limon, Aleksandra v. Foça ile birlikte aynı evde oturmaktadır. Kendisinden sonra vakfını bu kişiye ve onun nesline, nesilleri kesildikten sonra ise nihai olarak Haremeyn'e şart etmiştir.

“.. şart eyledim ki, evvelâ zikr olunan menzil ve bağların süknâsı ve tasarrufu hayâtda olduğumca yedimde olup nice dilersem tasarrufuma âhardan ... kimesne mâni' olmaya ve helâkimden sonra hâlen benimle sâkin Aleksandra'ya meşrût ola ve ba'de helâkihî evlâdı evlâd-ı evlâd-ı evlâdı yedinde ola ve vakf-1 mezkûr tevliyeti bana meşrût olup helâkimden sonra mezbûr Aleksandra'ya meşrût ola ve ba'dehû aslah-1 evlâdından vakf-1 mezkûra meşrûtiyet üzre mutasarrıf olanların müsinn evlâdlarına meşrût ola ..."

Tamirat: Tamirat gerektiğinde bunu tasarruf hakkına sahip olanlar karşılıksız olarak yerine getireceklerdir. Tamir masrafından kaçınanların vakıftaki tasarruf hakları iptal edilecektir. Mutasarrıflar tamirat veya yeni bir bina yaptırmak istediklerinde, bunu karşılıksız (teberru) olması şartı ile mutlaka mütevelli ve kadıdan izin alarak gerçekleştirmeliydiler. Belgedeki ifadeler şu şekildedir:

"menzil ve bağlar mürûr-1 eyyâm ile harâba müşrif olup támîre muhtâc oldukda meşrûtün-aleyhimden sâkin ve mutasarrıf olanlardan her biri nevbetlerinde ebniye-i cedîde ve meremmet murâd eylediklerinde izn-i şer'î ve ma'rifet-i mütevellî ile binâ edip sarf eyledikleri akçe vakfa teberru' ola ve ashâb-1 meşrûtdan ba'zısı meremmet edip ve ba'zıları imtinâ' ederse meremmet edenler sâkin ve mutasarrıf olup imtinâ edenler tasarrufdan men' olunalar”.

Haremeyn şartı: Şart silsilesindeki isimler ölene ve nesilleri de kesilene kadar bu şartlar çerçevesinde devam ettirilecek olan vakıf, nihai olarak Haremeyn Vakfi'na bağlanacaktır. Bundan itibaren ev ve bağlar, Haremeyn mütevellisi tarafından kiraya verilebilecek, kira geliri de her yıl gönderilen surreye dahil edilerek Haremeyn'e iletilecektir:

“... cümle münkariz oldukdan sonra mârrü’z-zikr menzil ve bağlar Haremeyn-i Şerîfeyn mütevellîsi yediyle ecr-i misliyle âhara îcâr olunup hâsıl olan icâresi her sene Haremeyn-i Muhteremeyn fukarâsına irsâl olunan surreye idhâl oluna ...”.

Limon veya Aleksandre'den hangisinin önce ölmüş olduğunu tespit edemiyorsak da, 1651 sonlarında vakfın şart edildiği herhangi bir kimsenin bulunmadığ 
kesindir. Zira, Limon’un 1638 yılında kurmuş olduğu vakfa ait mülkler, değinilen belgelerde görüldüğü üzere 1651 yılı sonlarında “meşrûtün-leh olanlar bi'l-külliye münkariz olup", "ber-mûceb-i şart-ı vâkıf" yani, vakıftan yararlananlardan hayatta kimse kalmayınca Haremeyn Vakıfları'na ilhak olunmuştur. ${ }^{94}$

\section{Halepli Sefer Vakfi}

Sefer, aslen Halepli bir Ermenidir. ${ }^{95}$ Vakfiyesine sicil kayıtlarında tesadüf olunamamıştır. Sefer'in kurmuş olduğu aile vakfı hakkındaki bilgilere, Haremeyn Vakıflarına ilhakın gerçekleştiğini gösteren iki belge üzerinden ulaşılmıştır. Bu belgelerdeki ifadelere bakılırsa, Sefer' in vakfiye yerine bir vasiyetname düzenlediği anlaşılmaktadır. Zira Halepli Sefer, malının üçte birini vasiyet ederek vakfetmiş bulunduğu (terekesinin sülüsünden vakf olup) söz konusu belgelerdeki ifadelerde açık şekilde görülmektedir.

Sefer, Kumkapı Dülbendçi Hüsam mahallesinde bulunan iki katlı mülk evini aile vakfına dönüştürmüştür. 139 zira’lık (105 m2) bir alanı kaplayan ev, iki taraftan Makasçı Avadik'in evi, bir taraftan Dülger Bali evi ve diğer taraftan da yol ile çevrilidir. ${ }^{96}$

"mahmiye-i İstanbul'da Dülbendçi Hüsam mahallesinde vâki' birtarafdan tarîk-i âmm ve iki tarafdan Makasçı Avadik mülkü ve bir tarafdan Dülger Yani mülkü ile mahdûd iki bâb fevkânî ve bir bâb tâhtânî oda ve kenîf ve müşterek su kuyusunu müştemil menzili mâliki olan Halepli Sefer nâm zimmî vakf ... edip"

Şart silsilesi ve Haremeyn şartı: Sefer, kurduğu aile vakfını önce kendisi, sonra çocukları, nesli kesildikten sonra da Medine fukarasına şart etmiştir.

"süknâsını evvelâ kendüye sonra ile'l-inkırâz evlâdına ve evlâd-ı evlâdına ba'de'linkırâz Medîne-i Münevvere fukarâsına şart ve ta'yîn edip"

Söz konusu ev, Sefer’in vefatı sonrasında, varisler tarafından mülk yermiş gibi Avraham v. Aleksendi'ye satılmıştır. Haremeyn mütevellisinin iddiasına göre ev, "hâlik-i mezbûrun terekesinin sülüsünden vakf olup gayrı meşrûtün-leh

94 EHM ŞS, 48, 127/5, 128/1-2 (64a-b), (18-23 M 1062/31 Aralık 1651-5 Ocak 1652).

95 Evin, Haremeyn Vakıfları'na ilhak edilme sürecinde kaydedilen iki hüccetten birinde vâkıf

"Halepli Sefer", diğerinde de "Sefer zimmî" şeklinde zikredilmekte ve baba adı verilmemektedir.

96 EHM ŞS, 50, 27/1 (Evh Za 1065 / Eylül 1655). Bkz. Ek-10a. 
olmamağla Medine-i Münevvere Vakfı tarafina intikâl etmiş"ti. Konunun soruşturulması sonucunda, Avraham'ın buranın vakıf yer olduğunu bilmediği ve bunu da kabul etmediğinin anlaşılması üzerine Haremeyn mütevellisinden yerin vakıf olduğunu ispatlaması istenmiştir. Şahit olarak mahkemeye gelen Halepli el-Hac Yusuf b. Muhammed, Şamlı el-Hac Zeyn b. Bedreddin, Sefer'in vakfını vefatından üç yıl önce kurduğunu ve nihai olarak Medine fukarasına şart ettiğini ifade etmişlerdir.

“... fi'l-hakîka hâlik-i mezbûr Sefer sıhhat ve neffâz-1 tasarrufâtında helâkinden üç sene mukaddem menzil-i mezbûru yedinde mülkü olduğu halde vakf edip süknâsını evvelâ kendüme ve ba'de'l-inkırâz gallesini Medîne-i Münevvere fukarâsına şart eyledim deyû huzûrumuzda kirâren ikrâr ve bizi işhâd edip musırrân hâlik olmuşdur..."

Hatta bu da yeterli görülmemiş, mahkemeye gelecek durumda bulunmayan diğer şahit Bedreddin'in tanıklığına başvurulmuş, o da vakfın kuruluşunu ve şartlarını aynı şekilde sıraladıktan sonra bu ifadelerinin mahkemeye iletilmesini istemiştir. Mahkeme, şahitlerin tanıklıklarını kabul ederek yerin vakıf olduğuna hükmetmiş, fakat terekenin üçte birinin vakfedildiği hususunun araştırılması kararını vermiştir.

\footnotetext{
"husûs-1 mezbûrun aslına şâhid olup marîz olmağla huzûru meclis-i şser'a müte'azzir olup mârrü̈z-zikr Gedikpaşa odalarında sâkin el-Hâc Bedreddin nâm kimesne ağzında şâhid olup meclis-i şer'a li-ecli'ş-şehâde hâzırân olan es-Seyyid Halil b. İbrahim ve Sabuncular Hanı'nda sâkin İbrahim b. Abdullah nâm kimesneler istişhâd olunduklarında fi'l-hakîka şâhid-i asl olan mezbûr el-Hâc Bedreddin merkûm Sefer helâkinden üç sene mukaddem menzil-i mahdûd-1 mezbûru sıhhatinde vakf edip süknâsını evvelâ kendüme sonra ile'l-inkırâz evlâdıma ve evlâd-1 evlâdıma ve ba'de'l-inkırâz gallesini Medîne-i Münevvere fukarâsına şart eyledim deyû kirâren benim huzûrumda ikrâr ve beni işhâd edip musırran hâlik olmuşdur ... müsâáade-i süls yoklanmak üzre..." ${ }^{\prime 8}$
}

Sefer'in ne zaman vefat ettiği ve evin vefattan ne kadar sonra satıldığg gibi konular iki belgede de açı olarak yazılmamıştır. Buna karşılık, iki hadisenin de hüccet tarihinden kısa bir süre önce peş peşe gerçekleşmiş olma ihtimali büyüktür. Evin Sefer'in eşi, iki kızı ve iki oğlu tarafından satıldığının belirtilmiş olması ise

97 EHM ŞS, 50, 28/1-29 (Evs Za 1065 / Eylül 1655). Bkz. Ek-10b.

98 EHM ŞS, 50, 28/1-29 (Evs Za 1065 / Eylül 1655). Bkz. Ek-10b. 
ayrıca dikkat çekmektedir. Zira, evin Haremeyn'e ilhak olunduğunu belgeleyen kayıtta, vakfın şart edildiği "evlâd” olarak bu dört çocuğun varlığına dair herhangi bir not düşülmemiş olması, hatta neslin kesildiğinin ifade edilmesi, ailenin akibeti bakımından da ilginç bir durum olarak belirtilmelidir.

\section{Sakyas v. Hacader v. Zirek Vakfi ${ }^{99}$}

Aslen Ermeni olan Sakyas, Balıkesir'de çoğunlukla Ermenilerin yaşadığı Ali Fakih mahallesi sakinlerindendir. ${ }^{100}$ Sakyas, Edirne'de Katır Hanı'nda misafir olarak bulunduğu sırada, sakini olduğu Ali Fakih mahallesindeki mülk evini vakfetmiş ve vakfiyesini Edirne Mahkemesi’nde kayıt alıına aldırmıştır. Vakfının Haremeyn Vakıfları'na ilhak edilmesi şartından dolayı da vakfiyenin bir kopyası Evkaf Müfettişliği defterine işlenmiştir.

Haremeyn şartı: Sakyas'ın tek şartı, vakfının Edirne'deki Haremeyn Vakıfları'na ilhak olunması, sonrasında Haremeyn mütevellisi tarafından kiraya verilmesi ve sağlanan gelirin Medine Müslümanlarına ulaştırılmasıdır. Sakyas, evini gizli hiçbir amaç taşımaksızın (ivazsız ve garezsiz) vakfettiğini beyan ettikten sonra şartını şu şekilde ifade etmektedir:

"Vilâyet-i Anadolu’da Balıkesir kasabasında Ali Fakih mahallesi sükkânından olup mahrûse-i Edirne'de Katır Hanı’nda müsâfiren sâkin Sakyas v. Hacader v. Zirek nâm zimmî mahrûse-i mezbûrede meclis-i şer'-i şerîf-i enverde mahfel-i dîn-i münîf-i ezherde vakf-1 âti'l-beyânı tescîl ve ... menzilimi lâ li-ivaz âcil ve lâ li-garaz âcil vakf-1 sahîh-i şer î ve habs-i sarîh-i merî̀ ile vakf ve habs edip şöyle şart eyledim ki zikr olunan menzil Haremeyn-i Şerîfeyn mütevellîsi yediyle ceret bihi'l-âde ecr-i misli ile îcâr olunup hâsıl olan icâresi mahrûse-i mezbûrede [Edirne'de] Haremeyn-i Şerîfeyn Vakfi'na ilhâk olunup Haremeyn mütevellîsi yediyle Medîne-i Münevvere fukarâsına îsâl oluna”. ${ }^{101}$

Evin hududu Murad v. Sefer, Sefer v. Korgök, Barnak v. Kelbeg, Kirkor v. Simav evleri ve umumi yol ile çevrilidir. Vakfiyenin şahitleri arasında Müslümanlar dışında Avanos v. Surp, Murat v. Mikriç, İsak v. Yusek isimli üç de Ermeni bulunmaktadir.

99 EHM ŞS, 77, 200/2 (Evs L 1101/18-27 Temmuz 1690). Bkz. Ek-11.

1001845 yılı sayımına göre Ali Fakih Mahallesi’nde 50 Ermeni, 13 Rum ve 1 Müslüman hane bulunmaktaydı. Bkz. Tacettin Akkuş, Tanzimat Başlarında Balıkesir Kazası (1840-1845): Demografik Durum (Balıkesir: Zağnos Kültür ve Eğitim Vakfı, 2001), s. 24.

101 EHM ŞS, 77, 200/2 (Evs L 1101/18-27 Temmuz 1690). Bkz. Ek-11. 


\section{Anica bt. Radul v. Angili Vakfi ${ }^{102}$}

Aslen Rum olan Anica bt. Radul, Boğdan voyvodası Mihal'in hanımıdır. ${ }^{103}$ Anica, tescil mütevellisi tayin ettiği Derviş Mustafa b. Ahmed isimli kişi karşısında Beşiktaş Kuruçeşme'de oturduğu evini vakfetmiştir. Söz konusu ev, deniz kenarında bulunmakta ve yalı olarak tabir olunmaktadır. Arkasında tepe (cebel), aynı tarafta Yuğan zimmiye ait ev, bir tarafında Lorenco isimli bir frenk ve diğer tarafında da Dimaki isimli zimmîye ait evler bulunmaktadır. Vakfedilen yalı, hariciye ve dahiliye olmak üzere iki ayrı yapı unsurundan müteşekkildir.

"Hâlâ Boğdan voyvodası olan Mihal Voyvoda’nın zevcesi olup mahrûse-i Galata müzâfâtından kasaba-i Beşiktaş nâhiyesine tâbi' Kuruçeşme demekle ma'rûf nâm karyede sâkine Anica bt. Radul v. Angili nâm nasrâniye tarafından ... vekîl ... olan Mehmed Ağa b. Hüseyin ikrâr ... edip ... hâlâ müvekkil-i mezbûre Anica silk-i mülkünde münselike olduğu karye-i mezkûrede vâki' bir tarafdan Lorenco nâm efrenc mülkü ve bir tarafdan Dimaki nâm zimmî mülkü ve bir tarafdan sâhil-i bahr ve bir tarafdan ba'zan Yuğan nâm zimmî ve ba'zan cebel ila mahdûd hâriciyyede fevkânî dört bâb oda ve dîvânhâne ve kenîf ve tahtânî üç bâb oda ve bir matbah ve bir kiler ve su limanını ve bahçeyi ve derûn-ı bahçede vâki' iki bâb kârgîr oda ve üç bìr-i mầ ve dâhiliyyede fevkânî altı bâb oda ve dîvânhâne ve kenîf ve tahtânî üç bâb oda ve bir matbah ve bir kiler ve iki kenîf ve derdâ tarafında bahçeyi müştemil yalı ta 'bîr olunur mülk menzilini müvekkil-i mezbûr Anica ... vakf ve habs edip"

Şart silsilesi ve Haremeyn şartı: Anica’nın kurduğu vakıf da bir aile vakfıdır. Buna göre şart silsilesinde ilk sırada kendisi vardır. Sonrasında ise çocukları, onların çocukları, azatlı köleleri ve onların çocukları şeklinde silsile devam etmektedir. Neslin kesilmesi, bu tür vakıflardaki genel pratiğe uygun şekilde, şart silsilesinden kopmanın temel gerekçesi olarak belirlenmiştir. Azatlı kölelerden sonra ise yalı, artık geliri Medine fukarasına ulaştırılmak üzere Haremeyn Vakıfları'na ilhak olunacaktır. Yalının tamir masraflarını da "her kişi nöbetinde" yani, tasarruf sırası kendisine geldiğinde karşılayacaktır.

102 EHM ŞS, 110, 9a/1 (13 Z 1130/7 Kasım 1718). Bkz. Ek-12.

103 Boğdan voyvodası Mihal Bey’in 1129/1717 yılında Avusturya-Macaristan’a karşı yürüttüğü askeri mücadelenin anlatıldığı eser ve üzerine yapılmış bir çalışma için bkz. Merve Karaçay Türkal, "18. Yüzyılın İlk Yarısında Eflak ve Boğdan Üzerinde Osmanlı-Avusturya Mücadelesine Dair Anonim Bir Eser: Vakāyi'-i Eflak,” Turkish Studies 12, no. 9 (2017), s. 35-54. 
"süknâsını evvelâ kendüye ba'dehâ evlâdına ve evlâd-ı evlâdına ba'de'l-inkırâz utekâ ve atîkâtına ba'dehüm evlâdlarına ve evlâd-1 evlâd-1 evlâdlarına ve ba'de'linkırâzi'l-kül Medîne-i Münevvere alâ münevverihâ efdalü't-tahiyye fukarâsına şart ve ta'yîn edip ve menzil-i mezkûr mürûr-1 eyyâm ve şühûr-1 kürûr-1 a'vâm ile harâba müşrif olup ta'mîre muhtâc olur ise her kişi nevbetinde ta'mîr ve termîm eyleye deyû şart"

\section{Mihail v. Toma Vakfi ${ }^{104}$}

Osmanlı'nın Rum-Ortodoks tebaasından olan Mihail v. Toma, Şam'da Nasara mahallesinde Kapı sokağında bulunan evini vakfetmiştir. Vakfiyesi Arapça’dır.

Şart silsilesi: Vakıf, öncelikli olarak Şam Meryemiye Kilisesi'nde görevli 3 rahip ve 8 keşişe, onların vefatı sonrasında da arkalarından gelen rahip ve keşişlere, akabinde ise sırasıyla Şam'da yaşayan Rum-Ortodoks ve Müslüman fukaraya şart edilmiştir. Mihail'in çok dikkat çeken bir şartı da, Ortodoksluk mezhebinden ayrılarak Katolikleşen Rumların ${ }^{105}$ bu vakıftan kesinlikle istifade etmemeleri yönündedir. Abdul-Karim Rafeq bu durumu, 'Mihail'in Müslümanlarla kurduğu iyi ilişkilere' bağlamaktaysa da, ${ }^{106}$ Katolik Rumların Mihail tarafından, sapkın olarak görüldüğü veya inanç bakımından Müslümanların Katolik Rumlardan daha yakın konumlandırılmış olduğu fikri makul görünmektedir.

\section{Nikolaki v. Şahin Vakfi ${ }^{107}$}

Aslen Rum olan sarraf Nikolaki Efendi v. Şahin, İstanbul'da Fethiye mahallesinde oturmaktadır. Nikolaki, 20 adet yüzlük mecidiye altınını ve Balat Kiremid mahallesinde Taşmerdivenli isimli yerde mülk olmak üzere yaptırdığı mâ-i lezîz çeşmesini vakfetmiştir.

104 Dımaşk ŞS, 129, 78/169 (10 M 1164/9 Aralık 1750). Bkz. Ek-13. Bu belgeye şu yayın vasıtasıyla ulaştım: Rafeq, "The Establishment of Christian Waqf," s. 165-94.

105 Suriye'de 1723 yılı itibariyle Ortodoksluktan ayrılarak Katolikleşen Rumlar ile Ortodoks Rumlar arasındaki rekabet ve mücadele için bkz. Bruce Masters, Christians and Jews in thi Ottoman Arab World: The Roots of Sectarianism (Cambridge: Cambridge University Press, 2001), s. 89-95; Charles A. Frazee, Catholics and Sultans: The Church and the Ottoman Empire 1453-1923 (Cambridge: Cambridge University Press, 1983), s. 199-213; Hasan Çolak, "Relations Between the Ottoman Central Administration and the Greek Orthodox Patriacrhates of Antioch, Jerusalem and Alexandria: 16th-18th Centuries," (PhD diss. The University of Birmingham, 2012), http://etheses.bham.ac.uk/3968/1/Colak13PhD. pdf (Erişim tarihi: 27.08.2018), s. 87-8, 184-210, 212-4.

106 Rafeq, "The Establishment of Christian Waqf," s. 176-7.

107 EHM ŞS, 784, 95-96 (12 M 1331/22 Aralık 1912). Bkz. Ek-14. 
"İstanbul'da Fethiye mahallesinde Köroğlu sokağında kâin on ve on iki numrolu hânede mütemekkin Devlet-i Aliyye'nin Rum milletinden ve ta'rîf-i şer î î ile muarref Sarraf Nikolaki Efendi v. Şahin Mahkeme-i Evkâf kadı müşâvirliğine mahsûs odada ma'kûd meclis-e şer'-i hatîr-i lâzımü't-tevkîrde zikri âtî vakfa liecli'l-ihkâm ve't-tescîl ve'l-itmâm emrü'l-vakf ve't-tekmîl mütevellî nasb ve ta'yîn eylediği Mahkeme-i mezkûre hademesinden Abdullah Efendi b. Ahmed mahzarında ikrâr-1 sahîh-i şer î ... edip etyab-1 mâl ve enfes-i menâlimden ifrâz ve kemâl-i imtiyâz ile mümtâz eylediğim yirmi aded tâm yüzlük Mecidiye altınıla Balat'da Kiremid mahallesinde Taş Nerdübanlı nâm mahalde vâki' malımdan mebâliğ-i vefîre harc ve sarfla mülküm olmak üzre binâ ve inşâ eylediğim çeşme ve yedimde olup bin üç yüz yirmi yedi senesi Şubatının yirminci günü târih ve bin iki yüz elli dokuz sıra mu âmele numrolu sened-i hâkânî mantûkunca mâlik olduğum kanavât ...? teb iiyyetle ber-vech-i mülkiyet tasarrufla zikr olunan çeşmeye icrâ eylediğim nısf masura mầ-i lezîzden her birini vakf ..."

Şart silsilesi: Fener'de Kanlı Kilise'nin mütevellileri vakfedilen para, Evkaf Nezareti Nukud (Para) Vakıfları idaresinde rehin veya kefil ile helal yoldan faize konulacak ve sağlanan gelir çeşme tamirine harcanacak. Fazla gelen para ile, suyolcu olacak kişiye senelik altmış kuruş verilecek. İbadullah (halk), çeşmeden içecek ve tevliyet, Kanlı Kilise mütevellisine ait olacak. Eğer, zaman içerisinde bu şartlara riayet etmek mümkün olmazsa, vakıf "mutlaka fukarâ-yı Müslimîne sarfoluna" cak. Belgenin ilgili kısmı şöyledir:

“meblağ-1 mevkûf-1 mezkûr Fener'de Kanlı Kilise demekle arîf Rum Kilisesi'nde mezkûr Kilise'nin mütevellîleri bulunan ma'lûmü'l-esâmî kesân taraflarından Evkâf Nezâreti Nukûd-1 Mevkûfe idâresinde rehîn-i kavî veyâhud kefill-i melî ile alâ vechi'l-helâl irbâh olunarak hâsıl olacak ribhile sâlifü̉z-zikr çeşme ta'mîr ve termîm olunup fazlasından suyolcu ta'yîn kılınacak zâta senevî altmış guruş vazîfe verile ve çeşme-i mezkûrdan ibâdullah şürb ü sikāye eyleye ve vakf-1 mezkûrumun tevliyeti sâlifü’l-beyân Kanlı Kilise mütevellîsi bulunan kesâna meşrût ola ve mürûr-1 eyyâm ve şühûr-1 a'vâm ile şart-1 mezkûra ri'âyet müte'azzire olursa vakf-1 mezkûr mutlaka fukarâ-yı müslimîne sarf oluna deyû tayîn-i şurût ve tebyîn-i kuyûd birle...”

\section{Sonuç}

Osmanlı toplumunda gayrimüslimler vakıflarını kurarlarken, şart silsilesini standart ve nötral bir kalıp ile ifade ederek "fukarâ" ibaresini kullanmaktaydılar. Her ne kadar, "fukarâ-yı Müslimîn" tabirini kullananlar var idiyse de, burada da nihai 
hedef, dinleri ne olursa olsun, "fakirler"di. Fakat, İslâm için "manastır fukarâsı", "kilise fukarâsı" her ne ise, Hiristiyan ve Yahudiler için de "Medine fukarâsı" muhtemelen aynı düzlemde anlaşılmaktaydı. Bundan dolayıdır ki, gayrimüslimlerin çok büyük bir bölümü kendi manastır ve kiliselerinin fukarasına, hatta kimi yerlerde doğrudan din adamlarına vakıf kurmuşlardı. Vakıfları incelenen on dört gayrimüslim ise, nihai olarak farklı dinin yani, Müslümanların fukarası veya kurumu için aynı şeyi yapmışlardı. Diğer dindaşlarından çok farklı bir tavır geliştirmiş ve maksatları bakımından ortaklaşmış olmaları, mevzubahis gayrimüslimleri sıra dışı kılmaktaydı.

Ele alınan on dört vakıf arasında Panayot ile Mihail dışındakilerin vakıfları hiçbir şekilde kilise / sinagog irtibatlı değildir. Hatta Kudüs’te yaşayan Âkile, Mansur ve Gâliye vakıflarını doğrudan Kubbetü’s-Sahrâ Camii’ne hasretmişlerdir Bir başka Kudüslü olan Musa b. Davud mülkünü, nihai olarak Kubbetü’s-Sahrâ Camii ve Haremü'l-Halil'e vakfetmişti. Bunun da ötesinde, göreve yeni başlayan her mütevellinin Kubbetü's-Sahrâ ile el-Aksa camilerine bağışta bulunması şartını vakfiyesine eklemişti. Bunlara benzer şekilde Benyamin v. Musa, Sakyas v. Hacader v. Zirek ve Nikolaki v. Şahin herhangi bir bekleme, neslin kesilmesi gibi bir ön şart olmaksızın vakıflarını kısmen veya tamamen Müslümanlara hasretmişlerdi. Diğerlerinde ise, neslin kesilmesi veya hak sahiplerinin vefatları bir ön şart olarak belirlenmişti. ${ }^{108}$

Kudüs Kamame Kilisesi’nde isimleri verilen rahip ve hizmetlilere şart edilen Panayot'un vakfı, sadece bu kimselerin hayatta olmaları ile kayıtlı kılınmıştır. Bu bakımdan Panayot'un vakfı da güçlü bir dinî kaygı ifade etmemektedir. Diğerlerine nazaran yalnızca Mihail v. Toma’nın, Şam’daki Meryemiye Kilisesi rahip ve keşişleri ile Rum Ortodoks fukarası şartlarından dolayı dinî bir kaygı taşıdığı anlaşılmaktadır. Diğer taraftan, Mihail'in Katolik Rumlar'ı kurduğu vakıftan mahrum bıraktığı ve nihai olarak Müslümanların gözetilmesini bildiren şartlar, Ortodoks ve Katolikler arasında var olan derin mezhepsel ayrışmayı vurgularken, kategorik açıdan İslâm dinine olan yakınlığını ifade etmektedir.

Kilise vakıflarının hukuki geçerliği, klasik İslâm hukuku kapsamında masiyet ve kurbet kavramları çerçevesinde vasiyet, miras, vakıfbütünlüğü içinde değerlendirilmişti. Vakıf kurucularının dinlerinin görüşü, fikhın bir kaidesi olarak Osmanlı hukukçuları tarafından da referans sayıldı. Müslümanlar ve gayrimüslimlerin çapraz

108 Tespit edilen belgeler itibariyle, Limon v. Yani ve Halepli Sefer'e ait vakıflar, bütün şartlar yerine geldikten sonra Haremeyn Vakıfları tarafından ilhak edilmiştir. 
olarak birbirlerinin fakirlerine vakıf kurmalarının önünde hukuki açıdan bir engel yoktu. ${ }^{109}$ Osmanlı coğrafyasının diğer bölgelerinde, yoğunluk dereceleri farklı farklı olsa da, Müslüman ve gayrimüslimler birlikte yaşamaktaydılar. Buralarda gayrimüslimler veya Müslümanlar tarafından genele teşmil edilerek "fukarâ" için vakıflar kurulması pek şaşırtıcı olmayabilirdi.

Fakat, bir gayrimüslimin kurduğu vakfı, hassas bir Müslümandan beklenebilecek şekilde, doğrudan ve açıktan Medine fukarasına şart etmesi, fikıhçlar açısından da sıra dışı bir durum olmalıydı. Zira, Müslümanların ikinci kutsal şehirleri olan Medine'de sadece Müslümanlar yaşamaktaydı. Dolayısıyla, başka din mensuplarının bu şehre özel vakıf kurmaları, Osmanlı fakihleri ve toplum nezdinde farklı bir akis bırakmış mıydı? Bu soruyu cevaplandırmak biraz zor. Gayrimüslim vakıfları ile ilgili olarak Osmanlı fikıh literatüründe genellikle, yukarıda değinilen "kurbet" ve "masiyet" boyutu üzerinde durulmakta ve klasik bilgiler tekrar edilmektedir. Toplum tarafında da bu türlü konularla ilgili herhangi bir izdüşüme rastlanmamaktadır.

Meselenin teolojik yanı bir tarafa, bizatihi bu vakıf kurucuları açısından psikolojik durum nasıldı ve hangi motivasyon onları bu türlü bir tercihe yöneltmişti? $\mathrm{Bu}$ on dört gayrimüslim, neden fakir dindaşlarını veya onlar üzerinden kendi mabetlerini düşünmemişlerdi? Örneğin, cemaatine olan bağlllığı vakfiyesinden de açık şekilde anlaşılabilen Karaim Yahudisi Benyamin v. Musa, evinin hemen yanında cemaatine ait sinagog dururken, vakfını neden nihai olarak Medine Müslümanlarına yönlendirmiş ve herhangi bir zaman kaydı düşmeksizin vakfından Haremeyn'e bir pay ayırmıştı? Bu sorulara, elbette, birtakım spekülatif karşılıklar verilebilir. Fakat, durumun objektif nedenlerinin, somut verilere bağlı olarak tespit edilebilmesi biraz zor gibi görünmektedir. Dahası bütün olarak bakıldığında, arka planında inanç motivasyonunun olduğu varsayılan bu tür kararlara, somut verilerin çizdiği sınırların dışına çıkarak yorumlar getirmek, her bakımdan tartışmalı ve sorunlu olacaktır. Kaldı ki Müslüman veya gayrimüslimlerin, sıradan vakıflar kurmalarının arkasında yatan asıl motivasyon kaynağının ne olduğu dahi her zaman bilinememektedir. ${ }^{110}$

109 19. yüzyılda yaşamış Mısırlı hukukçu Muhammed Kadri Paşa’nın hazırladığı kanun kitabında yer alan bir maddeye göre Müslümanlar ve gayrimüslimler, birbirlerinin fukarası için vakıf kurabilirlerdi. Geç döneme ait olan bu madde, Fetâvâ-yı Hindiyye (el-Âlemgîriyye) ve ed-Dürrül-Muhtâr gibi fikıh kitaplarındaki kayıtlardan formüle edilmişti. Bkz. Hoexter, “Charity," s. 148'den naklen Muhammed Kadri Paşa, Kânûnül-adl ve’l-İnsâf li'l-Kazâa alâ Müskilâti'l-Evkâf, 3rd ed., (Cairo: Bulaq, el-Matba'‘'l-Kübrâ el-Emîriyye, 1902), md. 5; Ayrıca bkz. Berki, Vakıflar, s. 65.

110 Singer, İilik Yap Denize At, s. 142; Singer, Osmanlida Hayrseverlik, s. 39. 
Diğer taraftan, az sayıda örneğine rastladığımız ve bu nedenle aykırı duran vakıfların varlığı bizleri, özellikle temelsizliği ortaya konulmuş ${ }^{111}$ bulunan "İslâmlaştırma" (Islamization / confessionalization) veya "baskı ve zorlama" gibi sathî bir gerekçe ve dayanak aramaya itebilir mi? Nitekim bu soruyu, vakıflarını Kubbetü’s-Sahrâ Camii'ne hasreden Âkile, Mansur ve Gâliye örneklerine değinirken A. Cohen sormakta, "baskı ve zorlama" ihtimali üzerinde durmakta, hatta bu vakıfların gerçekte birer aile vakfı olabileceklerini söylemektedir. ${ }^{112}$ Ancak, mevcut kayıtlar böyle bir yorumda bulunmaya imkân vermemektedir. Şöyle ki, sistemin bir baskısı var idiyse, aykırı vakıf sayısının da doğru orantılı olarak çok daha fazla olması beklenirdi. Bazı tarihçilerin provokatif bir tanımlama ile "İslâmlaştırma” dönemi dedikleri 17. yüzyıla ait kayıtların bile çok istisnai kalmış olduğu dikkate alındığında, A. Cohen’in 16. yüzyıl örnekleri üzerinden ihtimalini dile getirdiği bu yoruma katılmak ve yukarıdaki soruya olumlu bir cevap üretmek hiçbir şekilde mümkün görünmemektedir. Zira, her yüzyılda aykırı vakıfların sayısı görünmez derecede azınlıkta kalmakta ve örneklerin tamamı genel temayüle aykırı durmaktadır.

İstanbul'da kurulmuş olanlardan Panayot v. Rafir Vakfı hariç diğerlerine ait belgelerin, Haremeyn Vakıfları'na mahsus bir mahkeme olan Evkâf-ı Hümayun Müfettişliği ${ }^{113}$ sicillerinde kayıtlı bulunması da önemli bir ayrıntı olarak zikredilmelidir. Zira, bu durum Haremeyn vakıflarının bütün süreçlerinin titizlikle takip edildiği, sırası gelenlerin de vakit yitirilmeden ilhak olunduğu veya olunacağına işaret etmektedir.

Sonuç olarak, kültürel bakımdan içiçe geçmiş olan Osmanlı toplumunun birbiri ile sadece ticari ve sosyal ilişki geliştirmediği, katı dinsel bir kategorikleştirme ve ötekileştirme tavrı göstermediği, bunun da ötesinde, sosyal ve ekonomik dayanışmayı, bugünden anlaşılması oldukça zor olan bir kapsayıcılık içerisinde gerçekleştirmiş olduğu, örnekleri verilen aykırı vakıflar üzerinden ileri sürülebilir.

111 Kenan Yıldız, "Doğruluğu Tartışmalı Bir Tartışma: 1660 Yangını İstanbul'un İslâmlaşmasına Etki Etti mi?,” Osmanlı İstanbulu Uluslararası Sempozyum-I (29 Mayıs - 1 Haziran 2013), ed.: Feridun M. Emecen, Emrah Safa Gürkan (İstanbul: İstanbul 29 Mayıs Üniversitesi, 2014), s. 197-242; Yıldız, 1660 İstanbul Yangını, s. 195-234 (özellikle 882 no'lu dipnot).

112 Cohen, Jewish Life under Islam, s. 210.

113801 cilt defterden oluşan Evkâf-1 Hümayun Müfettişliği sicilleri, Haremeyn Müfettişliğine bağlı bir mahkeme idi. Bu Mahkeme’nin teşekkül süreci için bkz. Kenan Yıldız, "Osmanlıda Vakıf Teftişleri ve Vakıf İdaresinin Merkezileşmesi,” (Arapça olarak "Al Rajihi Waqf, Riyad" tarafından yayına hazırlanıyor). 


\section{Aykırı Vakıflar: Osmanlıda Fukarâ-yı Müslimîni de Gözeten Gayrimüslim Vakıfları}

Öz — Bu çalışma, fukarâ-yı Müslimînin yararını da gözeten on dört gayrimüslim (Hıristiyan ve Yahudi) vakfını ele almaktadır. Sayısız gayrimüslim vakfı arasında farklı bir yerde duran "aykırı vakıflar"a, literatürde ilk defa bu çalışma ile ışık tutulmaktadır. Osmanlı döneminde kurulan söz konusu vakıfların beşi hayrî, dokuzu ise ehlî (aile, zürrî) vakıf niteliğindedir. Vakıfların kurucuları şunlardır: Âkile? bt. Harun b. İbrahim (Yahudi), Mansur b. Abdullah (Yahudi), Gâliye bt. Sadun Kallâş̧ (Yahudi), Musa b. Davud b. Yakub (Yahudi), Panayot v. Rafir (Rum), Semha bt. Musa (Yahudi), Benyamin v. Musa (Yahudi), Limon v. Yani (Rum), Halepli Sefer (Ermeni), Sakyas v. Hacader v. Zirek (Ermeni), Anica bt. Radul v. Angili (Rum), Mihail v. Toma (Rum) ve Nikolaki v. Şahin (Rum).

Çalış̧ma iki bölümden oluşmaktadır. Birinci bölümde, tarihsel bir temel oluşturması bakımından gayrimüslimlerin vakıf kurmalarına imkân veren hukuki arka plan ele alınacak, bu vakıfların İslâm ve Osmanlı tarihindeki yeri ve gelişimi retrospektif açıdan incelenecektir. Osmanlıda gayrimüslim vakıflarına hukuki bir zemin kazandıran Şeyhülislâm Ebussuud Efendi’nin görüşleri de bu bağlamda tartı̧ıllacaktır. İkinci bölümde on dört vakıf incelenecek, ilgili vakfiye ve belgelerin kopyaları çalışmanın sonunda verilecektir. Bu vakıflarla ilgili ayrıntıların açıklığa kavuşturulması ile, dinî aidiyetleri ne olursa olsun, tebaa arasında var olan geçişkenlik ve vakıf kültürü gibi konular hakkında bir yoruma ulaşılması umulmaktadır.

Anahtar kelimeler: Vakıf, Aile vakfı, Hayırseverlik, Fukara, Gayrimüslim (Hıristiyan ve Yahudi) vakıfları, Kilise/Manastır vakıfları, Haremeyn vakıfları, Haremeyn fukarası.

\section{Bibliyografya}

\section{Şer'iyye Sicilleri}

Dimaşk

no: 129,134

Evkaf-1 Hümayun Müfettişliği (EHM)

no: $1,7,48,49,50,51,54,77,110,784$

Havass-1 Refia (Eyüb)

no: 45, 90 [Fuat Recep ve dğr., yay. haz., (İstanbul Kadı Sicilleri: Eyüb (Havass-ı Refia) Mahkemesi 90 Numaralı Sicil (H. 1090 - 1091 / M. 1679 - 1680), haz. proje yön. M. Âkif Aydın, ed. Coşkun Yılmaz (İstanbul: İSAM Yay., 2011)]

İstanbul

no: 91, 95, 96, 114

İstanbul Bab

no: 95, 195, 284

Kudüs 
no: $4,5,14,53$

Rumeli Kazaskerliği ve Rumeli Sadareti

no: 57

Üsküdar

no: 163

\section{Yayınlar}

'Abd al-Mu'ti, Husam: "Piety and Profit: The Haramayn Endowments in Egypt (15171814)" Pascale Ghazaleh (ed.), Held in Trust: Waqf in the Islamic World, Cairo - New York: The American University in Cairo Press 2011, s. 41-72.

Akgündüz, Ahmet: İslâm Hukukunda ve Osmanlı Tatbikatında Vakıf Müessesesi., 2. bs. İstanbul: Osmanlı Araştırmaları Vakfı 1996.

Akkuş, Tacettin: Tanzimat Başlarında Balıkesir Kazası (1840-1845): Demografik Durum, Balıkesir: Zağnos Kültür ve Eğitim Vakfı 2001.

Ali Haydar: Tertîbül-Sunûffî Ahkâmi'l-Vukîf, İstanbul: Şirket-i Mürettibiye Matbaası $1337 / 1340$.

Ayalon, Yaron: "Poor Relief in Ottoman Jewish Communities”, Arnold E. Franklin, Roxani Eleni Margariti, Marina Rustow, Uriel Simonsohn (ed.), Jews, Christians and Muslims in Medieval and Early Modern Times: A Festschrift in Honor of Mark R. Cohen, Leiden: Brill 2014, s. 67-82.

Aydın, Bilgin, İlhami Yurdakul, Ayhan Işık, İsmail Kurt, Esra Yıldız: İstanbul Şer iyye Sicilleri Vakfiyeler Katalogu, Ankara: TDV - İSAM Yayınları 2015.

Barkan, Ö. Lütfi - E. Hakkı Ayverdi: İstanbul Vakıfları Tahrîr Defteri, İstanbul: Baha Matbaası 1970.

Barkan, Ö. Lütfi: "Şer'i Miras Hukuku ve Evlatlık Vakıflar”, Abidin Nesimi, Mustafa Şahin, Abdullah Özkan, (haz.), Türkiye’de Toprak Meselesi, İstanbul: Gözlem Yayınları 1980, s. 209-230.

Barnes, John Robert: An Introduction to Religious Foundations in the Ottoman Empire, Leiden: Brill 1986.

Berki, Ali Himmet: Vakıflar, İstanbul: Cihan Kitaphanesi 1940.

Bird, Frederick B.: "A Comparative Study of the Work of Charity in Christianity and Judaism", Journal of Religious Ethics, 10, no. 1 (Florida 1982), s. 144-169.

Bonner, Michael: "Definitions of Poverty and the Rise of the Muslim Urban Poor." Journal of the Royal Asiatic Society, Third Series 6 no: 3 (London 1996), s. 335-344.

Bozkurt, Gülnihal: "İslam Hukukunda Zimmilerin Hukuki Statüleri.” Dokuz Eylül Üniversitesi Hukuk Fakültesi Dergisi, 3 no: 1-4 (İzmir 1987), s. 115-155. 
Buzpınar, Ş. Tufan - Mustafa S. Küçükaşçı: "Haremeyn", TDV İslâm Ansiklopedisi, XVI (İstanbul 1997), s. 153-154.

Cohen, Amnon: A World Within: Jewish Life as Reflected in Muslim Court Documents from the Sijill of Jerusalem (XVIth Century), Part One (Texts), Part Two (Facsimiles), Phliladelphia: University of Pennsylvania Center for Judaic Studies, 1994.

Cohen, Amnon: Jewish Life under Islam: Jerusalem in the Sixteenth Century, Cambridge: Harvard University Press, 1984.

Cohen, Mark R.: "Geniza Documents for the Comparative History of Poverty and Charity", Miriam Frenkel, Yaacov Lev, (ed.), Charity and Giving in Monotheistic Religions, Berlin: Walter de Gruyter 2009, s. 283-341.

Cohen, Mark R.: Poverty and Charity in the Jewish Community of Medieval Egypt, Princeton: Princeton University Press, 2005.

Coşkun, Ali ve dğr. (yay. haz.): 167 Numaralı Muhâsebe-i Vilâyet-i Rûm-İli Defteri (937 / 1530). Ankara: Devlet Arşivleri Genel Müdürlüğü Yay. 2003.

Çizakça, Murat: "Philanthropic Foundations in Roman/Byzantine and Ottoman Empires: A Study in Continuity and Change", Festschrift for Olga Katsiardi (forthcoming).

Çizakça, Murat: İslam Dünyasında Vakıflar, çev. Elif Süreyya Genç, Konya: Karatay Üniversitesi Yayıncilı 2017.

Çolak, Hasan: "Relations Between the Ottoman Central Administration and the Greek Orthodox Patriacrhates of Antioch, Jerusalem and Alexandria: 16th-18th Centuries", PhD diss., The University of Birmingham, 2012. http://etheses.bham.ac.uk/3968/1/ Colak13PhD.pdf, (erişim tarihi: 27.08.2018).

Deguilhem-Schoem, Randi Carolyn: "History of Waqf and Case Studies from Damascus in Late Ottoman and French Mandatory Times", PhD diss., New York University, 1986.

Düzdağ, M. Ertuğrul: Şeyhü̈lislâm Ebussû̂d Efendi Fetvaları: Kanunî Devrinde Osmanlı Hayat, İstanbul: Gonca Yay. 2009.

Eskicioğlu, Osman: "Fakir", TDV İslàm Ansiklopedisi, XII (İstanbul 1995), s. 129-131.

Fayda, Mustafa, Ahmet Yaman, M. Macit Kenanoğlu: "Zimmî”, TDV İslâm Ansiklopedisi, XLIV (İstanbul 2013), s. 428-440.

Fotic, A.: "The Official Explanations for the Confiscation and Sale of Monasteries (churches) and their Estates at the Time of Selim II", Turcica, 24 (Paris 1994), s. 33-54.

Frazee, Charles A.: Catholics and Sultans: The Church and the Ottoman Empire 1453-1923, Cambridge: Cambridge University Press 1983.

Frenkel, Miriam: " "From Now on it is Heqdesh": Jewish Pious Foundation in the Medieval Lands of Islam", Sabine Mohasseb Saliba, (ed.), Les Fondations pieuses waqfs chez les chrétiens et les juifs: Du Moyen Âge à nos jours, Paris: Geuthner 2016, s. 85-99. 
Frenkel, Miriam: “Charity in Jewish Society of the Medieval Mediterranean World”, Miriam Frenkel, Yaacov Lev (ed.), Charity and Giving in Monotheistic Religions, Berlin: Walter de Gruyter 2009, s. 343-364.

Ghazaleh, Pascale: “Introduction: Pious Foundations: From Here to Eternity?", Held in Trust: Waqf in the Islamic World, Cairo - New York: The American University in Cairo Press 2011, s. 1-22.

Gil, Moshe: "Dhimmi Donations and Foundations for Jerusalem (638-1099)", JESHO, 27 no 2 (Leiden 1984), s. 156-174.

Gil, Moshe: “The Earliest Waqf Foundations”, Journal of Near Eastern Studies, 57 no: 2 (Chicago 1998), s. 125-140.

Gil, Moshe: Documents of the Jewish Pious Foundations from the Cairo Geniza, Leiden: Brill 1976.

Ginio, Eyal: "Living on the Margins of Charity: Coping with Poverty in an Ottoman Provincial City", Michael Bonner, Mine Ener, Amy Singer, (eds.), Poverty and Charity in Middle Eastern Contexts, Albany: State University of New York Press 2003, s. 165-184.

Goitein, S. D.: A Mediterranean Society: The Jewish Communities of the Arab World as Portrayed in the Documents of the Cairo Geniza, II, Berkeley: University of California 1971.

Güler, Mustafa: Osmanlı Devlet'inde Haremeyn Vakıfları (XVI. - XVII. Yüzyıllar), İstanbul: TATAV 2002.

Hennigan, Peter C.: The Birth of a Legal Institution: The Formation of the Waqf in ThirdCentury A. H. Hanafì Legal Discourse, Leiden: Brill 2004.

Hoexter, Miriam: "Charity, the Poor, and Distribution of Alms in Ottoman Algiers", Michael Bonner, Mine Ener, Amy Singer (eds.), Poverty and Charity in Middle Eastern Contexts, Albany: State University of New York Press 2003, s. 145-162.

Hoexter, Miriam: "Waqf Studies in the Twentieth Century: The State of the Art", JESHO, 41, 4 (Leiden 1998), s. 474-495.

Imber, Colin: Şeriattan Kanuna: Ebussuudve Osmanlida İslami Hukuk, çev. Murteza Bedir, İstanbul: Tarih Vakfi Yurt Yay. 2004.

İpşirli, Mehmet: "Hikr”, TDV İslâm Ansiklopedisi, XVII (İstanbul 1998), s. 525-526.

Kenanoğlu, M. Macit: "İslam Hukuku ve Birarada Yaşam: -Osmanlı İstanbulu ve Gayrimüslimler-”, Mehmet Fatih Arslan, Muhammed Veysel Bilici, (ed.), Dinsel ve Kültürel Farklılıkların Birarada Yaşaması: İstanbul Tecrübesi (15-17 April 2010), İstanbul: İstanbul Üniversitesi İlahiyat Fakültesi 2010, s. 157-167.

Kermeli, Eugenia: "Ebû's-Su'ûd'a Göre Kilise Vakıfları Osmanlı Hukukundaki Teori ve Pratiği”, çev. Özgen Özcan, Vakıflar Dergisi, 34 (Ankara 2001), s. 165-176.

Kermeli, Eugenia: “Erken Dönem Osmanlı Hukuku ve Gayri Müslimler”, Tevfik Yücedoğru vd., (ed.), Uluslararası Molla Hüsrev Sempozyumu (18-20 Kasım 2011, Bursa) -Bildiriler-, Bursa: 2013, s. 431-447. 
Kolovos, Elias: "Christian Vakifs of Monasteries in the Ottoman Greek Lands from the Fourteenth to Eighteenth Centuries" Sabine Mohasseb Saliba, (ed.), Les Fondations pieuses waqfs chez les chrétiens et les juifs: Du Moyen Âge à nos jours, Paris: Geuthner 2016, s. 103-127.

Köprülü, Fuad: "Vakıf Müessesesinin Hukukî Mahiyeti ve Tarihî Tekâmülü”, Vakıflar Dergisi, II (Ankara 1942), s. 1-35.

Laiou, Sophia: "Diverging Realities of a Christian Vakıf, Sixteenth to Eighteenth Centuries", Turkish Historical Review, 3, (Leiden 2012), s. 1-18.

Lev, Yaacov: Charity, Endowments, and Charitable Institutions in Medieval Islam, Gainesville: University Press of Florida 2005.

Marcus, Abraham: Modernliğ̈in Eşiğinde Bir Osmanlı Şehri: Halep, çev. Mehmet Emin Baş, Küre Yayınları: İstanbul 2013.

Masters, Bruce: Christians and Jews in thi Ottoman Arab World: The Roots of Sectarianism, Cambridge: Cambridge University Press 2001.

Molla Hüsrev: Gurer ve Dürer Tercümesi: İslâm Fıkhı ve Hukûku, trc. Arif Erkan, c. IV, İstanbul: Eser Neşriyat 1980.

Oberauer, Norbert: "Early Doctrines on Waqf Revisited: The Evolution of Islamic Endowment Law in the 2nd Century AH", Islamic Law and Society 20/1-2, (Leiden 2013), s. $1-47$.

Öztürk, Nazif: "Mukataalı Vakıf”, TDV İslâm Ansiklopedisi, XXXI, (İstanbul 2006), s. 132-134.

Pahlitzsch, Johannes: "Christian Pious Foundations as an Element of Continuity Between Late Antiquity and Islam”, Miriam Frenkel, Yaacov Lev (ed.), Charity and Giving in Monotheistic Religions, Berlin: Walter de Gruyter, 2009, s. 125-151.

Pahlitzsch, Johannes: "Christian Waqf in the Early and Classical Islamic Period (Seventh to Twelfth Centuries)", Sabine Mohasseb Saliba, (ed.), Les Fondations pieuses waqfs chez les chrétiens et les juifs: Du Moyen Âge à nos jours, Paris: Geuthner 2016, s. 33-56.

Peri, Oded: Christianity under Islam in Jerusalem: The Question of the Holy Sites in Early Ottoman Times, Leiden: Brill 2001.

Rafeq, Abdul-Karim: "The Establishment of Christian Waqf in the Court Records of Ottoman Damascus: A Comparative Study", Sabine Mohasseb Saliba, (ed.), Les Fondations pieuses waqfs chez les chrétiens et les juifs: Du Moyen Âge à nos jours, Paris: Geuthner 2016, s. 165-194.

Redhouse, Sir James W.: A Turkish and English Lexicon, 2. bs., Beirut: Librairie du Liban 1987.

Richards, Donald S.: "Arabic Documents from the Karaite Community in Cairo", JESHO, 15 no: 1/2 (Leiden 1972), s. 105-162.

Richards, Donald S.: "Documents from Sinai Concerning Mainly Cairene Property", JESHO, 28 no: 3 (Leiden 1985), s. 225-293. 
Richards, Donald S.: "Some Muslim and Christian Documents from Sinai Concerning Christian Property", U. Vermeulen and J. M. F. Van Reeth, (ed.), Law, Christianity and Modernism in Islamic Society. Proceedings of the Eighteenth Congress of the Union Européenne des Arabisants et Islamisants, Katholieke Universiteit Leuven (3-9 September 1996), Leuven: Uitgeverij Peeters 1998, s. 161-170.

Sabra, Adam: Poverty and Charity in Medieval Islam: Memluk Egypt, 1250-1517, Cambridge: Cambridge University Press 2000.

Schacht, Joseph: "Early Doctrines on Waqf”, 60. Doğum Günü Münasebetiyle Fuad Köprülü Armă̆anı, Ankara: Dil ve Tarih Coğrafya Fakültesi 1953, s. 443-452.

Shaham, Ron: "Christian and Jewish Waqf in Palestine During the Late Ottoman Period", Bulletin of the School of Oriental and African Studies, 104 (London 1991), s. 460-472.

Singer, Amy: "Charity's Legacies: A Reconsideration of Ottoman Imperial EndowmentMaking", Michael Bonner, Mine Ener, Amy Singer, (ed.), Poverty and Charity in Middle Eastern Contexts, Albany: State University of New York Press 2003, s. 295-313.

Singer, Amy: İyilik Yap Denize At: Müslüman Toplumlarda Hayırseverlik, çev. Ali Özdamar, İstanbul: Kitap Yayınevi 2012.

Singer, Amy: Osmanlida Hayırseverlik: Kudüste Bir Haseki Sultan İmareti, çev. Dilek Şendil, İstanbul: Tarih Vakfi Yurt Yayınları 2002.

Soykan, T. Tankut: Osmanlı Imparatorlü̆u’nda Gayrimüslimler: Klasik Dönem Osmanlı Hukukunda Gayrimüslimlerin Hukuki Statüsü, İstanbul: Ütopya Kitabevi 2000.

Türkal, Merve Karaçay: “18. Yüzyılın İlk Yarısında Eflak ve Boğdan Üzerinde OsmanlıAvusturya Mücadelesine Dair Anonim Bir Eser: Vakāyi'-i Eflak”, Turkish Studies, 12/9 (İstanbul 2017), s. 35-54.

Uluçam, Abdüsselâm: "Halîl: Haremül-Halîl", Türkiye Diyanet Vakfi İslâm Ansiklopedisi, XV (İstanbul 1997), s. 307-309.

Yediyıldız, Bahaeddin: XVIII. Yüzyılda Türkiye’de VakıfMüessesesi: Bir Sosyal Tarih Incelemesi, Ankara: TTK 2003.

Yıldız, Kenan: "Doğruluğu Tartışmalı Bir Tartışma: 1660 Yangını İstanbul'un İslâmlaşmasına Etki Etti mi?,” Feridun M. Emecen, Emrah Safa Gürkan, (ed.), Osmanlı Ístanbulu Uluslararası Sempozyum-I (29 Mayıs - 1 Haziran 2013), İstanbul: İstanbul 29 Mayıs Üniversitesi, 2014, s. 197-242.

Yıldız, Kenan: "Osmanlıda Vakıf Teftişleri ve Vakıf İdaresinin Merkezileşmesi”, (Arapça olarak "Al Rajihi Waqf, Riyad” tarafindan yayına hazırlanıyor).

Yıldız, Kenan: 1660 Istanbul Yangını ve Etkileri: Vakıflar, Toplum ve Ekonomi, Ankara: TTK 2017.

Yüksel, Hasan: "Vakfiye: Türk ve Osmanlı Tarihi”, TDV İslâm Ansiklopedisi, XLII (İstanbul 2012), s. 467-469. 


\section{EKLER}

Ek-1: Âkile? bt. Harun b. İbrahim'in Vakfiyesi.

Kudüs ŞS, 4, 277, hk. 2057 (8 S 941/19 Ağustos 1534)

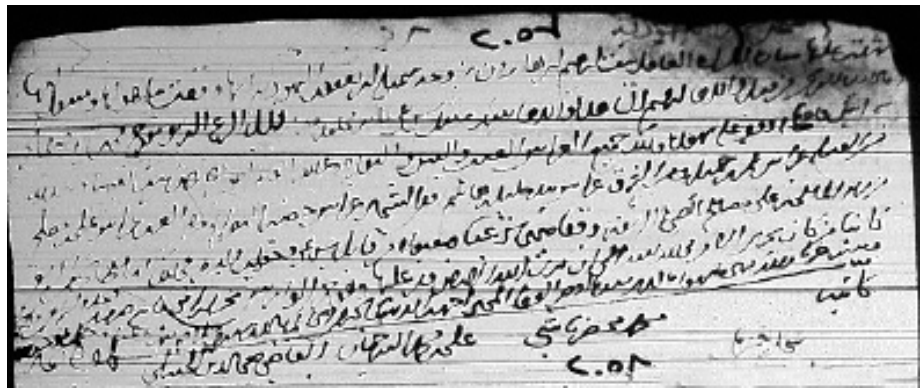

Ek-2: Mansur b. Abdullah Vakfi.

Kudüs ŞS, 5, 82, hk. 360 (18 Z 941/20 Haziran 1535)

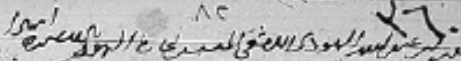

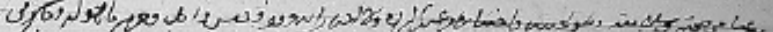

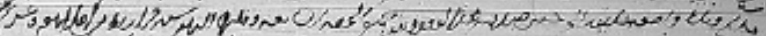

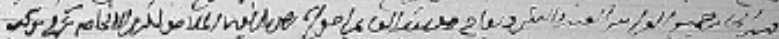

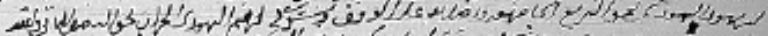

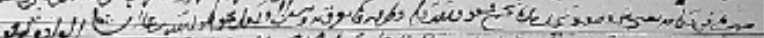

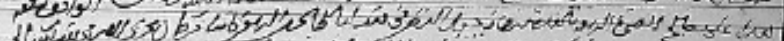

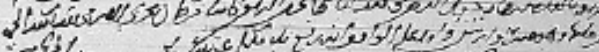

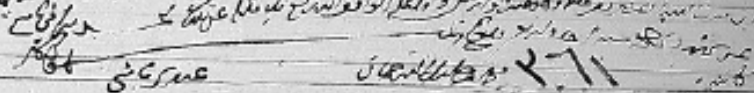

Ek-3: Gâliye bt. Sadun Kallâş Vakfı.

Kudüs ŞS, 5, 98, hk. 429 (7 M 942/8 Temmuz 1535)

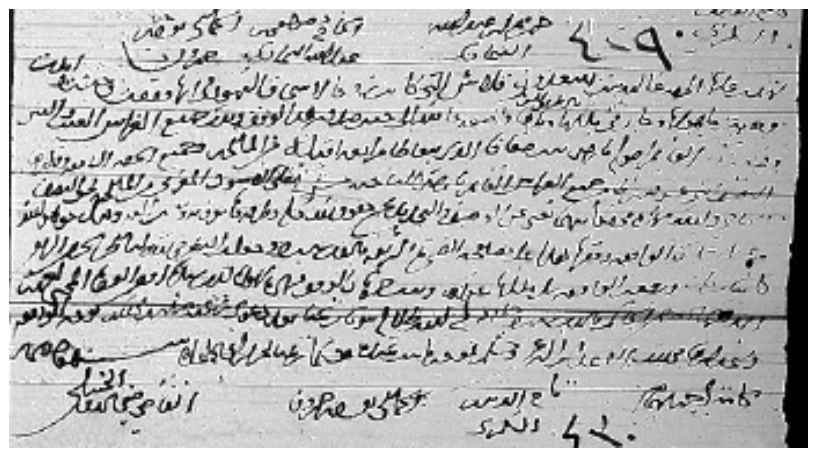


Ek-4: Musa b. Davud b. Yakub Vakfi.

Kudüs ŞS, 14, 461, hk. 1564 (6 S 949/22 Mayıs 1542)

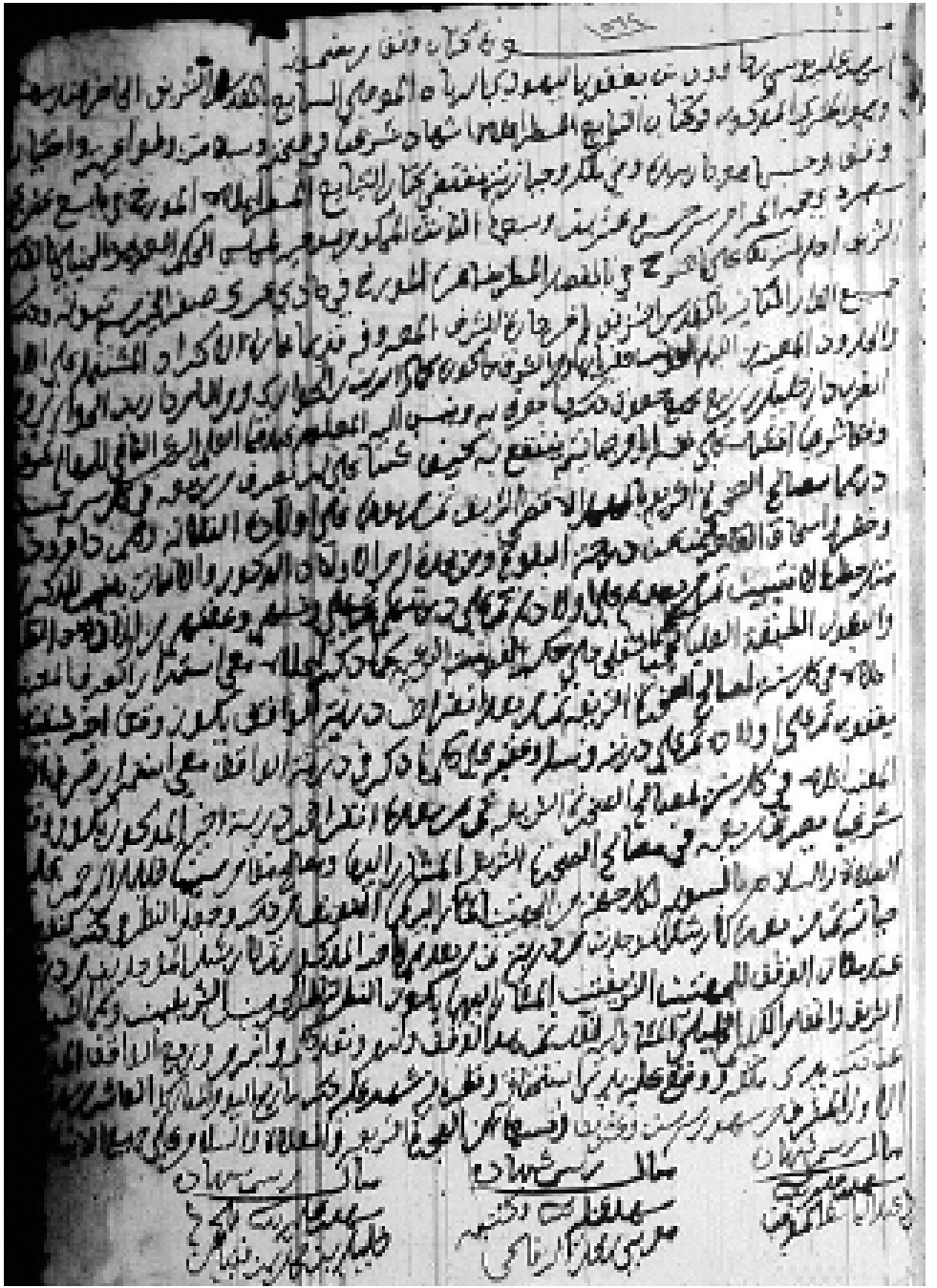


Ek-5: Süleyman b. Davud Vakfı.

Kudüs ŞS, 53 , 339 (12 M 978/11 Haziran 1570)

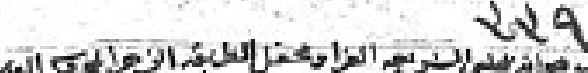

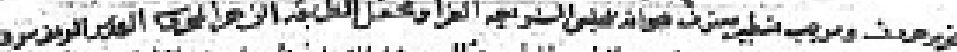

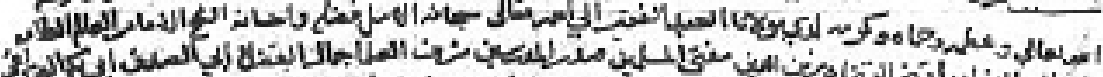

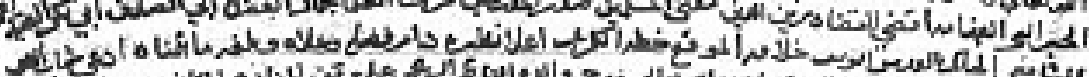

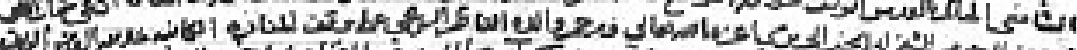

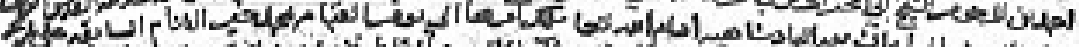

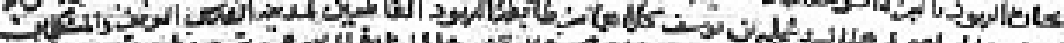

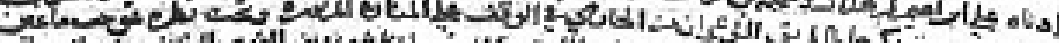

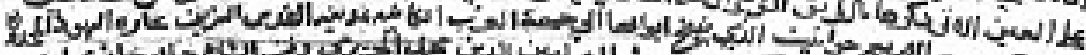

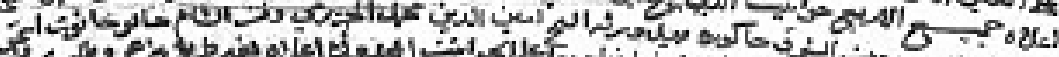

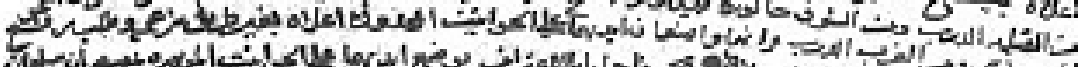
ơ Al

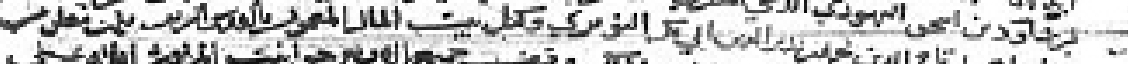
-

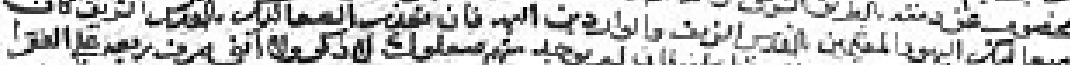

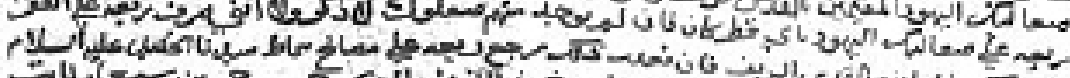

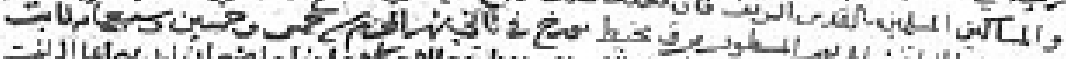

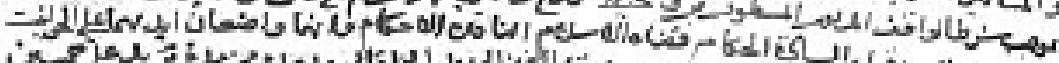
بـ

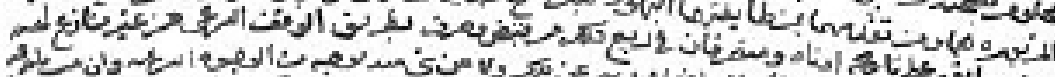
年

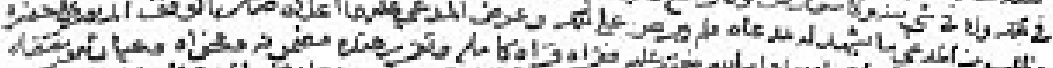

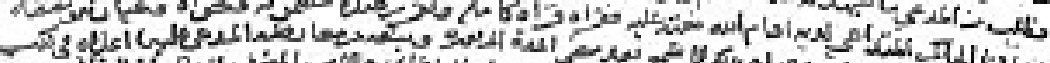

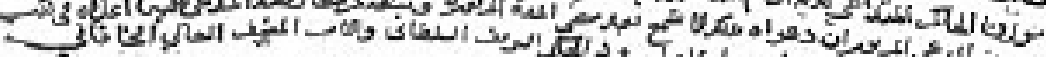

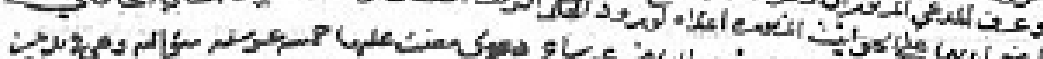

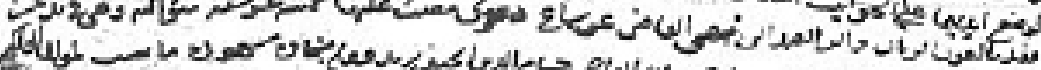

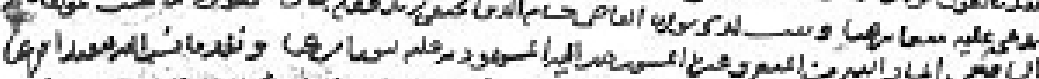
N

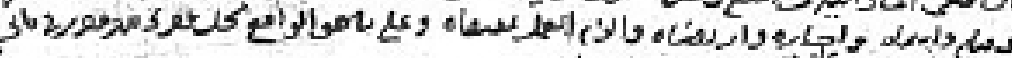

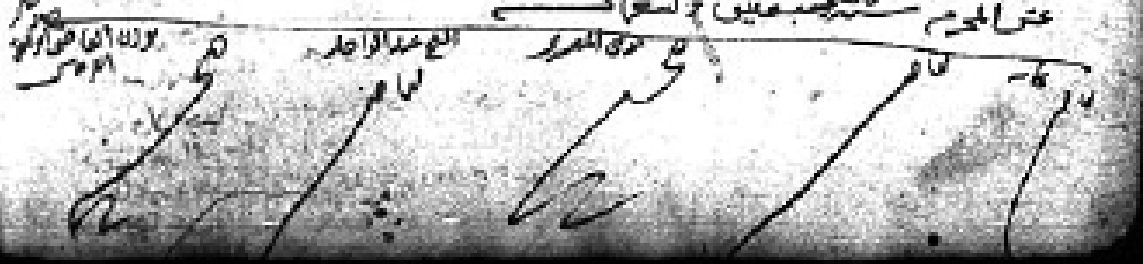


Ek-6: Panayot v. Rafir'in Vakfiyesi.

ÜŞS, 163, 36b/1 (2 M 1040 / 11 Ağustos 1630)

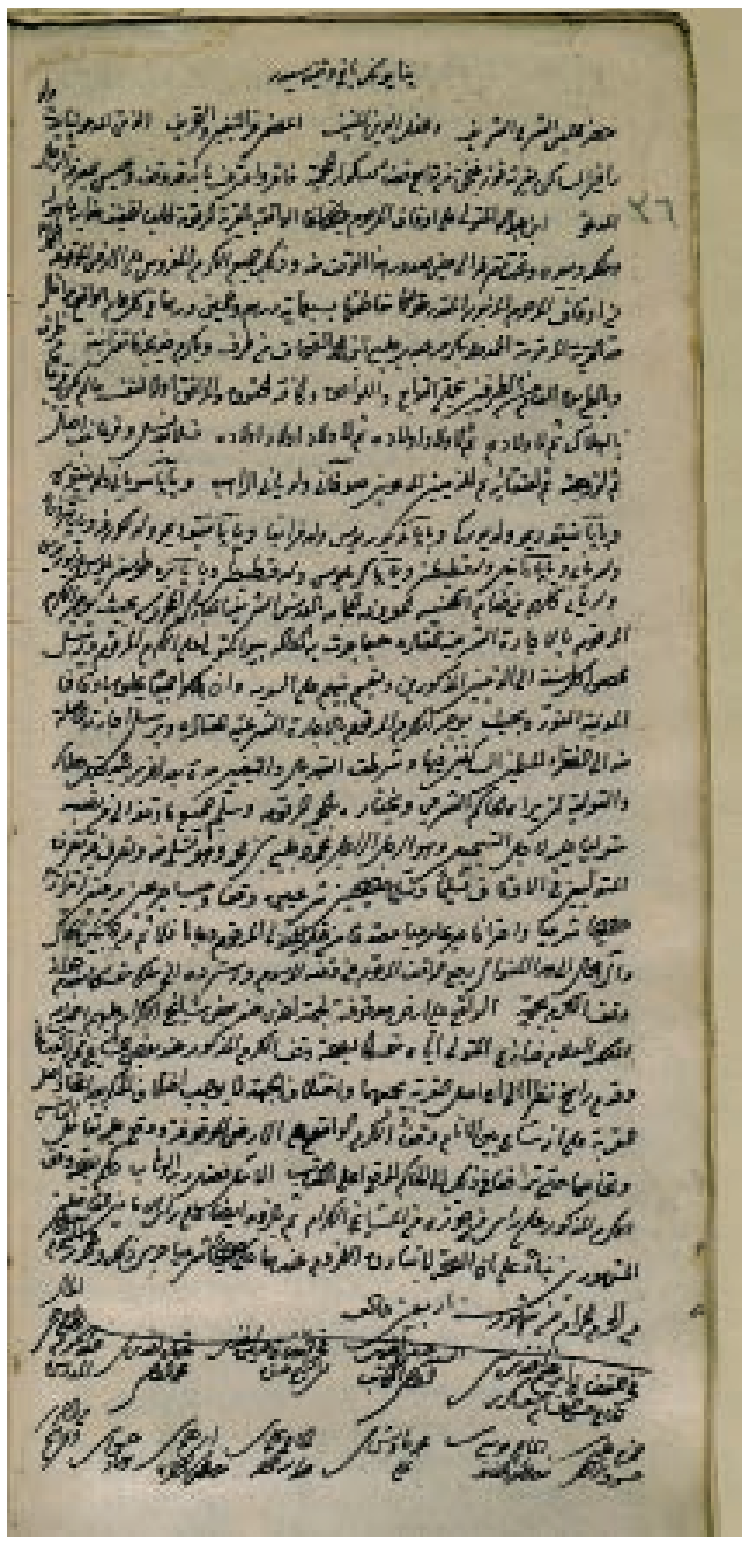


Ek-7: Semha bt. Musa'nın Vakfiyesi.

EHM ŞS, 7, 65a-b (30 N 1040 / 02 Mayıs 1631)

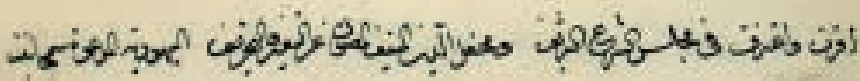

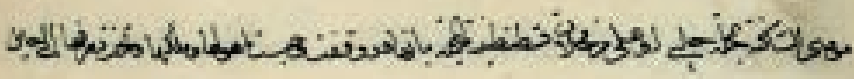

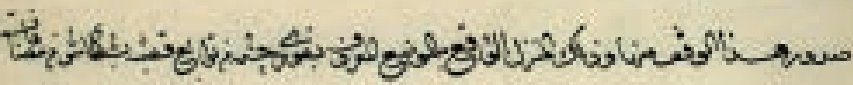

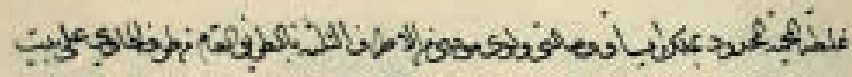

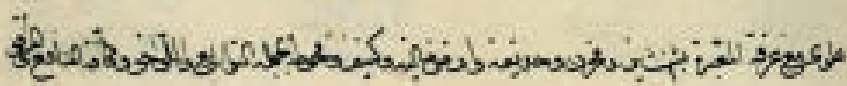

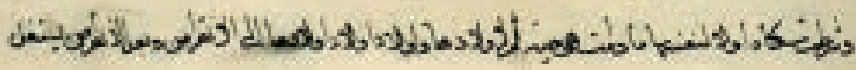

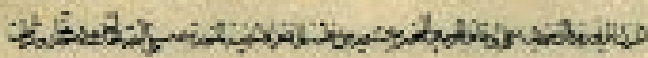

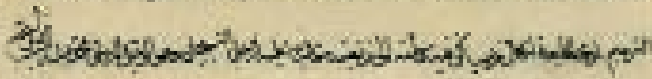

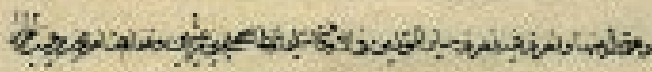
to

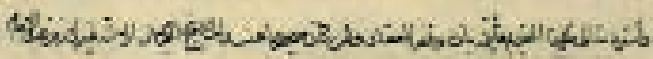

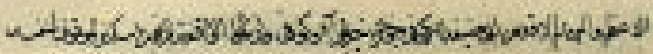
oy

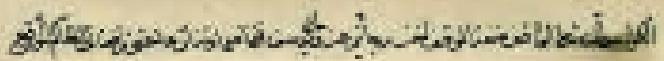

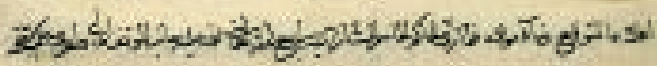

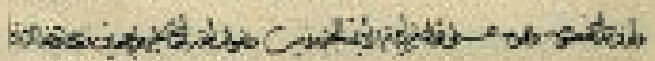

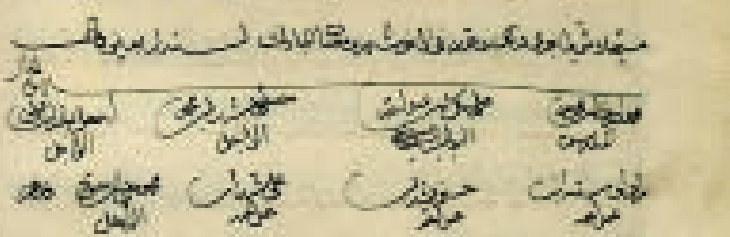


Ek-8: Benyamin v. Musa'nın Vakfiyesi. EHM ŞS, 7, 155a (12 R 1043 / 12 Mart 1634)

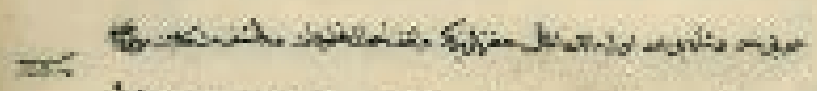

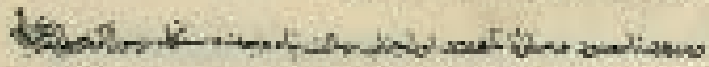

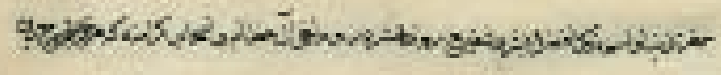

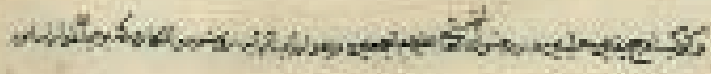

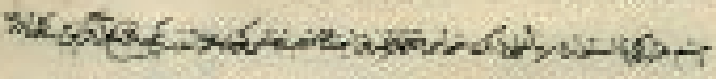

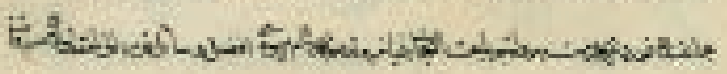

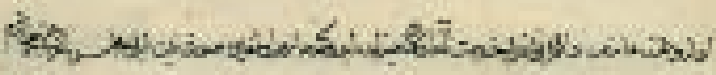

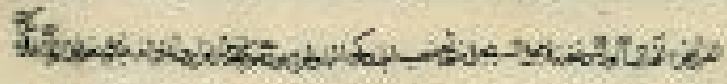

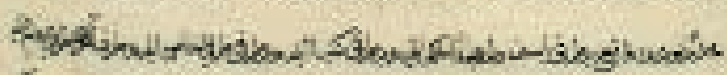
S. 13

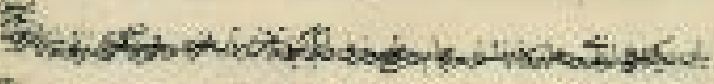
8

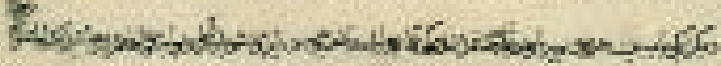

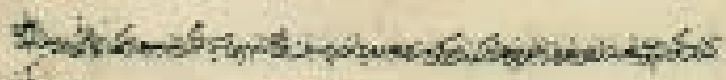

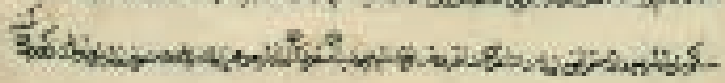


Ek-8: Benyamin v. Musa'nın Vakfiyesi.

EHM ŞS, 7, 155b (12 R 1043 / 12 Mart 1634)

सं

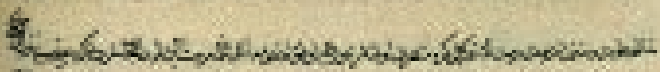
के

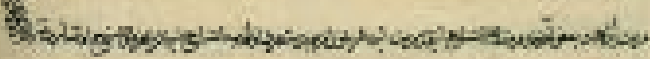

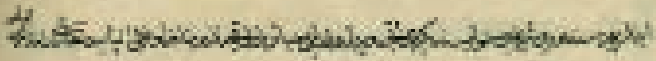

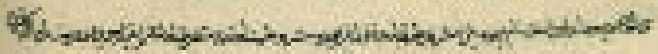
3. $x$

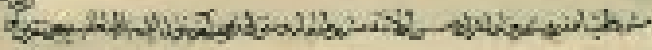

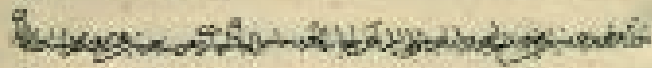

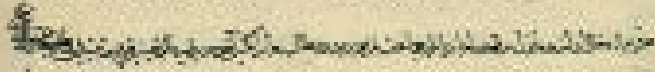

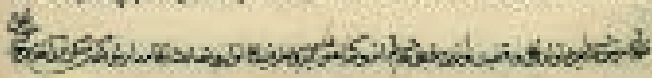

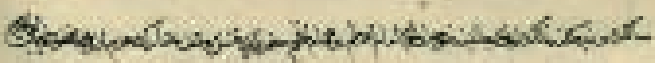

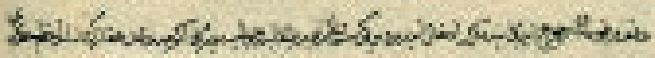

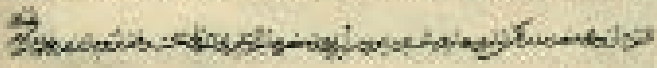

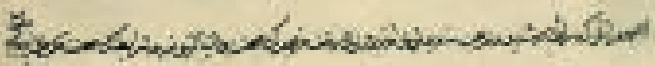

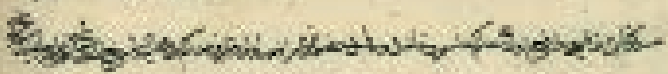

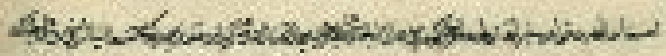

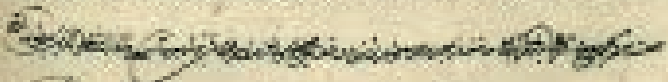


Ek-9: Limon v. Yani vakfiyesi ve diğer belgeler: a) Limon v. Yani’nin vakfiyesi. EHM ŞS, 7, 210b/3 (10 Za 1047 / 26 Mart 1638)

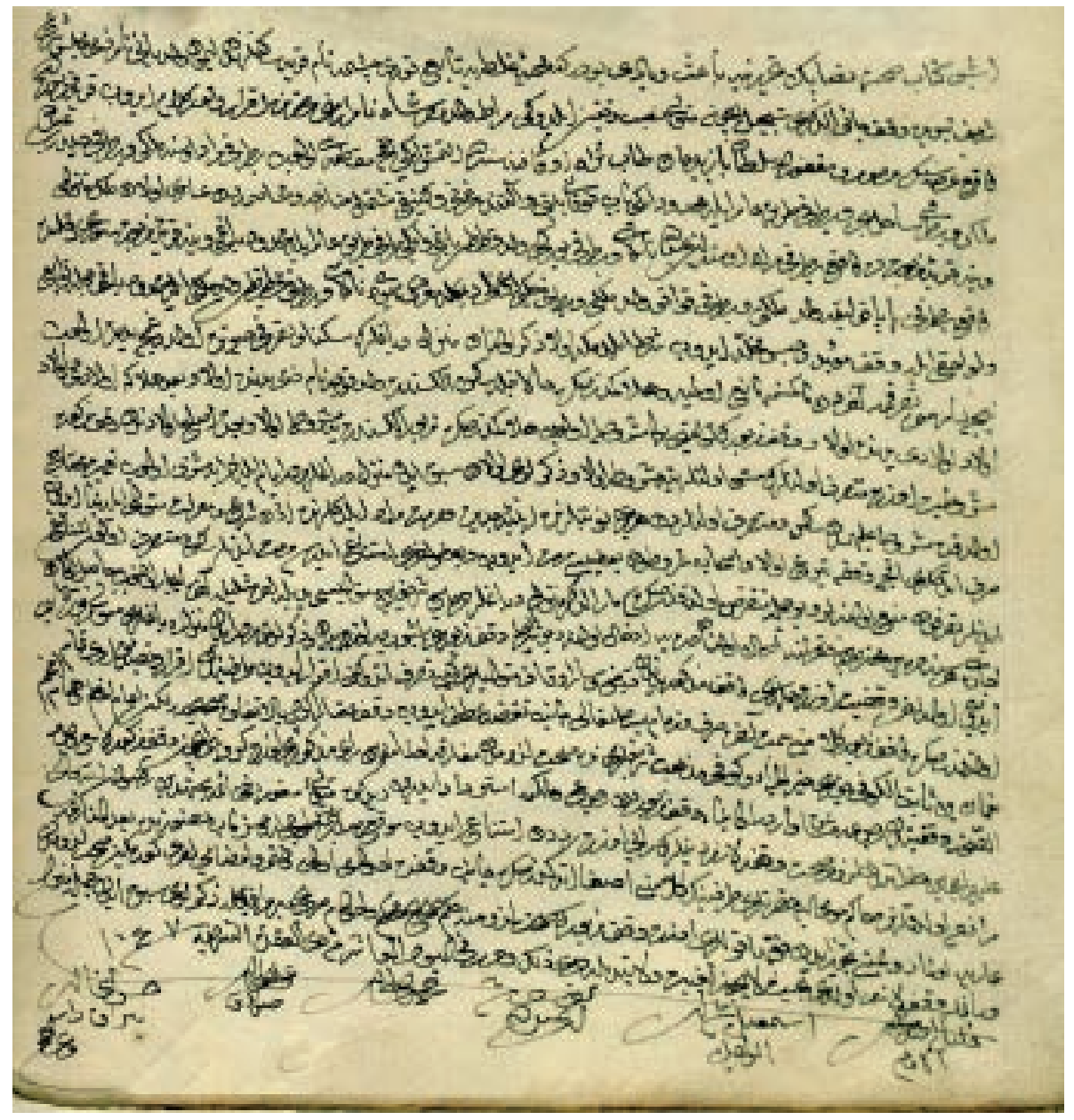


b) Evin Haremeyn Vakfi'na ilhak ve keşif hücceti.

EHM ŞS, 48, 128/1 (18 M 1062 / 31 Aralık 1651)

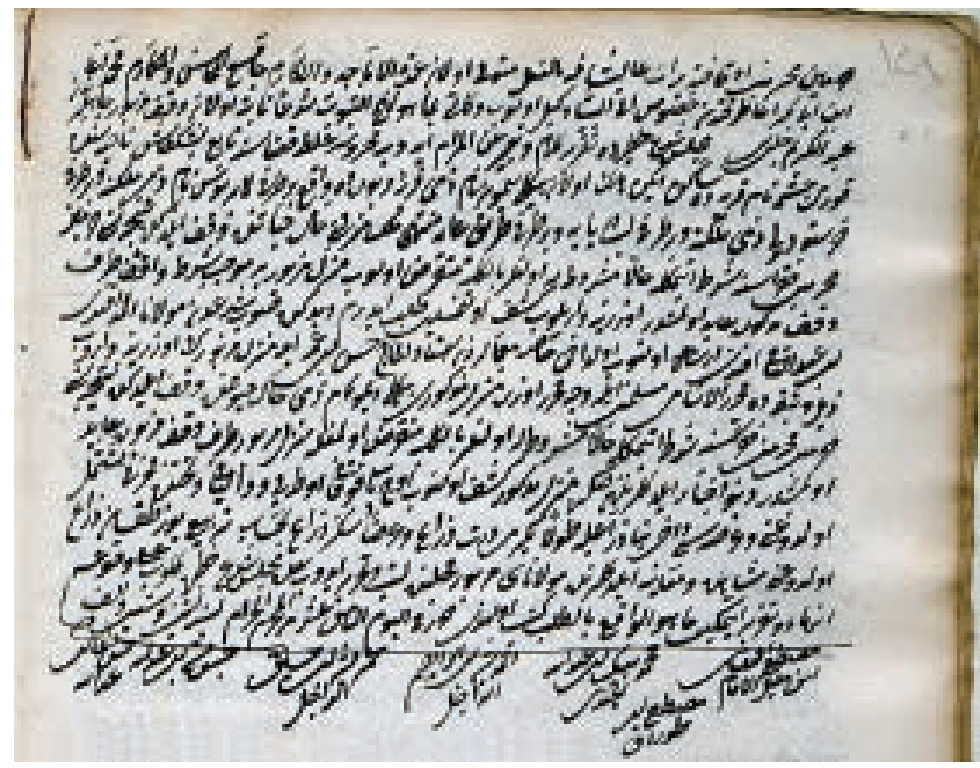

c) Bağların Haremeyn Vakfi'na ilhak ve keşif hüccetleri. EHM ŞS, 48, 127/5 (23 M 1062 / 5 Ocak 1652)

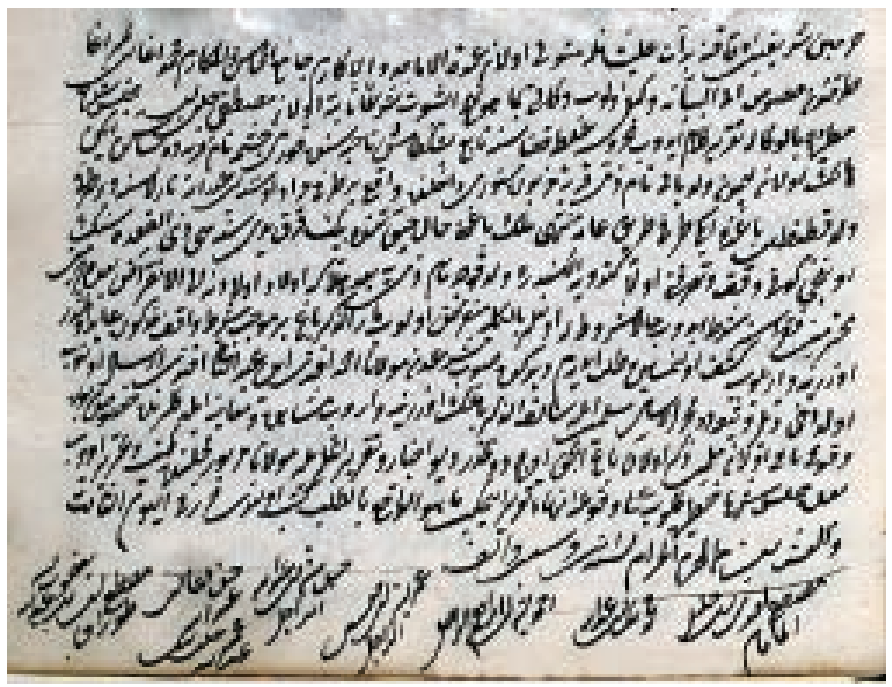


d) Bağların Haremeyn Vakfi'na ilhak ve keşif hüccetleri. EHM ŞS, 48, 128/2 (23 M 1062 / 5 Ocak 1652)
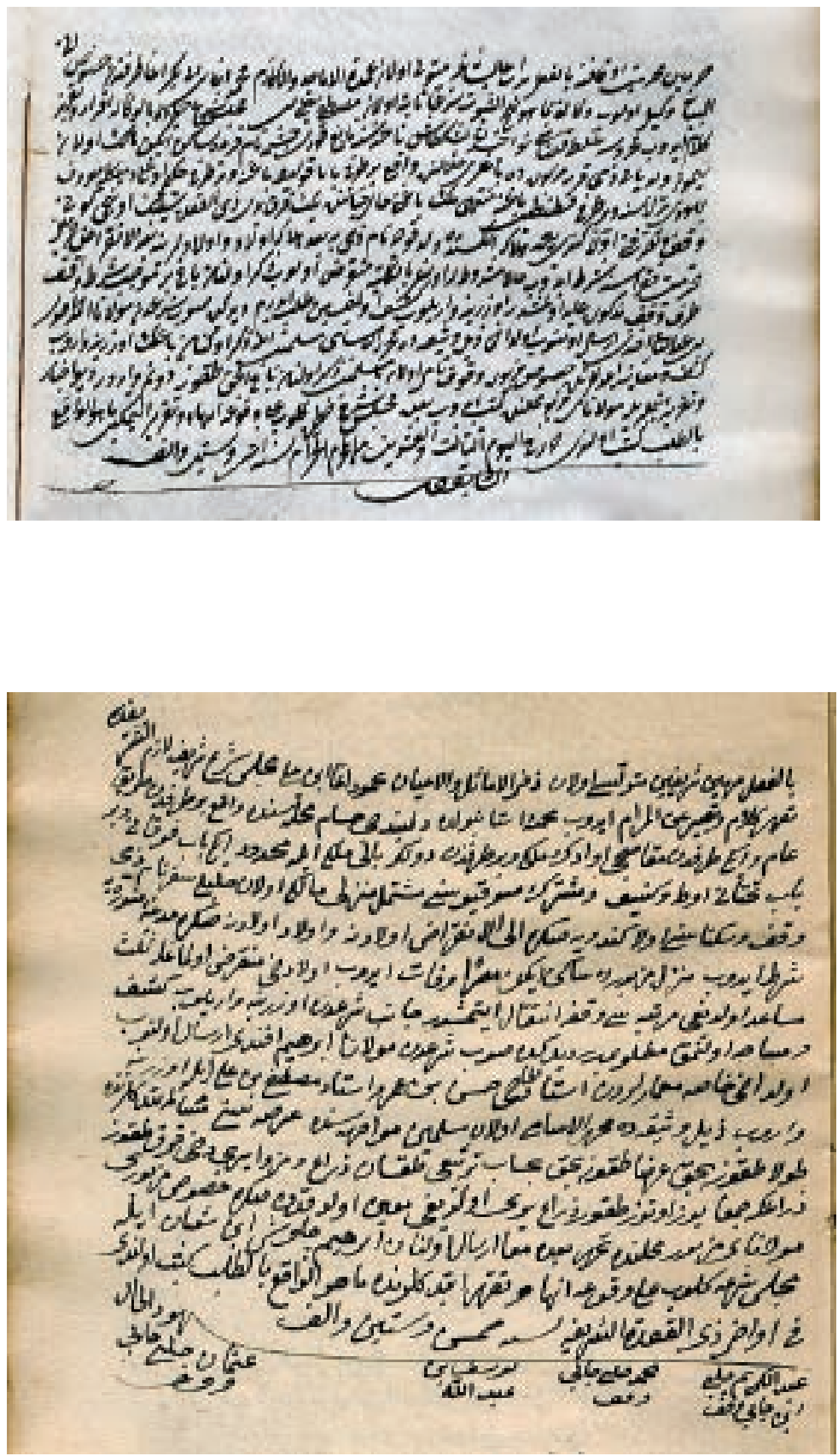
Ek-10: Halepli Sefer Vakfi.
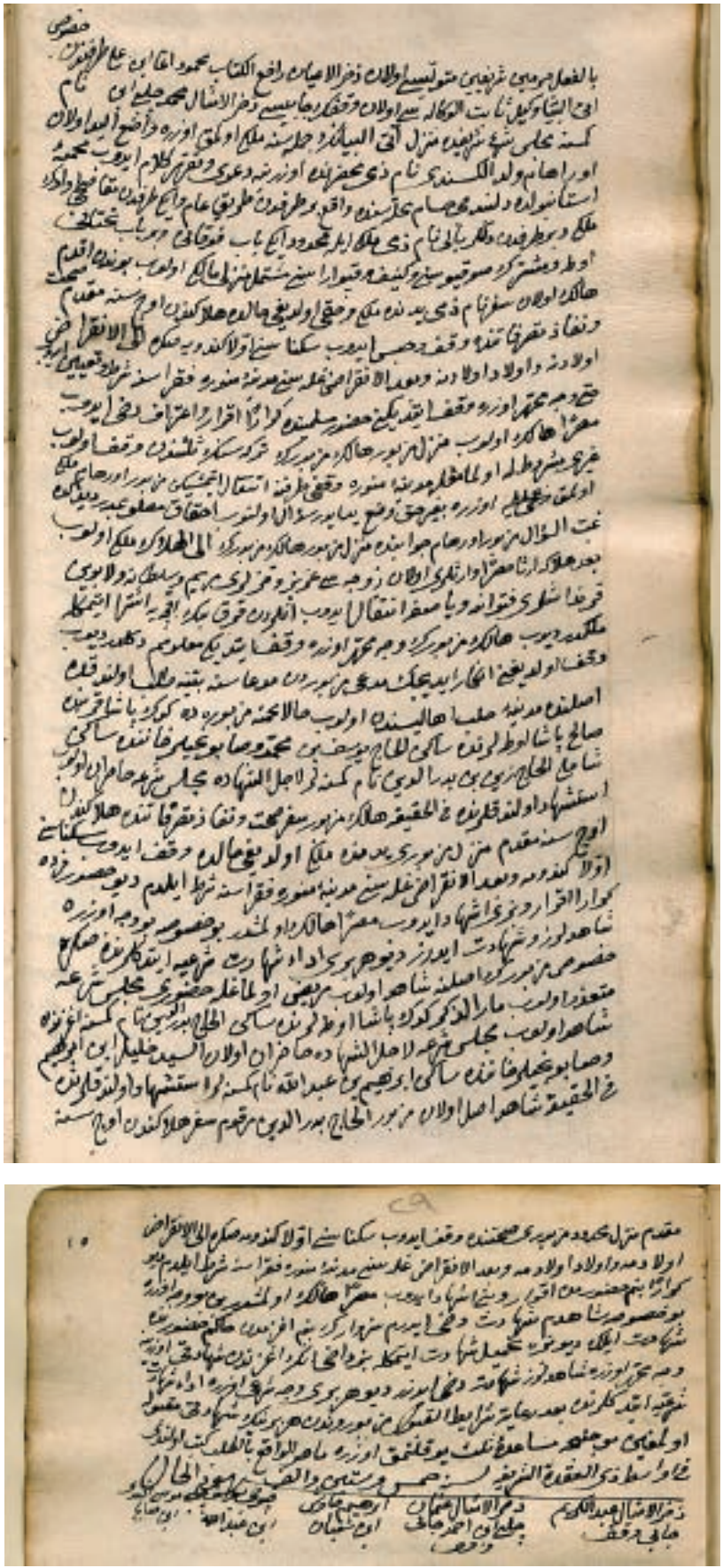
a) Evin Haremeyn Vakfi'na ilhak ve keşif hücceti. EHM ŞS, 50, 27/1 (Evh Za 1065 / Eylül 1655)

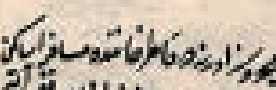

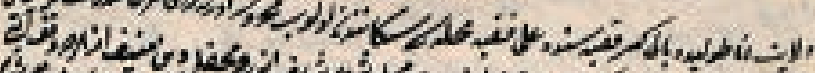
Afids:

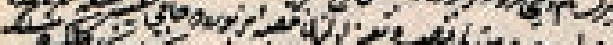
if 10 (1)

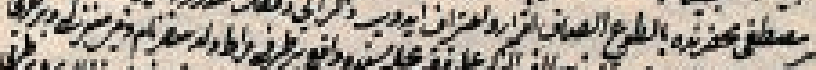
10,4

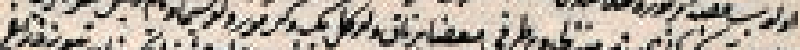
Lis.

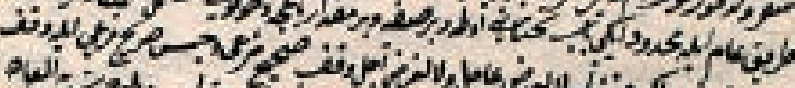

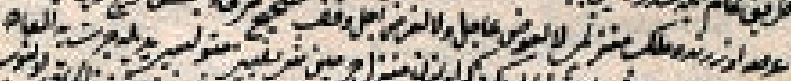

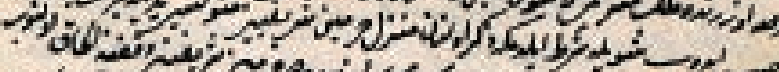

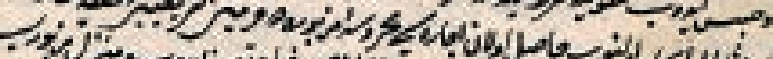

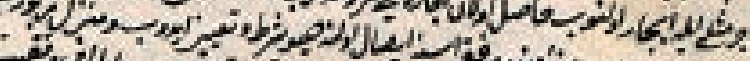

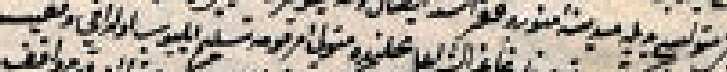
ive -

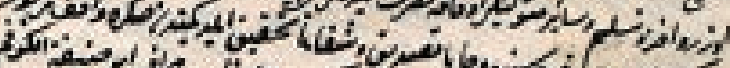

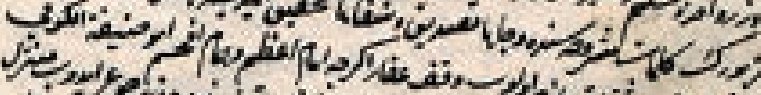

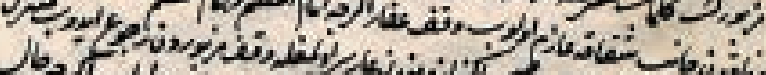

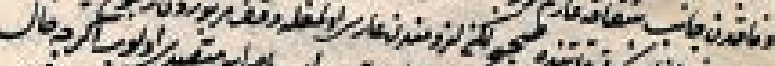
90; i i -

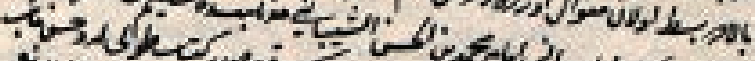

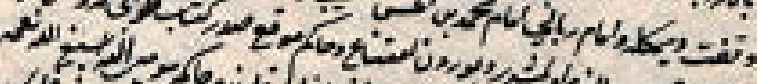

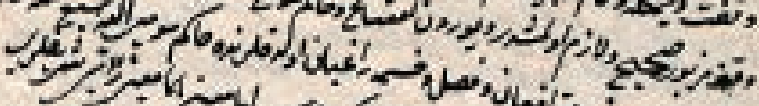

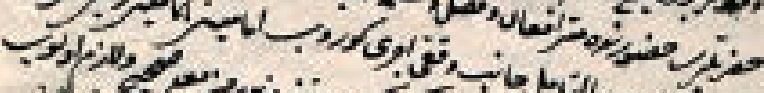

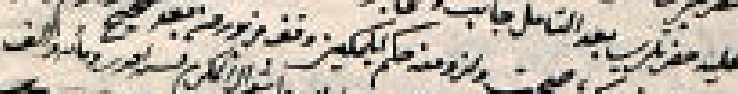
4 S

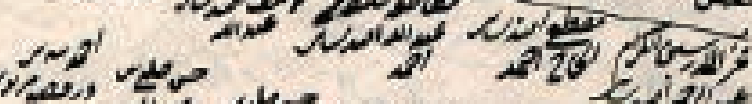
مئ

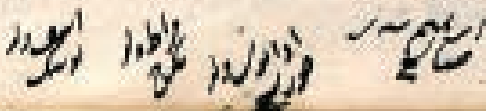


b) Yaşanan ihtilaf üzerine, vakfın sıhhatine dair yapılan inceleme. EHM ŞS, 50, 28/1, 29 (Evs Za 1065 / Eylül 1655)

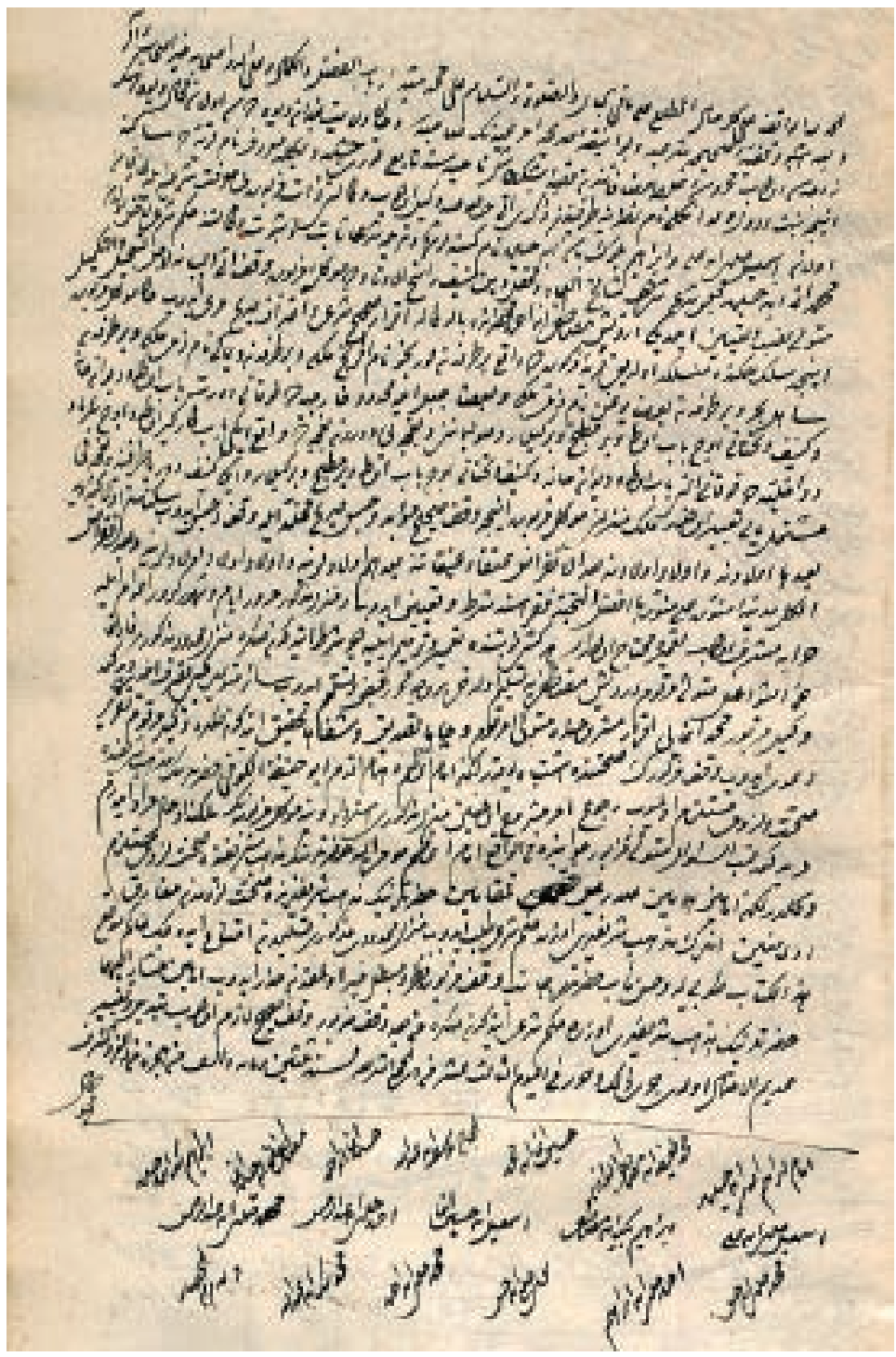


Ek-11: Sakyas v. Hacader v. Zirek Vakfi.

EHM ŞS, 77, 200/2 (Evs L 1101/18-27 Temmuz 1690)

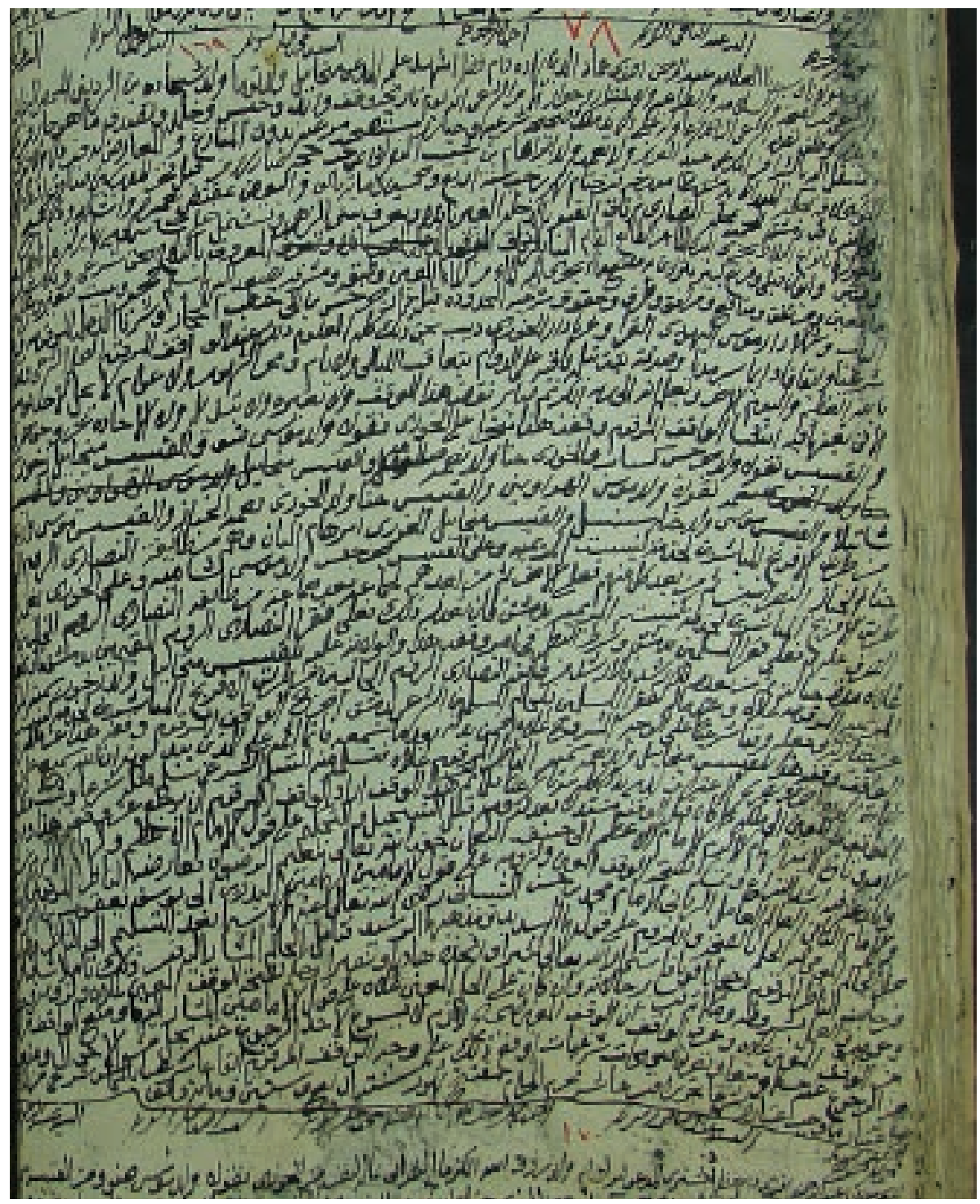


Ek-12: Anica bt. Radul v. Angili Vakfiyesi.

EHM ŞS, 110, 9a/1 (13 Z 1130/7 Kasım 1718)
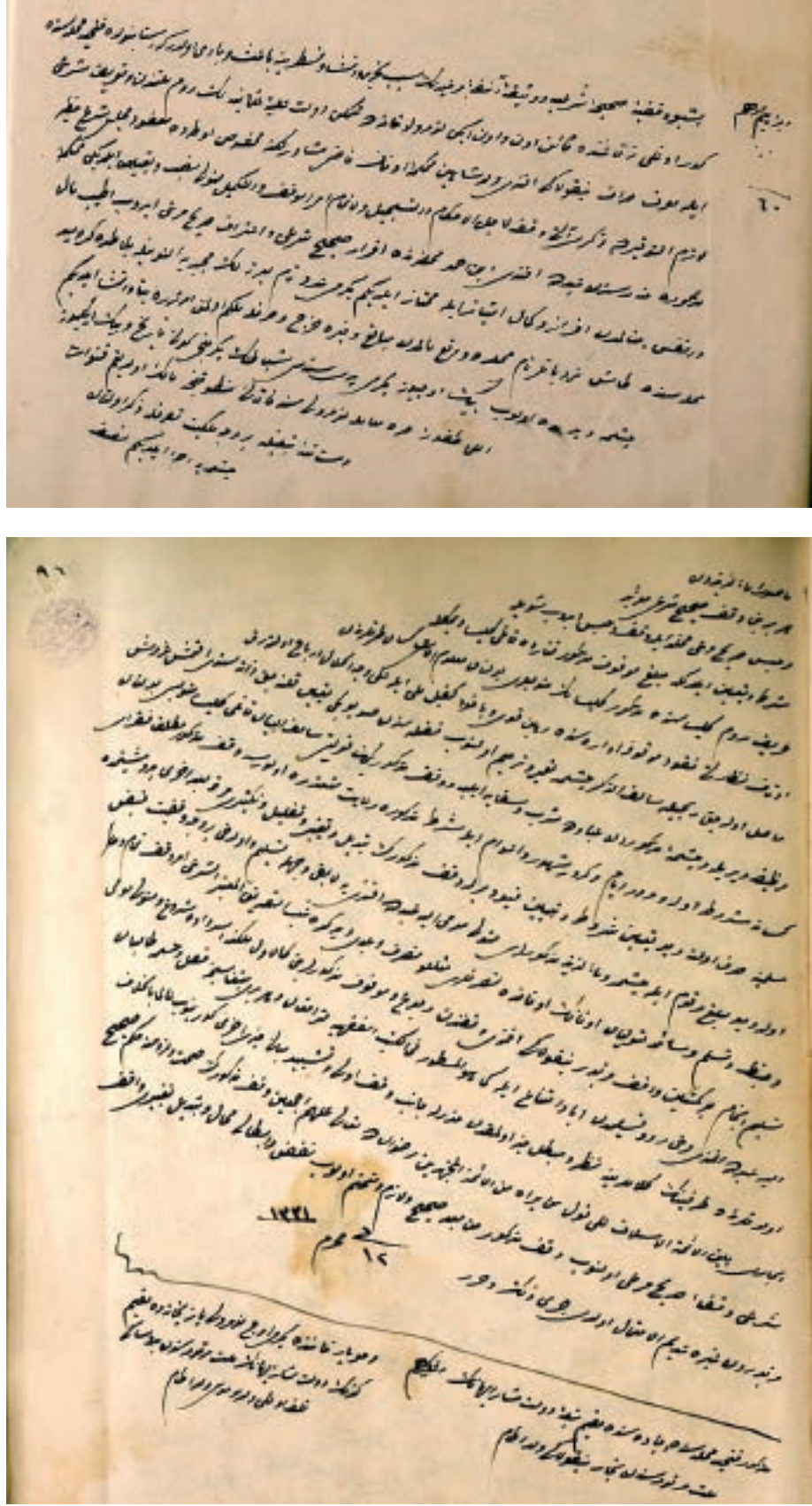